$2 x$

$+2 t^{2} i x$

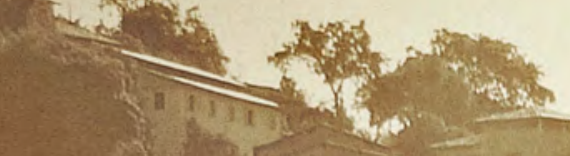

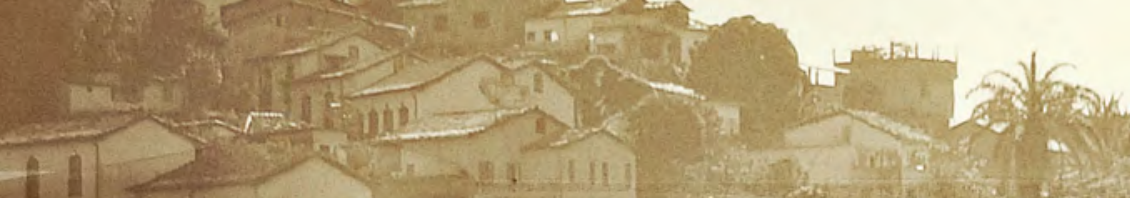

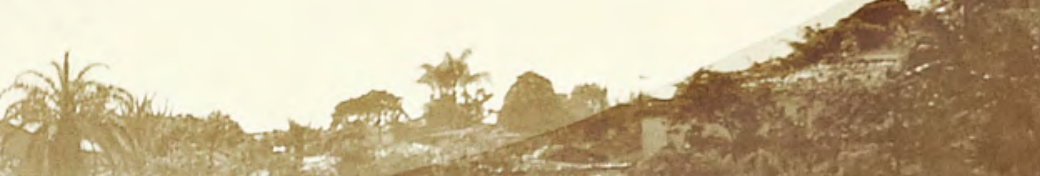

$+4.4$

-

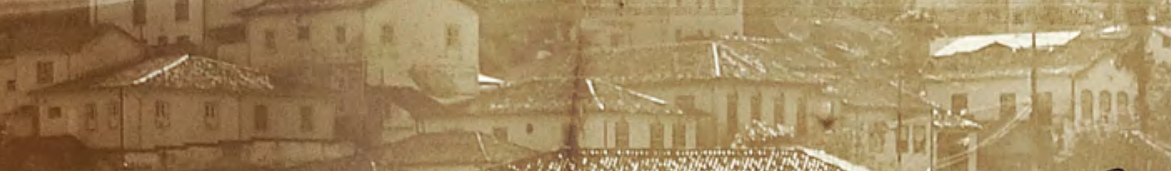

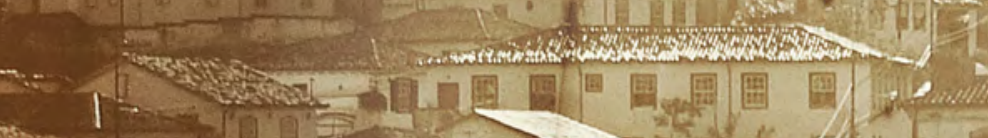

r.t.

THE ED bu

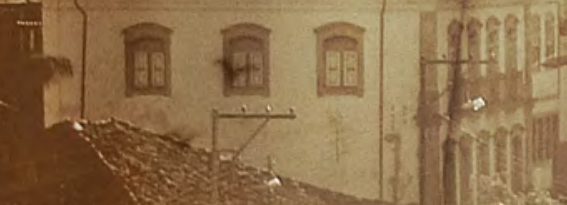

and

$1 .+4 \pi x+5=$

$\therefore$

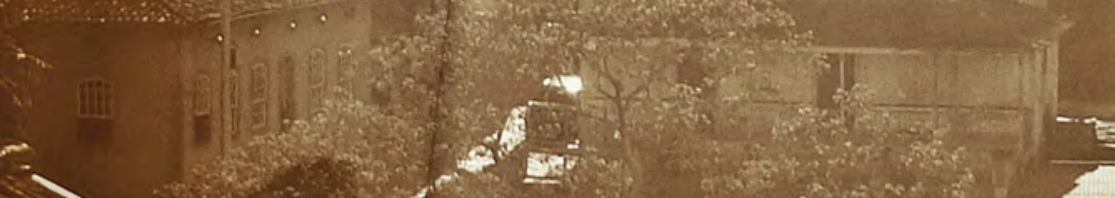

$\rightarrow$

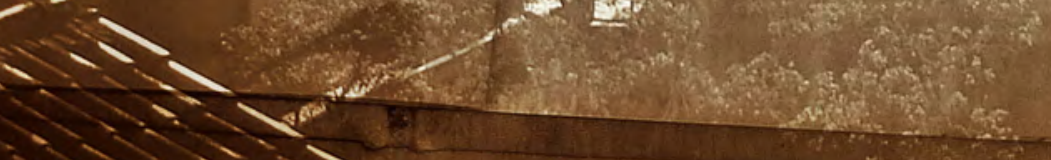

$\lim _{x \rightarrow 3} x^{3}$ 3.

\title{
(4.9)
}

(1)

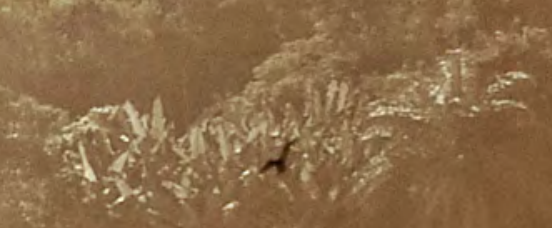

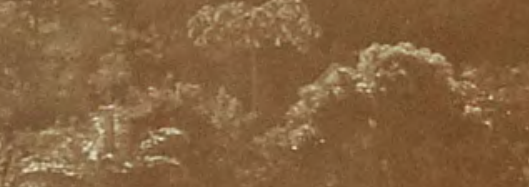
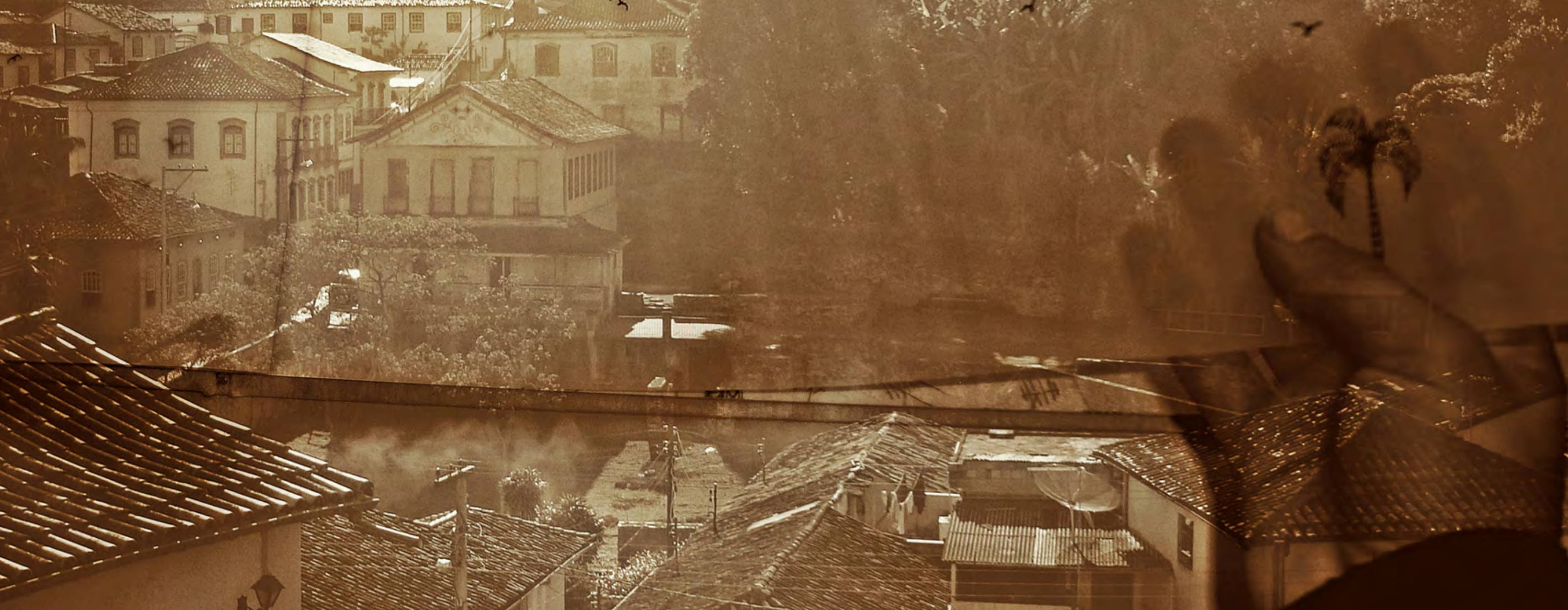
UNIVERSIDADE DE SÃO PAULO

ESCOLA DE COMUNICAÇÕES E ARTES

O Espaço do Papel e o Papel do Espaço

na Construção do Livro de Artista.

KÁTIA FIERA

SÃO PAULO

2015 
UNIVERSIDADE DE SÃO PAULO

ESCOLA DE COMUNICAÇÕES E ARTES

PROGRAMA DE PÓS-GRADUAÇ̃̃O EM ARTES VISUAIS

\section{O Espaço do Papel e o Papel do Espaço na Construção do Livro de Artista.}

KÁTIA FIERA

Dissertação apresentada ao Programa de Pós-Graduação em Artes Visuais

da Escola de Comunicações e Artes da Universidade de São Paulo, como exigência para obtenção do Título de Mestre em Artes. Área de Concentração Poéticas Visuais, sob orientação do Prof. Dr. Hugo Fernando Salinas Fortes Júnior. 
Para Mariazinha,

Que continua cantando no quintal da minha infância

Para Orani,

Que me ensinou a nadar 


\section{Sumário}

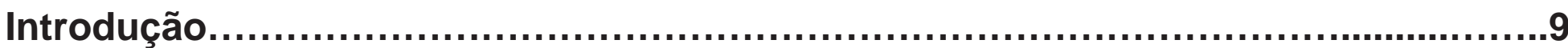

\section{Capítulo 1}

1.1 Narrativa e Sequencialidade no livro.............................................13

1.2 Topografia e Materialidade na Construção.......................................27

Capítulo 2

Arquitetando Páginas, imaginando espaços ou grandes pequenas coisas..........41

Capítulo 3

3.1 O Espaço do Papel e o Papel do Espaço............................................73

3.2 Exposições Móveis ou Campo de Pouso.......................................................89

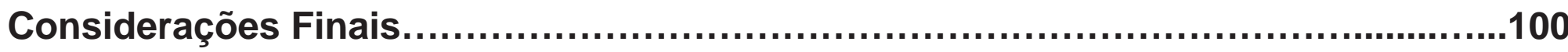

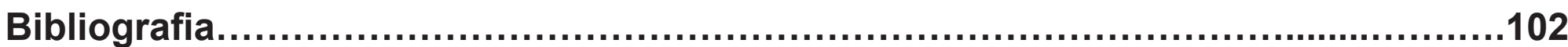




\section{Agradecimentos:}

Ao meu orientador Hugo Fernando Salinas Fortes Júnior, agradeço por todo o auxílio e dedicação a este projeto.

Agradeço ao Programa de Pós-Graduação em Artes Visuais da USP, que por meio da bolsa CAPES, possibilitou a realização desta pesquisa.

Aos professores Marco Buti e Galciani Neves pela valiosa interlocução na fase de qualificação do projeto e aceitarem continuar esta empreitada até a fase final.

À artista Edith Derdyk, que tão generosamente me recebeu em seu atelier e compartilhou suas ideias e processos acerca dos livros e trabalhos de instalação.

Ao Fábio Morais por compartilhar sua bibliotéca e pela troca de ideias.

Ao Leo Gonçalves pela revisão. A Lúcia Rosa, Guilherme Falção, Fernanda Grigolin, Sidney Philocreon, Mônica Rubinho, Estela Vilela e todos os que de alguma maneira fizeram parte deste trabalho.

Aos meus familiares pela paciência nos momentos de ausência durante estes dois anos e meio. Em especial, agradeço a Andréa Xavier Fiera por me encorajar nos momentos de dúvidas e ao Flávio dos Santos Cerqueira, meu companheiro, pelo carinho, apoio e incentivo e por acreditar em mim mais do que eu mesma. 


\section{Resumo}

Esta dissertação é o resultado de uma investigação sobre as relações entre a construção do livro de artista e sua possível presença na produção de instalações artísticas. Busquei compreender de que maneira a utilização do espaço acontece na arquitetura do livro e no espaço da instalação e relacioná-las. Para isso utilizei como corpus trabalhos meus anteriores ao processo deste mestrado, produzidos entre 2002 à 2012, somados a uma série de trabalhos que produzi durante este período e que apresento junto a este texto. Foram realizadas análises de obras de artistas que considero relevantes dentro do quadro em que se insere esta pesquisa.

Palavras-chave: Livros de Artista, espaço, processos de criação, instalação. 


\section{Abstract:}

This work is the result of an investigation on the relationships between the construction of artists' books and their presence in art installations . I aimed to understand and to relate the use of space in the architecture of books and in installations. For this I used my previous work, produced from 2002 to 2012, before the beggining of my master studies, and also a series of works carried out during this period, which I present together with the text. I also analysed works by artists that I consider relevant within the framework in which this research operates.

Keywords: artists' books, space, creation process, installation 


\section{Introdução}

Esta pesquisa trata do livro como espaço para a arte e das relações na construção desse espaço para a produção contemporânea. Trata também de sua presença, formas de apresentação e circulação e do livro como ativador do espaço. Serão abordadas obras que produzi de 2001 até o presente momento, e os trabalhos que desenvolvi até o final da dissertação e que compõem as publicações que acompanham a dissertação em forma de maleta.

Vivemos um momento, em que há uma grande multiplicação das publicações de artista e que o livro como objeto artístico vem sendo cada vez mais valorizado. Há artistas que trabalham o livro como livro-objeto, outros, sua produção e publicação. Porém, identifico em minha produção e na de alguns artistas uma relação entre a construção do livro e o trabalho instalativo. O espaço do livro é explorado como ferramenta de construção da obra e não somente como um espaço bidimensional onde ela é mostrada. Para isso, me alicerço no conceito de abertura proposto por Umberto Eco em Obra Aberta ${ }^{1}$, visto que suas ideias vão ao encontro da produção contemporânea, que pensa os múltiplos como nova forma de circulação da arte. Os múltiplos seriam importantes não só por proporcionar a produção da arte em um momento de repressão, mas por insistir em produzir arte apesar do mercado e criar uma nova circulação desses trabalhos, propondo uma forma mais democrática de acesso à obra e um embate direto com o público. Além de compreender o livro como múltiplo, pretendo analisar as relações da produção de livros de artista com o espaço expositivo e também investigar quais as possibilidades de acesso e apresentação desses trabalhos. Tal análise parte do meu próprio fazer artístico e de que maneira consigo ativar espaços e tornar o trabalho acessível ao público.

1 ECO, Umberto. Obra Aberta. São Paulo: Perspectiva, 1991. 
Em um primeiro momento, irei tratar da construção do livro, sua arquitetura. Como uma referência a essas construções é que utilizo alguns termos do vocabulário da arquitetura para me referir ao plano das páginas. A topografia de suas páginas como a superfície de um terreno, como um espaço geográfico a ser preenchido. Entendo que esse arquitetar se reverbera por toda a minha produção. Para isso encontro o trabalho de outros artistas, que acredito que compartilham das mesmas questões para procurar um maior aprofundamento no tema. Não tratarei aqui de questões de classificação dos trabalhos por entender que o momento é de abertura e não de exclusões.

Os trabalhos em formato livro surgiram em minha produção progressivamente. No início, como cadernos de viagem. O desenho, para mim, é uma forma de guardar as ideias em momentos de trânsito. Uma prática muito comum aos que produzem, por exemplo, gravuras. Colecionar imagens que posteriormente possam ser utilizadas nas placas de impressão. Desenhar é uma atividade comum aos artistas, do renascimento aos dias atuais. Em minha produção, estas imagens foram tomando corpo e as folhas de desenho tornando-se obra. Uma folha após a outra, o trabalho se constrói na tentativa de narrar o percurso e o que acontece fisicamente com quem o percorre, somando aí a fisicalidade do livro e a experiência do folhear, abrir, fechar, percorrer suas páginas. Quanto tempo se leva para cruzar um livro?

De início tratarei das relações entre a narrativa e a sequencialidade existentes no livros, tentando perceber como elas se dão e como essa sequencialidade, que é inerente aos livros, pode ser utilizada em favor da construção da narrativa do trabalho. 
Em seguida, abordo o tema da materialidade, por entender que muitas vezes esta materialidade é matéria para a construção da narrativa. Portanto, os materiais utilizados para a construção dos livros falam por si. Dando sequência ao tema da construção do livro, no segundo capítulo abordo a arquitetura do livro por uma relação de construção do espaço. Primeiramente, o espaço interno do livro e em seguida, talvez como uma consequência dessa experimentação, as relações do espaço do livro e suas possíveis reverberações em outros espaços.

Considero o trabalho ainda em processo. Porém, acredito que tenha conseguido ao menos ter claros os elementos que motivam esta construção. E por perceber que existe muito mais a ser realizado e pesquisado é que tenho a certeza de que o percurso até aqui me guiou ao lugar certo. Espero, que esta dissertação consiga transmitir ao leitor uma parcela do que vi e vivi durante esse caminho

Ao final, trato dos espaços portáteis, visto que a própria dissertação que se apresenta acabou se transformando em espaço tanto de experimentação como de ação e reflexão acerca do tema proposto. Ela abarca, de alguma maneira, todas as atividades que desenvolvi no decorrer do mestrado, aqui existentes em formato de publicações que desenvolvi durante esse período. $\mathrm{E}$ toda a pesquisa e reflexão teórica a partir da prática contida neste texto que chega agora até vocês. Mais do que uma reflexão sobre minha produção, o período do mestrado foi muito fértil, o que pode ser verificado pelo número de publicações que acompanham esta dissertação. Portanto, busquei encontrar referências reais dos trabalhos sem me ater ao volume de citações. 


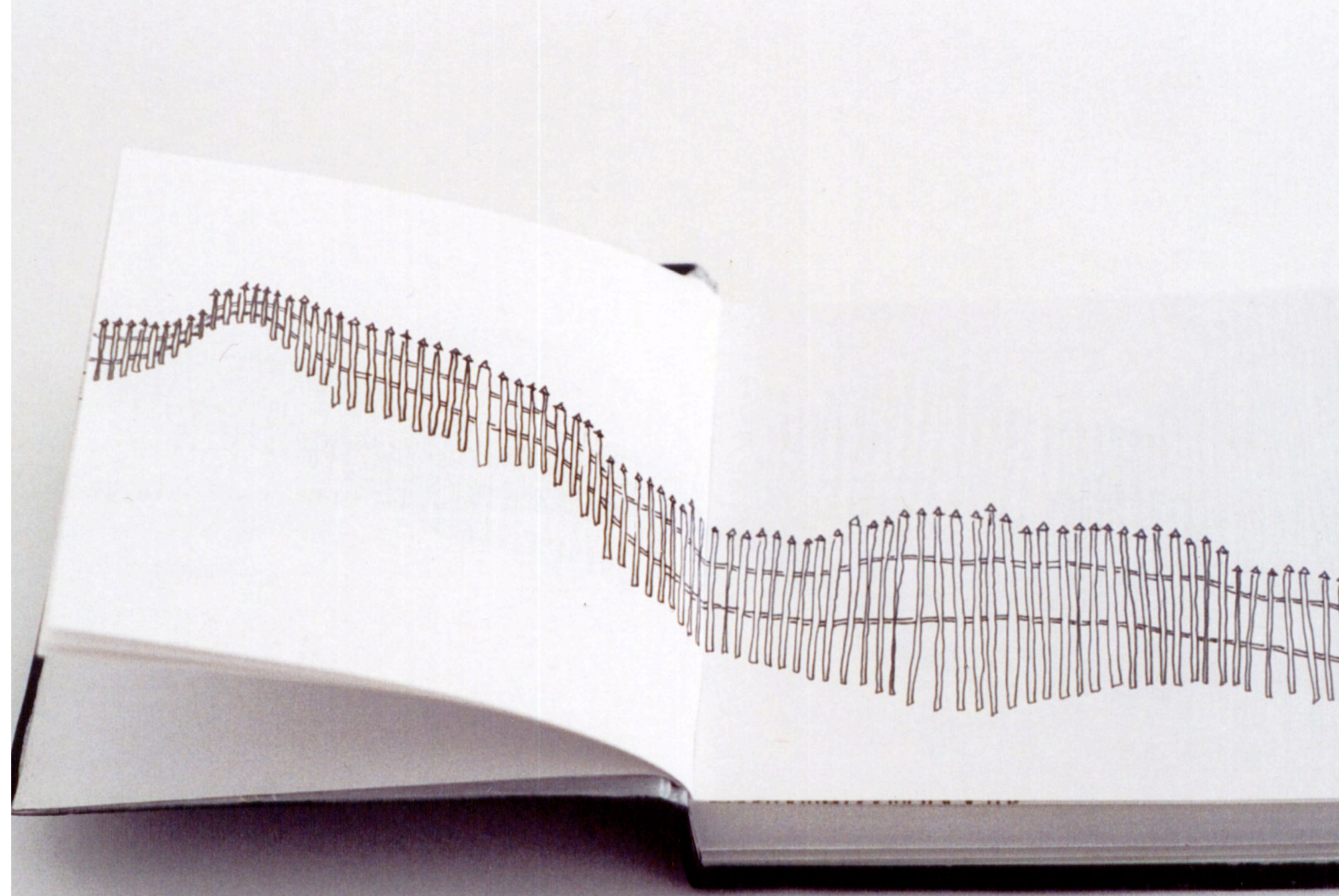




\section{Capítulo 1 \\ Narrativa e Sequencialidade no livro}

"O livro é um lugar assim como o museu é um lugar...”

Christian Boltanski ${ }^{2}$

Assim como um museu ou uma galeria, o livro é um espaço cada vez mais explorado como lugar onde a arte pode acontecer. Tal espaço pode possuir características diversas e as escolhas na construção do trabalho resultam em experiências físicas na des-coberta do objeto livro. Como disse José Emilio Antón, "O livro de artista não é um livro. O livro de artista é uma obra de arte"3. A maneira de tomar contato com sua narrativa e de manipulá-lo ativa a percepção e completa a sua fruição. Existem diversas maneiras de se construir o livro e pretendo, por meio delas, abordar assuntos que acredito importantes para compreender minha própria trajetória como artista até o momento.

A ideia de sequencialidade que o livro carrega foi um dos primeiros elementos de construção que utilizei e que me guiaram em direção a uma produção que, em princípio não pretendia ser livro, visto que não tem raízes na literatura. Porém, com o passar do tempo, acabei percebendo que se tratavam de livros em uma concepção mais ampla, uma visão que já era proposta por Marcel Duchamp e outros artistas das vanguardas da arte postal e do livro de artista. Mas para começar a falar de sequencialidade necessito voltar um tanto no tempo e recorrer a um antigo caderno de viagem produzido no Brasil de 1816.

2 PANEK, Bernardette. Pós: Belo Horizonte, v. 2, n. 3, p. 137 - mai. 2012.

3 ANTÓN, José Emilio. El libro de artista, el libro como obra (Catálogo de exposición). Munique: Instituto Cervantes de Munique, 1994. 
O fac-símile do "Caderno de Viagem" de Jean-Baptiste Debret é um livro que imediatamente me chamou atenção. O livro possui o formato paisagem e o interessante é que nele praticamente não há representação de paisagem e sim figuras humanas. O artista se utiliza do formato para nos dar a impressão de que seus personagens caminham por entre as páginas. Os personagens surgem e somem, como se as páginas fossem a própria paisagem. Viramos as páginas e é como se percorrêssemos esta paisagem um dia após o outro. Viajamos com o artista até o final, pelas páginas do livro.

O artista, por sua situação de transitoriedade, coloca no caderno algo além de um desenho de observação. Parece querer transmitir uma sensação especial, de amplidão, o que fica mais evidente ainda no formato extenso de paisagem que se amplia à medida em que abrimos as páginas e a paisagem continua. E a própria transitoriedade é de alguma maneira representada por meio dos personagens que aparecem a lápis, se transformam em aquarelas e novamente se esvaem em lápis, como se sumissem na próxima esquina.

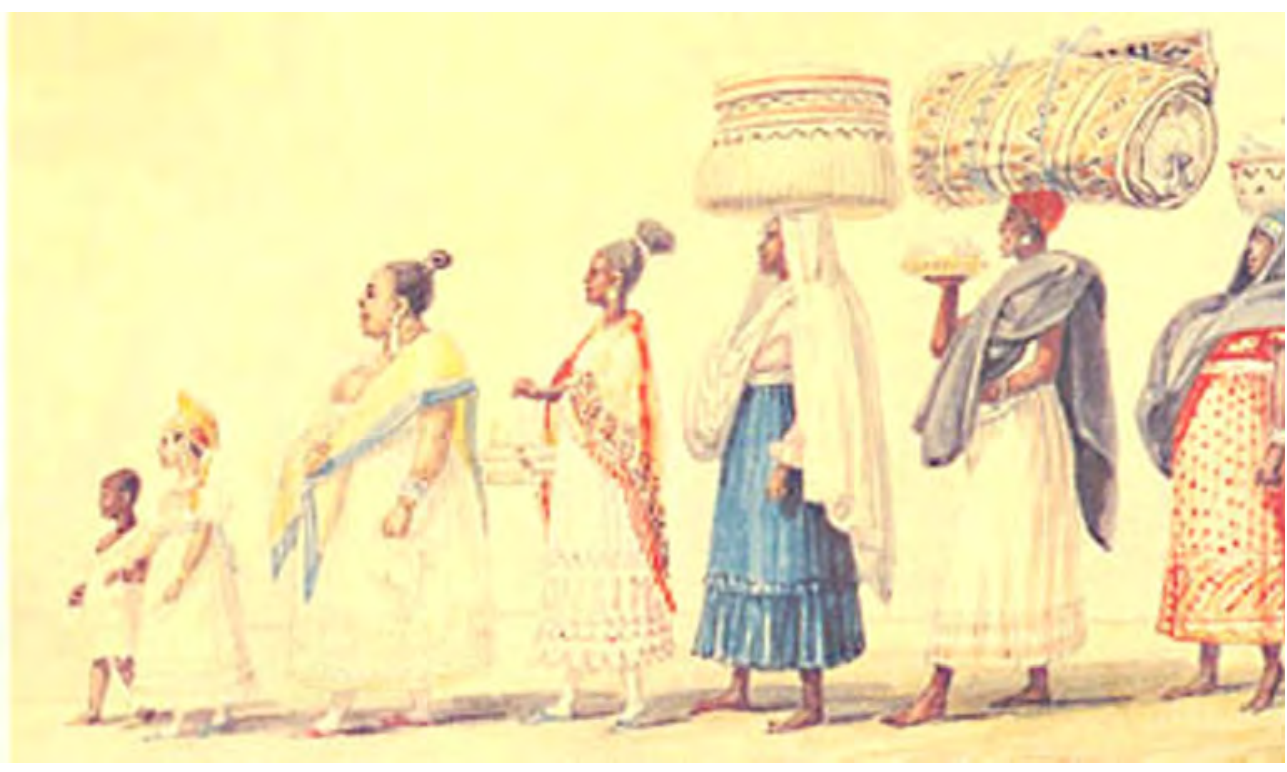

Caderno de Viagem, 1816. JEAN-BAPTISTE DEBRET

Desenho à lápis e aquarela sobre papel. 
Utilizo, em meu caderno "Migração, um recurso de sequencialidade análogo ao que aparece no caderno de Debret, no intento de transmitir a mesma sensação de percurso e trânsito dos personagens. Este foi um livro que produzi em 2014 a partir de um trajeto de trem que me levava até as aulas da Pós-Graduação na ECA. Porém, diferentemente do que ocorre com as personagens de seu caderno que percorrem as páginas enquanto o leitor as observa, em "Migração", é o artista que está em movimento enquanto a paisagem passa através da janela do trem. O formato retangular serve tanto para representar o desenho da janela de um trem como o do próprio trem. Nas páginas, foram utilizadas folhas de papel vegetal, o que pro-porcionou um efeito de profundidade, promovendo um percurso a ser explorado não apenas na topografia das páginas, mas também através delas. A possibilidade de ampliação da paisagem à medida que o livro é aberto também é uma de minhas intenções. Portanto, enquanto produzi as imagens que as páginas receberiam, foi necessário prever a movimentação do desenho através delas. Prever o resultado tanto do folhear das páginas quanto da continuidade dos desenhos. O percurso do trem deve ser percorrido estação a estação, página a página. Sentir a passagem do tempo. A proposta está no próprio tempo de desfrute da obra.

Neste trabalho, a questão do espaço, portanto, vai além da ideia de continuidade e sequência ao virar as páginas do livro. Estende-se para uma ideia de espaço de profundidade proporcionado pela transparência das páginas. A materialidade do papel vegetal afeta a forma como a narrativa se desenvolve. Ao invés de ser uma narrativa puramente linear, há uma noção de um espaço que se amplia e proporciona uma forma de leitura mais livre e ampliada. 


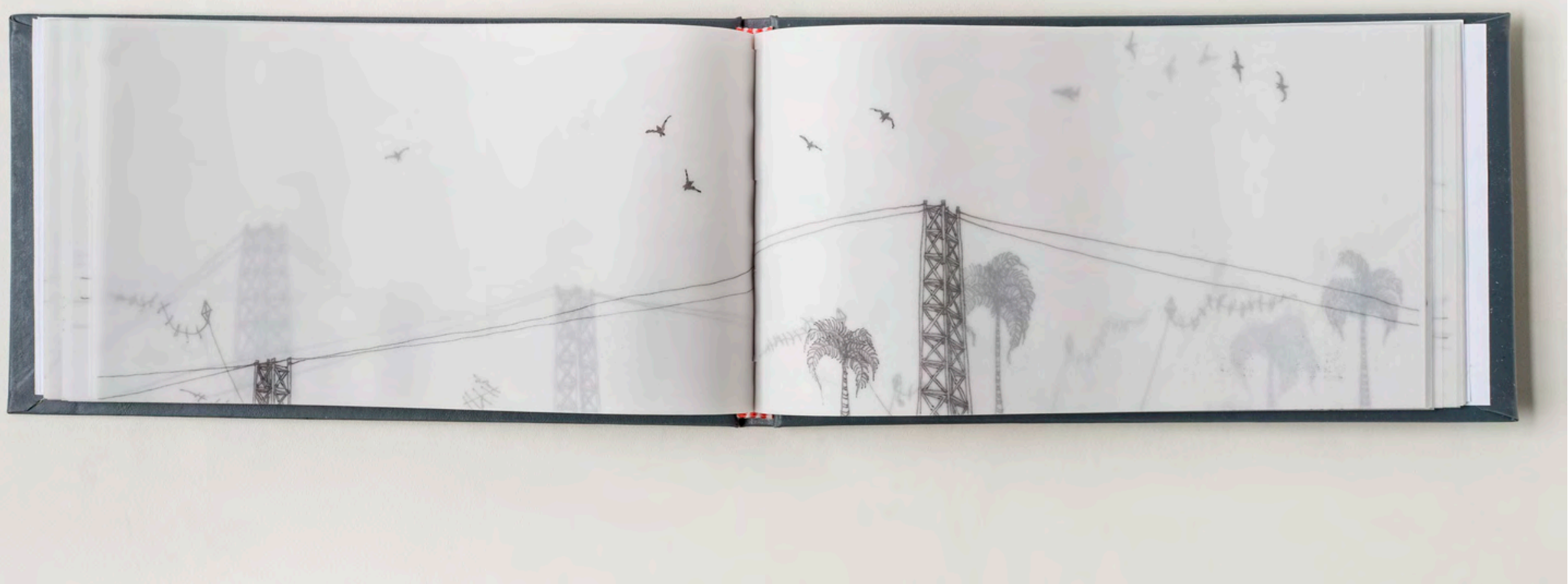

MIGRAÇÃO, 2014

Impressão jato de tinta sobre papel vegetal. Edição 5

7 X $14 \mathrm{~cm}$. 
No texto "El nuevo arte de hacer libros"4, de 1975, Ulises Carrión fala do espaço do livro como uma sequência de momentos, a ser explorada de diversas maneiras e não apenas por meio de textos. Mais tarde Julio Plaza referencia tal texto para tratar do livro artístico e complementa explicando que a linearidade imposta pelo sistema de leitura pode ser substituída pela similaridade e que a montagem do livro pode ser uma solução para ultrapassar os limites formais impostos pela tradição literária ${ }^{5}$. Ambos os autores já citavam a influência do mundo cotidiano na maneira como vemos e lemos o mundo. Se em 1985 Julio Plaza entendia que os cartazes e meios massivos de comunicação produziam em nossa sociedade um novo tipo de linguagem, imagine nos dias atuais, com Instagran, Pop ups e Facebook. Estamos habituados a ler imagens, signos, e a nos comunicar por meio delas. Com certeza "Migração" não poderia ser produzido sem que eu tivesse tal repertório. Sem que tal viagem estivesse tão impregnada em minha vista que pudesse reproduzi-la sem precisar avistá-la. Sem que ela tivesse passado em minha mente como um filme. Sem que eu tivesse visto um filme...

Portanto, além do sistema de leitura, vemos também que tal produção vai de encontro às necessidades do mundo contemporâneo com seus celulares, seus aparelhos portáteis e seus "quero te mostrar onde estive".

4 CARRION, Ulises. “El arte nueva de hacer libros”. In: El arte de los libros de artista. Madri/ Nova York: Turner/ Distributed Art Publishers, 2003. 
O fato de se utilizar um livro prioritariamente visual faz com que a sequencialidade da linguagem verbal, tradicional na literatura, seja substituída por uma percepção da continuidade dos signos visuais. Tal estratégia já teria sido utilizada por Bruno Munari em seu livro "Più e Meno". Nele, Munari utiliza várias pranchas soltas de imagens impressas em acetato, que podem ser sobrepostas de maneiras diferentes e formar novas narrativas e possibilidades de percepção. Interessante perceber que, por se tratarem de pranchas soltas e pelo livro ser direcionado ao público infantil, este trabalho é considerado por muitos um jogo pe dagógico e não um livro. Outra problemática levantada por Julio Plaza era a dificuldade de assimilação destes trabalhos que se encontram em situação limite. Adaptou-se tanto ao modo de produção contemporâneo que perante os modos de produção da arte tradicional e única não é reconhecido. O modo como os livros de artista vêm sendo assimilados é uma discussão que pretendo desenvolver mais adiante.
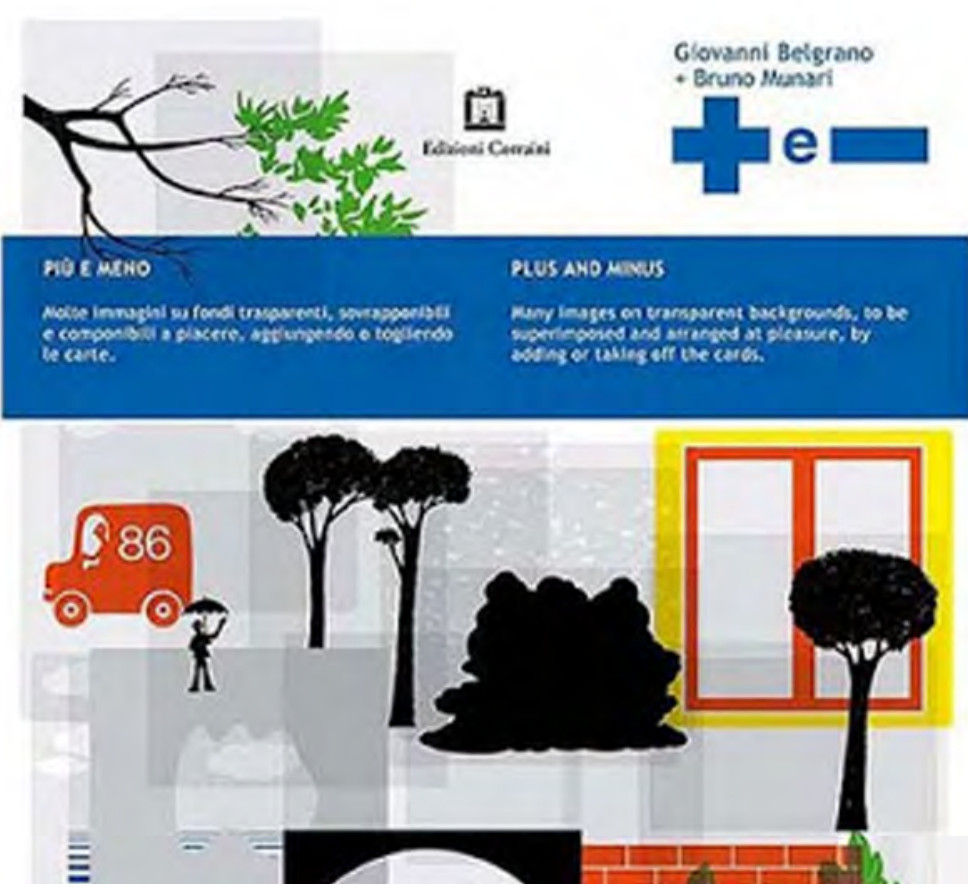

Bruno Munari,

Più e Meno.

Foto: corraini.com 
Outra questão importante em meu trabalho “Migração", é uma equivalência entre a ideia de percurso de um espaço físico no mundo real e a sensação de percorrer o espaço contínuo das páginas do livro. Em ambos, a caminhada serve como ponto de partida para inspiração do conteúdo do livro e se reflete na própria forma como o livro se apresenta para o leitor.

A partir do final dos anos 60, uma série de artistas passou a encontrar nas caminhadas e no encontro com a natureza uma forma de arte que se opunha ao minimalismo e a sofisticada tecnologia da cultura industrial. Os artistas da chamada Land Art propunham que o terreno natural fosse a própria matéria para a obra e não apenas ambiente para abrigá-la. Para o artista Hamish Fulton, a caminhada é parte do conceito artístico de sua obra. Ele elabora o trabalho com as experiências ocorridas durante o tra-jeto e a partir de materiais e sensações des-

te percurso e procura evocar no espectador estados de ânimo poéticos particulares, para que estes a partir de sua obra reelaborem suas próprias cami nhadas. Seu trabalho foi mais difundido por meio dos seus

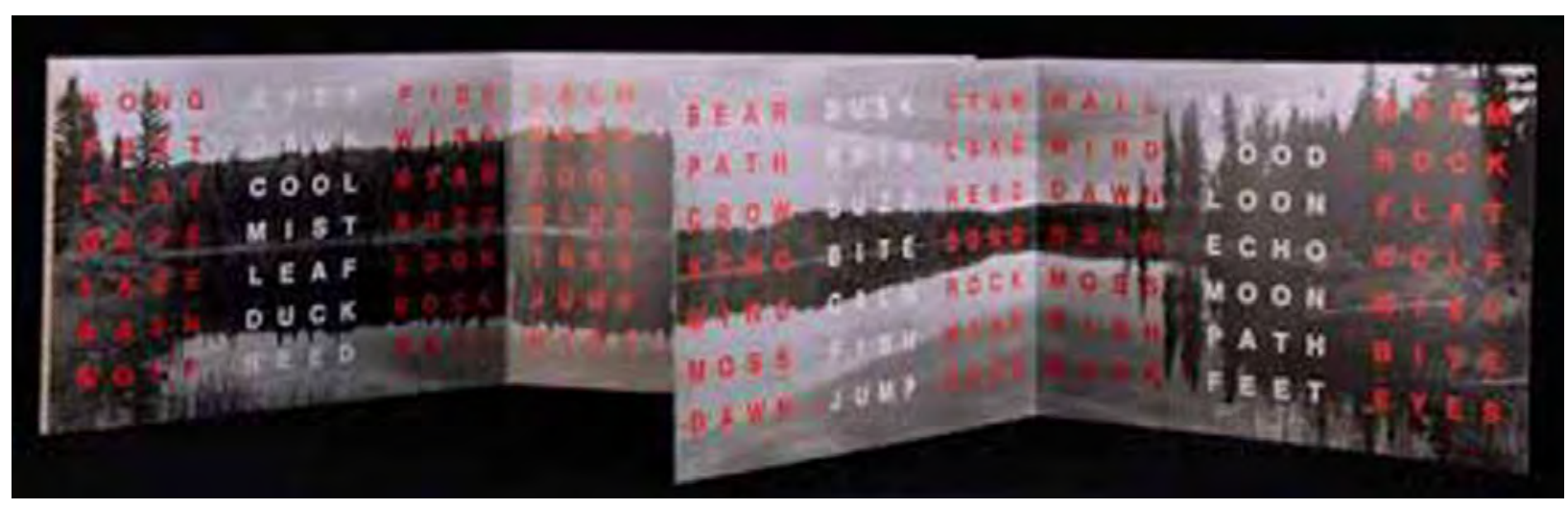




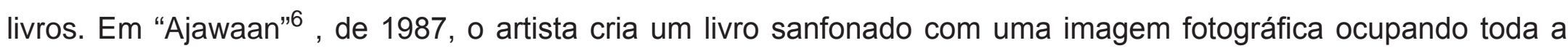
extensão para reproduzir a paisagem de uma de suas caminhadas. Sobrepondo a fotografia desta, uma série de palavras que aludem a objetos e sensações vividas neste percurso. O artista também faz uso da sequencialidade e multiplicidade para produzir seu livro. O formato do livro, ao se estender, proporciona um prolongamento de percurso junto ao próprio objeto livro, o que potencializa as caracte-rísticas de um trabalho que pretende ser um comentário sobre a paisagem. $\mathrm{O}$ fato de o livro se dobrar e possibilitar pequenas e grandes dimensões em um mesmo trabalho também contribui conceitualmente para o trabalho e nos remete ao livro de bolso.

Semelhante ao formato utilizado por Hamish Fulton em "Ajawaan", ao construir meu livro "Ponte Orca", de 2002 queria buscar uma forma de transmitir relações estabelecidas durante o seu processo de execução. Este é um dos primeiros livros que produzi. Não era um livro nas formas e regras do Volume tradicional, mas um li vro em sintonia com as heranças construtivas brasileiras pro-duzido com o objetivo de ocupar o espaço, como no sonho de Mallarmé de um livro aberto ${ }^{7}$. O "Livro do Tempo" de Lygia Pape é um bom exemplo de livro aberto. Suas páginas soltas dialogando diretamente com o espaço nos possibilitam uma visão geral de sua totalidade e, ao mesmo tempo, percorrer as páginas vislumbrando cada detalhe. Ponte Orca não possui capa. Suas páginas não ficam soltas, mas estão unidas por fita adesiva, produzindo uma longa sanfona por onde o desenho caminha de uma página a outra podendo ser avistado de uma só vez e não possui capa. Foi pensado para ser experienciado aberto e sob uma base móvel. Em verdade, apenas depois de pronto entendi tratar-se de um livro. O construí com bilhetes de trem que fui colecionando durante o ano de 2001. Os bilhetes são de um trajeto de trem que liga a cidade universitária à minha antiga residência. Depois de um ano de coleta, uni os bilhetes em ordem cronológica com fita adesiva formando uma grande sanfona de papel. Na parte traseira dos bilhetes, desenhei a vista que tinha da janela durante esse trajeto. Eram muitas torres de alta tensão, pipas, fios e antenas de tv.

7 SILVEIRA, Paulo. A Página Violada: da ternura a injúria na construção do livro de artista. Porto Alegre: UFRGS, 2001. 

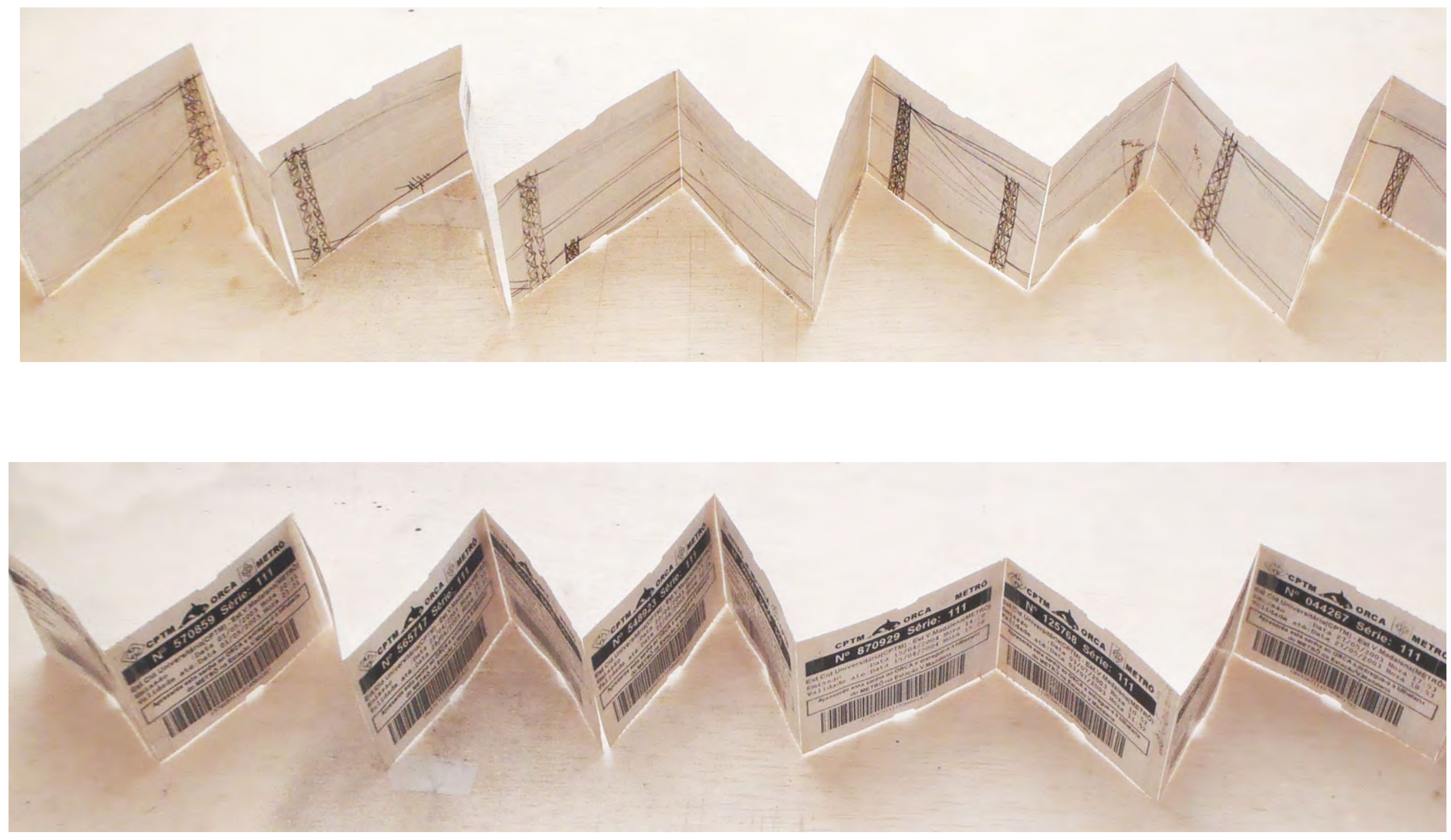

"PONTE ORCA", 2002.

Nanquim sobre bilhetes de trem, fita adesiva e base de madeira. 100 X 100 X $5 \mathrm{~cm}$ 
Além da sequencialidade na coleta dos bilhetes e no desenho que continua de uma folha para a outra, um outro elemento surge neste trabalho e será recorrente em outras obras: é a expansão do trabalho para além do livro. Esta característica será explorada de maneiras diversas nos trabalhos seguintes. Explorando o percurso existente no espaço do livro e buscando criar um percurso real para o observador ao fruir a obra. Como uma pessoa com um mapa caminhando por uma cidade. Existe o desenho do mapa e o desenho da própria cidade e a pessoa tentando se localizar nos dois espaços.

Quando apresentei "Ponte Orca” pela primeira vez, construí uma base retangular comprida, como um vagão de trem com uma cúpula de acrílico. A base possuía rodinhas, possibilitando que ela fosse deslocada como um vagão. Em um dos corredores da galeria instalei uma catraca de ônibus para que o espectador, ao circular na sala, tivesse que utilizar a catraca. Assim, um som de catraca virando era constantemente ouvido durante a visita da exposição. A circulação no espaço expositivo e na cidade eram o meu interesse naquele momento e percebo que, a partir deste trabalho, o percurso começou a ser matéria plástica para mim. E é interessante pensar na relação de percurso e portabilidade do trabalho estão sutilmente conectados. Tanto o percurso realizado por meio das páginas, quanto a memória do percurso. A narrativa é construída por meio do suporte e da mensagem ou, em muitos casos, a mensagem está no próprio suporte. 


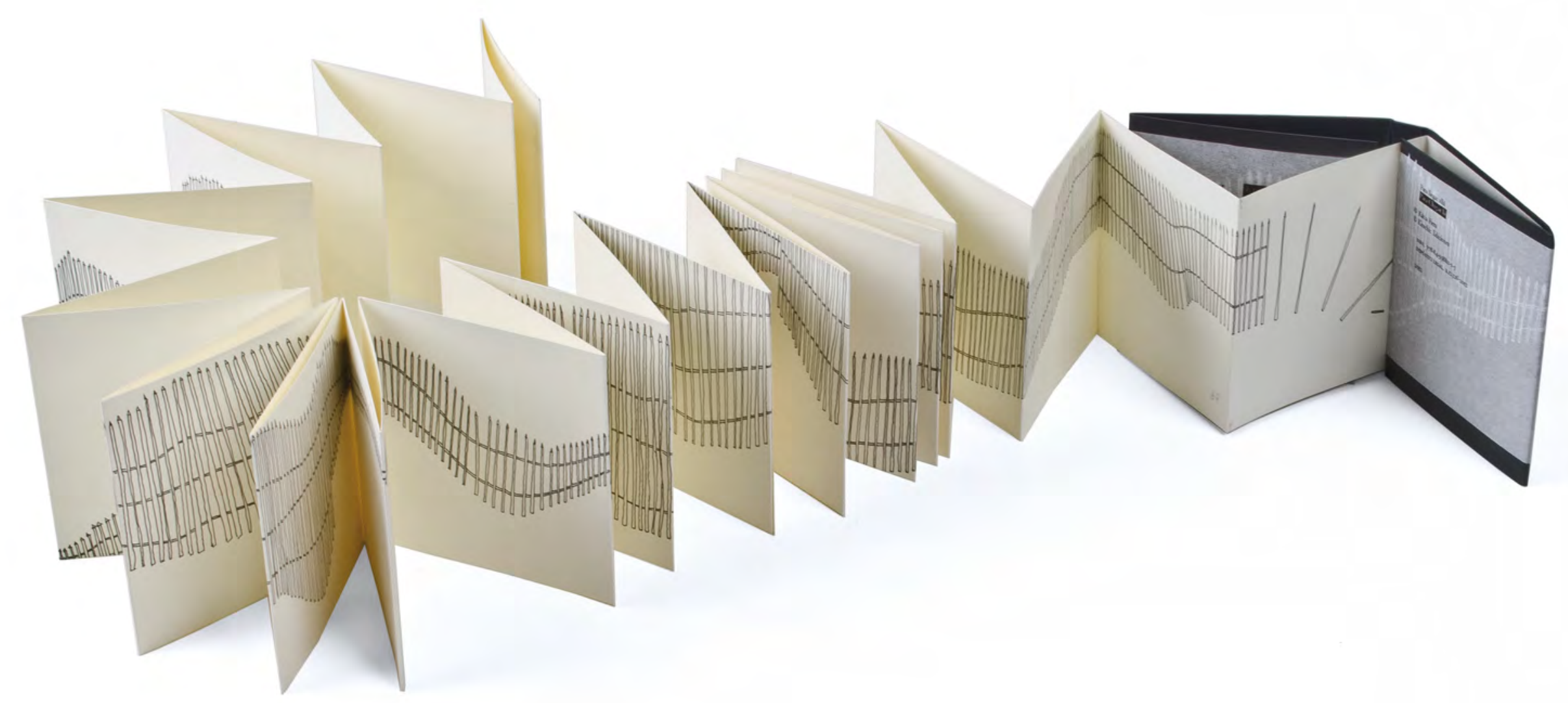

Para Chegar Lá, 2012

Impressão offset e serigrafia sobre papel.

10 X $10 \times 333 \mathrm{~cm}$. 
Percebo que, à medida que produzo um trabalho, o fazer me leva a reflexões que, por sua vez, me impulsionam a produzir outro trabalho. As reflexões surgidas a partir de "Ponte Orca" me levaram a compreender que a edição de alguns trabalhos era funda-mental. Em um primeiro momento mais por conta da montagem, pois naquele momento, como $o$ trabalho não possuía grande cir-culação, parecia não valer a pena investir tempo e dinheiro em uma grande tiragem.

O trabalho seguinte surgiu da necessidade de produzir algo que fosse uma representação da passagem do tempo, e que fosse pequeno o suficiente para caber no bolso em caso de necessidade. "Para Chegar Lá" foi o primeiro livro que editei. Houve, porém, um intervalo de 10 anos entre sua feitura e sua edição. O original foi produzido durante o processo de desativação do Carandiru, em 2002. Naquele período, ao longo de dois meses, o espaço do presídio foi aberto à visitação do público que poderia ter uma noção de como os presos viviam ali dentro. Trabalhei ali em um projeto educativo e, enquanto convivi no local, percebi que além da arquitetura gigantesca e opressora, havia uma falta de paisagem. Embora os presos não estivessem mais lá, ainda era pos-sível sentir o eco dessa ausência. Pelas pinturas de paisagens produzidas logo abaixo das janelas, que davam para os muros. Pelos tecidos pendurados na janelas, como bandeiras de rendição.

Decidi desenvolver ali um trabalho que também veio a ser um livro. Passei a levar um pequeno caderno de bolso para o local e me propus a produzir duas páginas por dia até criar uma cerca interminável. A cada dia buscava uma nova possibilidade de trajeto reiniciando o trabalho a partir de onde havia terminado no dia anterior. Aqui, mais uma vez, os elementos de continuidade e multi-plicidade surgem durante o processo. Desta vez, porém, a permanência também se faz presente. A cerca marcava a contagem do tempo, como os riscos na parede feitos pelos presos para contar os dias. De alguma maneira, por um curto período eu também estive presa lá. Marcava a minha permanência no local, posto que ao final dos dois meses a cerca cai e não intervenho mais no trabalho. Marca a 
permanência obrigatória de quem ocupou o local, mesmo que como um resíduo de sensações transmitidas, e a tentativa de perpetuar tais sensações de um local que logo mais não estaria disponível. Ao final do período de visitação, o presídio foi implodido.

Quando o desenho foi terminado logo percebi que precisaria ser editado. O original possuía páginas coladas e com o excesso de manipulação logo passaram a se desprender. Ao mesmo tempo, era um trabalho que só poderia ser acessado ao ser manipulado. A primeira edição caseira que produzi foi de apenas dez unidades e não ficou com boa qualidade. Era muito oneroso e trabalhoso o processo devido ao grande número de páginas, portanto deixei o projeto de lado.

A oportunidade de sua edição surgiria dez anos depois, quando uma editora de Barcelona se interessou. No momento da edição, já em 2012, o livro ganhou um novo formato, o de sanfona. Desta maneira, seria possível de uma só vez ter a visão da paisagem- cerca em sua plenitude, o que não poderia acontecer no desenho frente e verso das folhas. Desta maneira também seria possível ter a percepção do tempo, ou da distância percorrida pela dimensão do trabalho e, novamente, a dialética do pequeno e do grande, do partir e do ficar, da transitoriedade e da permanência estão presentes. 


\section{Topografia e Materialidade na Construção}

Ao falar de topografia do livro, me refiro tanto à superfície de suas páginas, quanto à representação da superfície de um terreno. O espaço da página pode ser branco e imaculado ou pode apresentar acidentes, recortes e depressões. Essas cicatrizes impressas nas páginas são mais um elemento, além da estampa ou dos formatos, que o artista pode utilizar na construção da narrativa. Essas impressões falam por si só. Cada mancha, cada dobra e cada rasgo carrega uma memória e o artista pode utilizá-los como signo de uma memória pessoal, mas que também podem se converter em memórias de outras pessoas que acessam seus próprios repertórios por meio da obra do artista. Uma mancha de café ou de cerveja, pode nos remeter ao lar ou ao bar, dependendo do contexto.

Em "Markischer Sand V, de 1977, Anselm Kiefer utiliza areia sobrepondo as fotografias do livro para nos transmitir a sensação de passagem do tempo. A cada página a camada de areia se torna mais espessa, dificultando a visão da imagem fotográfica até o ponto de soterrá-la por completo. Como uma duna cobrindo a paisagem até soterrar uma cidade, apa-gando o passado. O tratamento das páginas de Kiefer nos conduz à narrativa sem necessidade de uso de palavras.

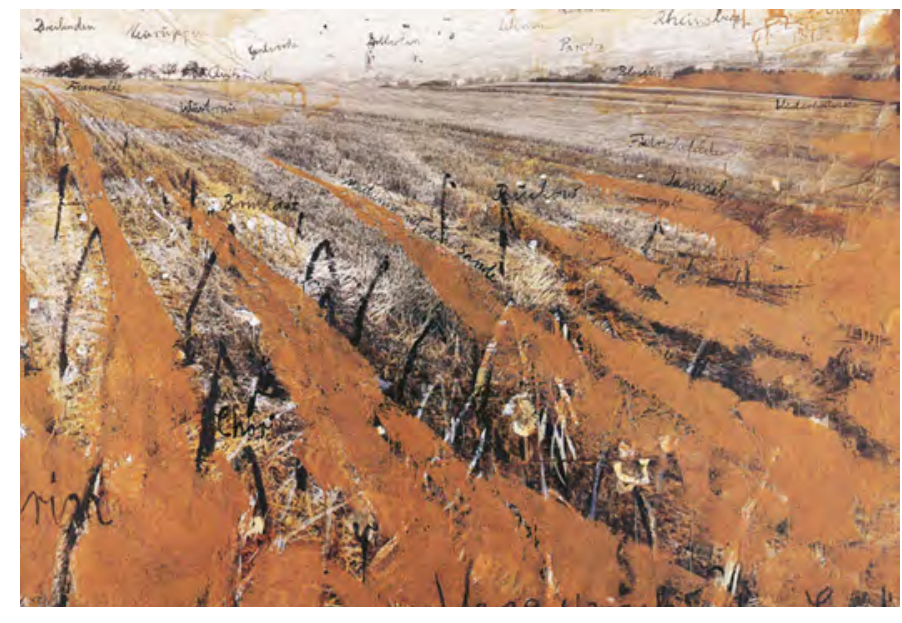

Anselm Kiefer Markischer Sand V, 1977 Foto: saatchigallery.com 


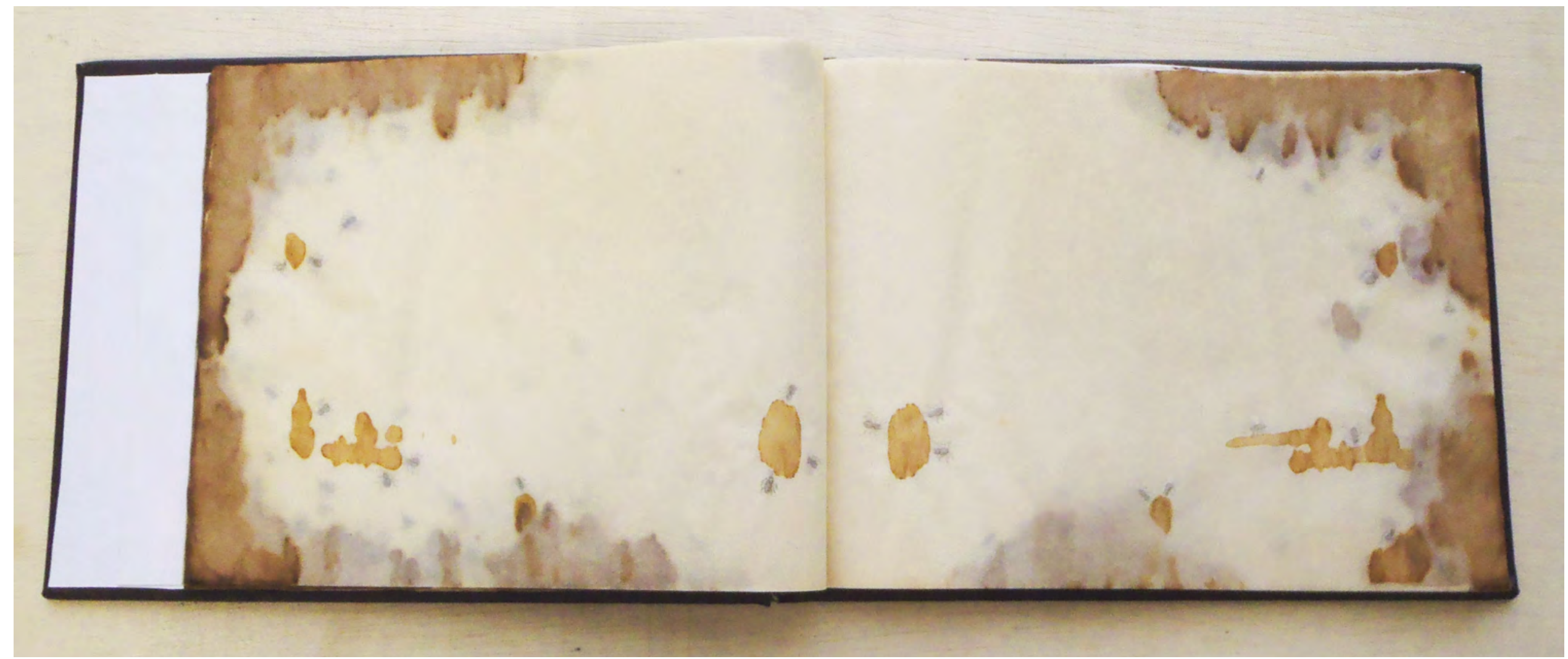

CAFÉ COM FORMIGA E MELANCOLIA”, 2005.

Grafite sobre papel manteiga e café.

$15 \times 22 \mathrm{~cm}$. 
Em meu trabalho "Café com Formiga e Melancolia", de 2005, produzi um livro a partir de uma mancha de café em um bloco de papel manteiga. As manchas formaram desenhos parecidos com paisagens de montanhas e precipícios. Percorrendo os desenhos que a mancha de café formava, reproduzi pequenas formigas que caminham até o final do livro. Pretendia, com isso, levar o observador ao mesmo estado que me levou a realiza-lo. Uma memória de vida caseira. De ver as formigas atravessarem o quintal. Este livro foi criado para a minha primeira exposição individual, em 2005. Em frente ao livro, exposto em uma base, se encontravam varais como os de roupas, onde desenhos sobre camadas de papel vegetal estavam pendurados. Acima do varal, duas Pipas sobrevoavam a instalação. O quintal de minha infância se materializara ali, com o livro como portal se abrindo para memórias. Já nesta exposição, várias questões do meu trabalho já estavam presentes: a narratividade através do deslocamento das formigas ao longo do livro, a materialidade das páginas enrugadas com o café, e a relação com o espaço tridimensional que resultava da interação do livro com as outras obras da exposição. Pensar as maneiras de expor o objeto livro me parece algo cru-cial para quem pretende produzir um livro-obra. Não fazê-lo é como produzir qualquer trabalho de arte e não prever a maneira como será exposto. Seria eliminar um elemento de construção muito rico para ser desperdiçado. Tratarei mais a fundo o tema da construção do livro no capítulo 2. 
Em 1978/79 Arthur Barrio apresentou seu "Livro de Carne" pela primeira vez. O estranhamento em percorrer e manipular páginas de carne é suficiente para o observador perceber toda a violência e efemeridade da obra. A materialidade não representa a carne, ela é a própria. Ao utilizar um material específico para construir as páginas do livro, o artista agrega um elemento tão significativo que torna a obra completa. A escolha do terreno que represente a paisagem perfeita para a obra que o artista pretende construir.

No livro "Fronteiras", de 2008, o tecido representado nas roupas que sacodem no varal é o mesmo utilizado como página. Temos a sensação de atravessar os varais a medida que percorremos suas páginas. O livro trata das fronteiras entre os países como quintais de casas, por onde se pode passar de uma casa para outra através de suas cercas, como crianças brincando de esconde-esconde.

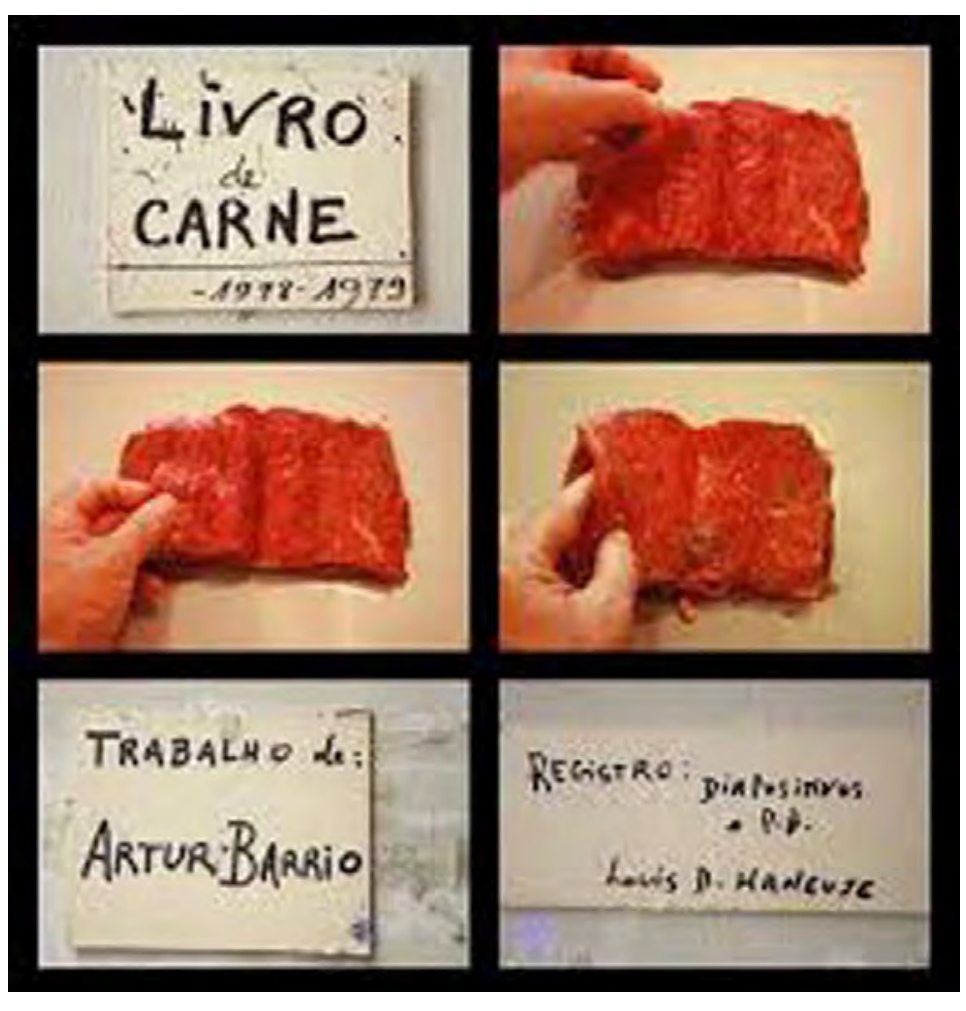

Livro de Carne, 1979 ARTHUR BARRIO

Foto: literatortura.com 


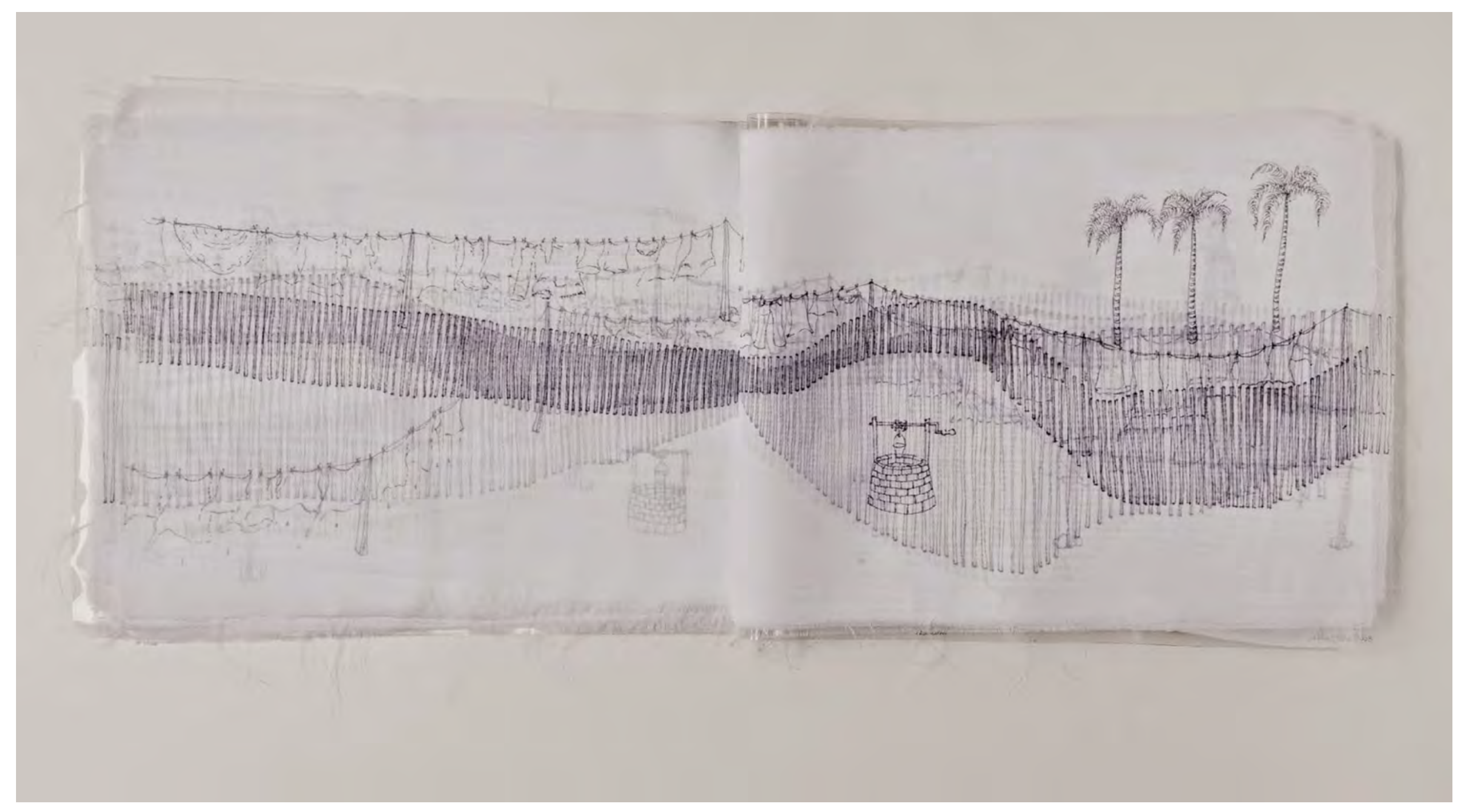

FRONTEIRAS, 2008

Caneta de tecido sobre voal. $40 \times 105 \mathrm{~cm}$. 
Antes de ter oportunidade de mostrar o livro "Fronteiras" em uma exposição, acabei expondo um trabalho que surgiu em decor-rência dele. Após a experiência com as folhas de papel vegetal expostas como roupas em varais surgiu a vontade de reapresentar o trabalho só que dessa vez como uma grande instalação e substituindo as páginas de papel vegetal por camadas de tecidos. O espaço percorrido mentalmente pelo leitor agora estaria desdobrado em um espaço a ser percorrido fisicamente por quem adentrasse a Galeria do SESC Paulista. Em "Quintais: Pipas e Varais" era possível atravessar os varais e esbarrar nos tecidos. Ter a paisagem representada nos tecidos misturada a paisagem formada pelos varais e a das pessoas passando pela calçada, vistas através das paredes de vidro da galeria. O visitante poderia escolher o percurso que quisesse por entre os varais e, assim, a narrativa do trabalho ficaria não linear.

Vilém Flusser nos fala do pensamento-em-linha e do pensamento-em-superfície. A diferença entre ler linhas escritas e ler uma pin-tura. Segundo ele: "Ao lermos as linhas, seguimos uma estrutura que nos é imposta; quando lemos as pinturas movemos-nos decerto livremente dentro da estrutura que nos foi proposta... Podemos abarcar a totalidade da pintura num lance de olhar e então analisá-la de acordo com os caminhos mencionados... O que significa que a diferença entre ler linhas escritas e ler uma pintura é a seguinte: precisamos seguir o texto se quisermos captar sua mensagem, enquanto na pintura podemos apreender a mensagem primeiro e depois tentar decompô-la"8 .

8 FLUSSER, Vilém. O mundo codificado: por uma filosofia do design e da comunicação. São Paulo: Cosac Naify, 2007. 


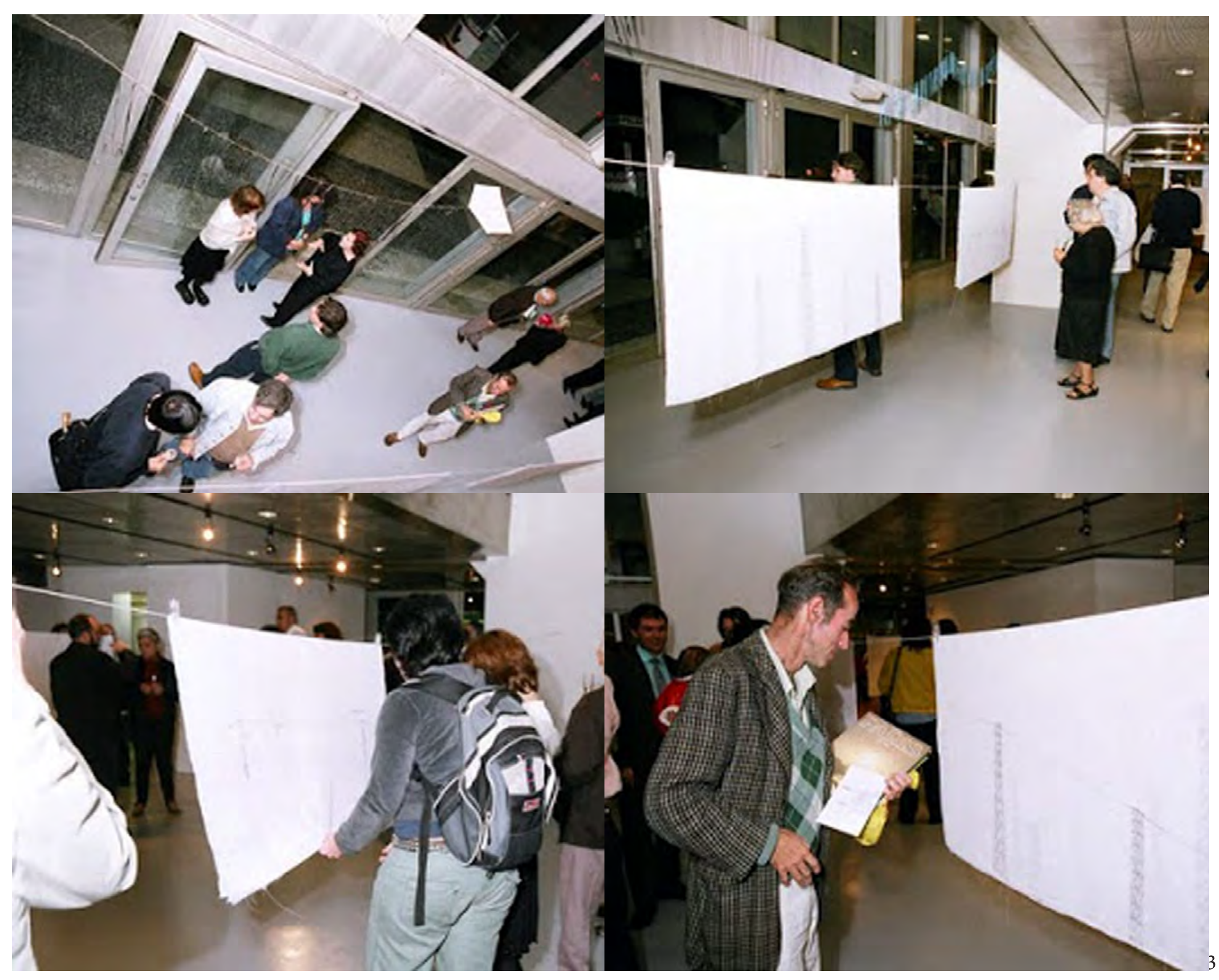

Quintais: Pipas e Varais, 2005

Desenho sobre tecido, cordas de varal, prendedores de acrílico e Pipas. 
Acredito que esse pensamento-em-superfície se aplique aos livros de artista que citei até aqui e os diferencie dos livros comuns. O fato de, ao avistarmos suas páginas, assim como a topografia de uma paisagem, e conseguirmos ter uma visão geral do seu con-teúdo sem necessariamente percorrer toda a sua extensão e a possibilidade de construir novas narrativas a partir de uma leitura pessoal de quem se aventura a cruzar suas páginas no ritmo e direção que quiser. Um outro livro que produzi neste período foi "O MELANCÓLICO VENTANDO COM XINGU". Este livro também foi produzido a partir de uma mancha, só que, dessa vez, de cer-veja preta. Nesse período, frequentei a disciplina "Sobre a Linha" na pós-graduação da ECA. Ali, certa vez, o Prof. Dr. Luiz Armando Bagolin palestrou a respeito da figura do melancólico. Segundo ele, na fisiologia de Hipócrates, a bile negra estava ligada aos tempe-ramentos sanguíneo, fleumático e colérico, e seu desequilíbrio geralmente era causado por "substâncias negras nefastas" que obscureciam a razão, o que fazia com que o indivíduo fosse tomado por uma espécie de loucura ou frenesi. Por isto, a melancolia na Grécia, estava intrinsecamente relacionada à excitação do pensamento e à capacidade de raciocinar: "Assim, pois, maravilhoso amigo, nada falta a um homem para ser tirânico, quando a natureza, suas práticas ou as duas juntas fizeram-no bêbado, apaixonado e louco (melancholikos)"9. Segundo a crença na Grécia antiga, a uva, por sua constituição, conteria vento; e ao beber o vinho a pessoa ventaria e este seria o estado melancólico. Lembro-me de ter pensado na ocasião: "quem venta com vinho deve ventar com cerveja também", e foi a partir dessa palestra que o trabalho surgiu. O desenho foi produzido a lápis, material que pode ser apagado. Algo que me lembrasse dessa situação como passageira. Como uma tempestade que vai passar. Escolhi a cerveja "Xingu" por ser um nome de local brasileiro e por ela ter uma coloração bem escura, que marcaria bem as páginas e pela relação com o texto de Platão, "Substâncias negras e nefastas". Pois é inte-ressante como o mundo e, principalmente o Europeu, associam os países de clima tropical com a felicidade. Como um local onde, supostamente, não há espaço para a introspecção e a melancolia. Pensei também na problemática do alcoolismo nas populações indígenas, já que estamos falando de "Xingu". Um problema resultante da aproximação do indígena com o homem branco. Suas páginas contêm ondulações resultam da mancha de cerveja, o que ressalta ainda mais sua materialidade. É um livro que nasceu para ser único 


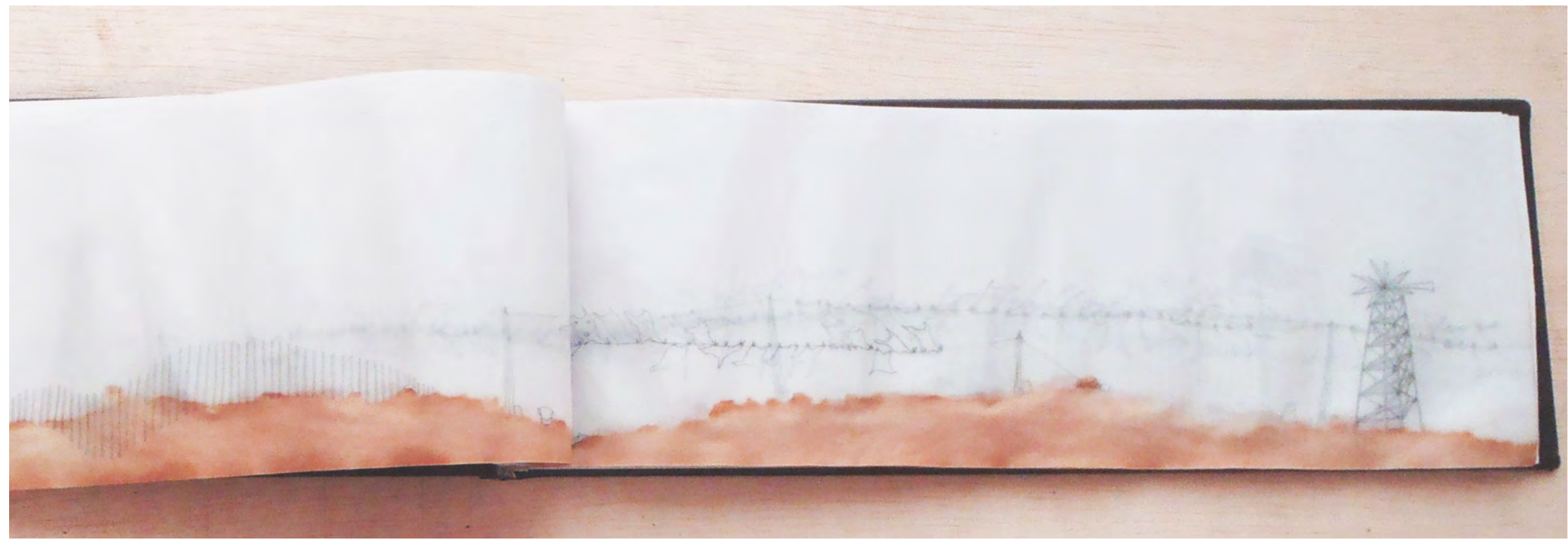

O MELANCOLICO VENTANDO COM XINGU, 2008

Desenho a lápis sobre papel vegetal e mancha de cerveja.

$10 \times 60 \mathrm{~cm}$. 
Em 2014, fui convidada para publicar algo pelo coletivo Dulcineia Catadora. O coletivo é formado por catadores de papelão e a artista plástica Lúcia Rosa. As capas são criadas com o papelão recolhido pelas catadoras. O miolo é impresso em papel reciclável e o título, cedido pelos autores. A partir de 2009, elas começaram a editar alguns livros de artista. Meu projeto foi rea-lizar o livro todo em papelão. O material me trouxe à memória pessoas de uma comunidade próxima da cidade universitária que vive em casas de papelão. Queria produzir algo que tivesse a ver com o cotidiano das catadoras e que fosse uma criação coletiva, para que elas fizessem parte da construção da obra e não somente entrassem com a manufatura no processo. Dos 12 anos em que venho desenvolvendo meu trabalho, em pelo menos dez exerci o papel de educadora concomitante ao de artista. Percebi que este seria um bom momento para unir as duas profissões e apresentei a proposta de ensinar às catadoras o processo de impressão em serigrafia e implantá-lo no coletivo. Assim, poderíamos imprimir as imagens no papelão e ter o mínimo de custo na produção do livro. A serigrafia possibilitaria que todo o livro fosse produzido com o papelão recolhido pelas catadoras.

Numa das minhas atividades de educadora, ao dar a introdução à técnica de impressão, propus uma atividade que uniria a apren-dizagem da serigrafia juntamente com a proposta de uma criação coletiva. O livro teria o formato de uma casa, com páginas em lugar de cômodos. Cada uma das participantes deveria desenhar tudo o que tinha de importante e que conseguisse colocar em um cômodo só. Um exercício de síntese facilmente executado por pessoas que conhecem bem o que é viver com muito pouco. O que deveria ser feito era desenhar no ambiente tudo que fosse de mais importante, de modo que, se precisassem deixar sua casa às pressas não pudesse ser deixado para traz. Daí o título "Só o que se pode levar". Coisa muito comum em comunidades carentes são os incêndios e o ter de carregar seus pertences as pressas. Muitos acabam perdendo tudo. 
Cada membro do coletivo desenhou seu ambiente que, posteriormente foi transformado em uma matriz serigráfica. Criamos um livro em que cada cômodo é uma casa. Imprimimos em papelão e a pintura que as participantes do coletivo fazem tradi-cionalmente na capa dos livros veio para dentro do livro, completando seu conteúdo. Apesar de o livro ter uma edição de 60 peças, a pintura acabou fazendo com que cada livro se tornasse único.

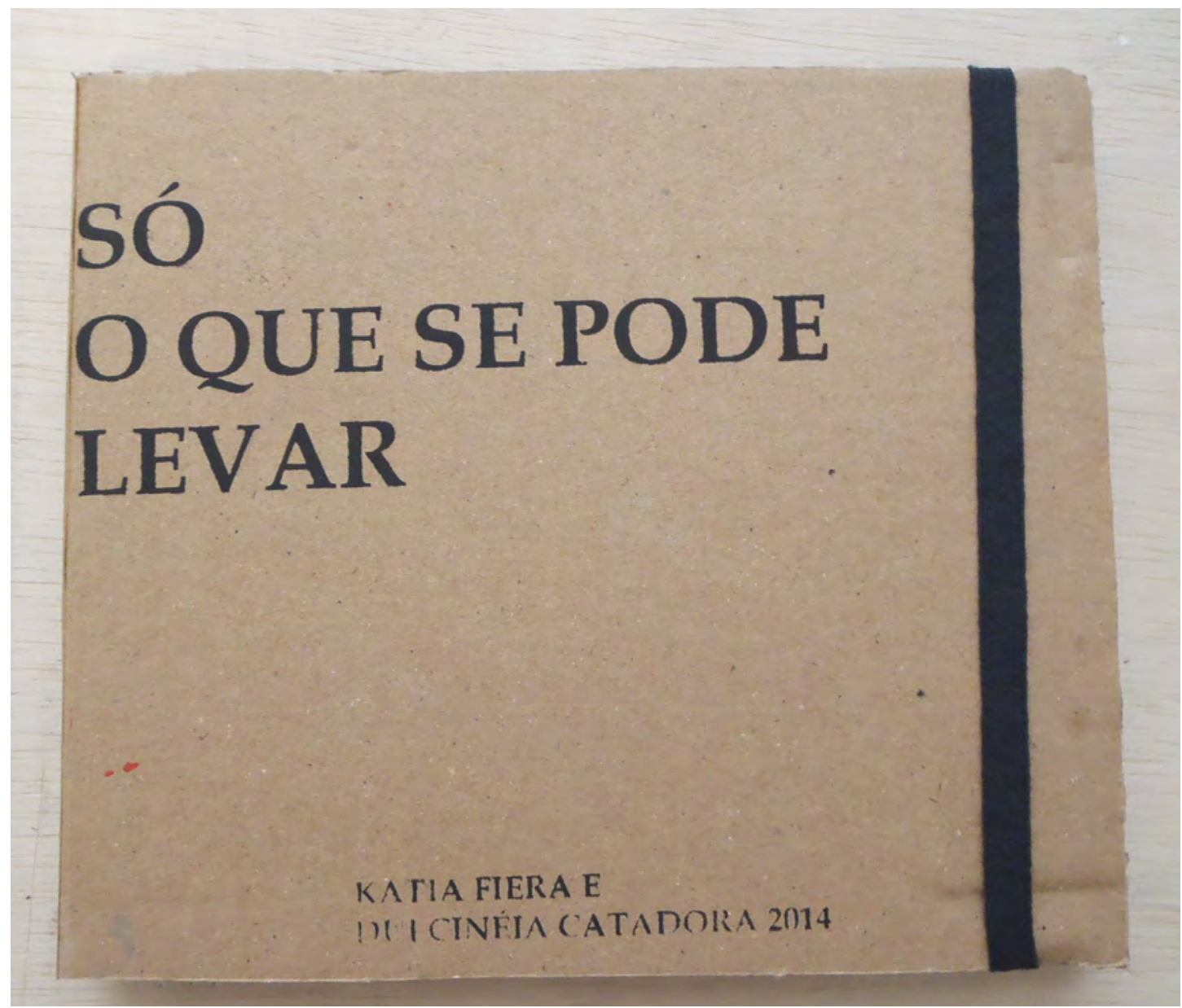




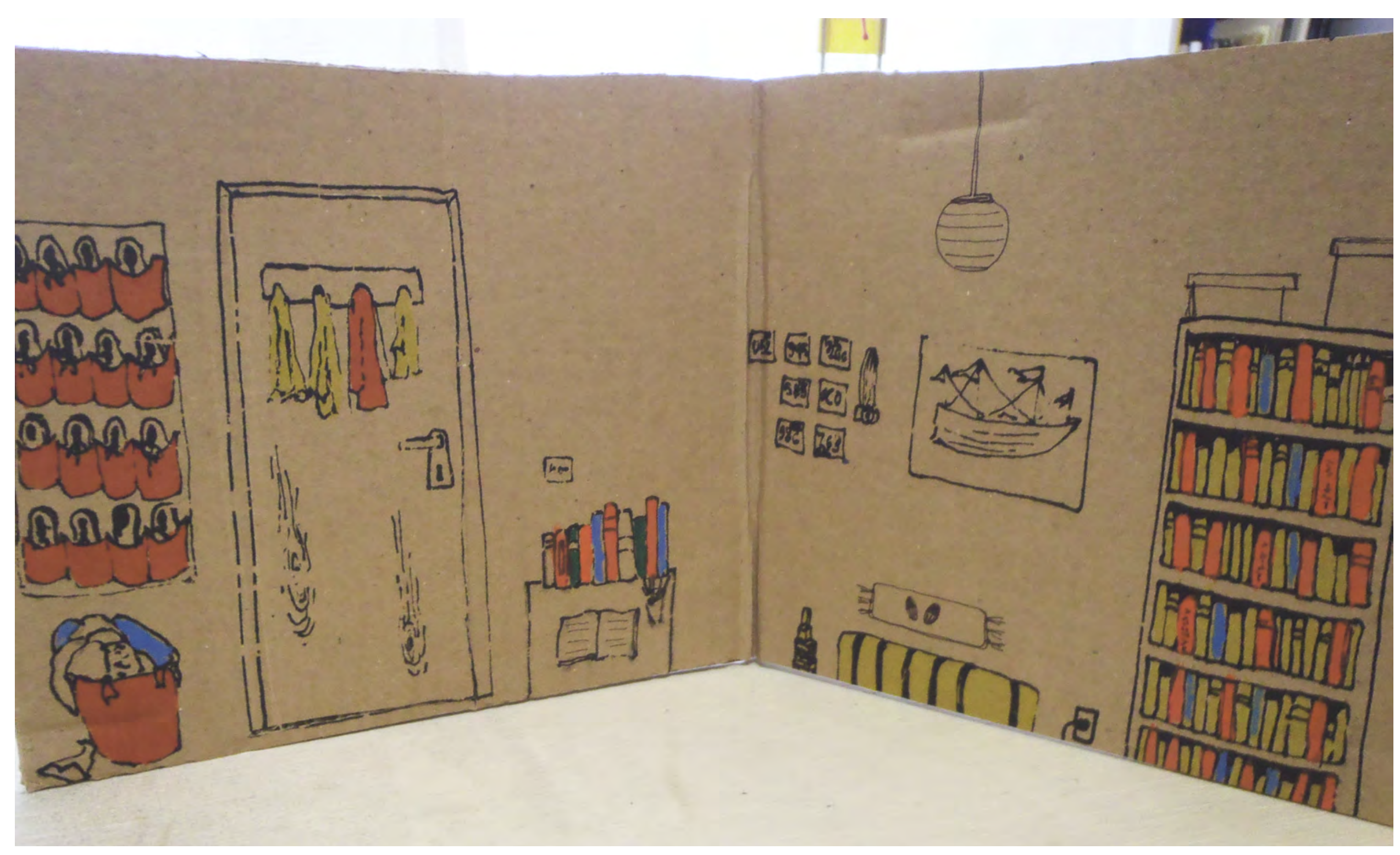

SÓ O QUE SE PODE LEVAR, 2015

Serigrafia e pintura sobre papelão. 
Em seu texto "O livro como forma de arte"10 , Julio Plaza nos apresenta a materialidade do livro como um exemplo de montagem sintática, onde a mensagem estética é fortemente autorreferente dando um caráter de ambiguidade ao trabalho. Neste caso, o suporte é forma-significante, e existe uma forte concessão entre a informação e o suporte. Isso nos traz mais um dado, que seria a relação entre a construção, ou montagem, e a materialidade do trabalho. Ambos funcionam como aspectos indissociáveis. É no ato da construção que o artista decide o material e o formato do livro e tal decisão é, muitas vezes, o que move a narrativa do tra-balho. Como no caso de "Só o que se pode levar" em que o assunto das moradias precárias está no próprio material de construção do livro, o papelão. O livro também apresenta uma característica na construção que passou a ser uma busca constante em meus trabalhos, a construção do livro explorando a possibilidade de edificação do objeto sem que ele perca a característica de poder ser folheado também. Acrescenta ao trabalho múltiplas possibilidades de apresentação e manipulação. Prever que o livro de artista, como objeto artístico pode e deve ser exposto, mesmo que seja em uma banca de Feira e pensar em formatos e maneiras de explorar esta relação do objeto com o espaço. 


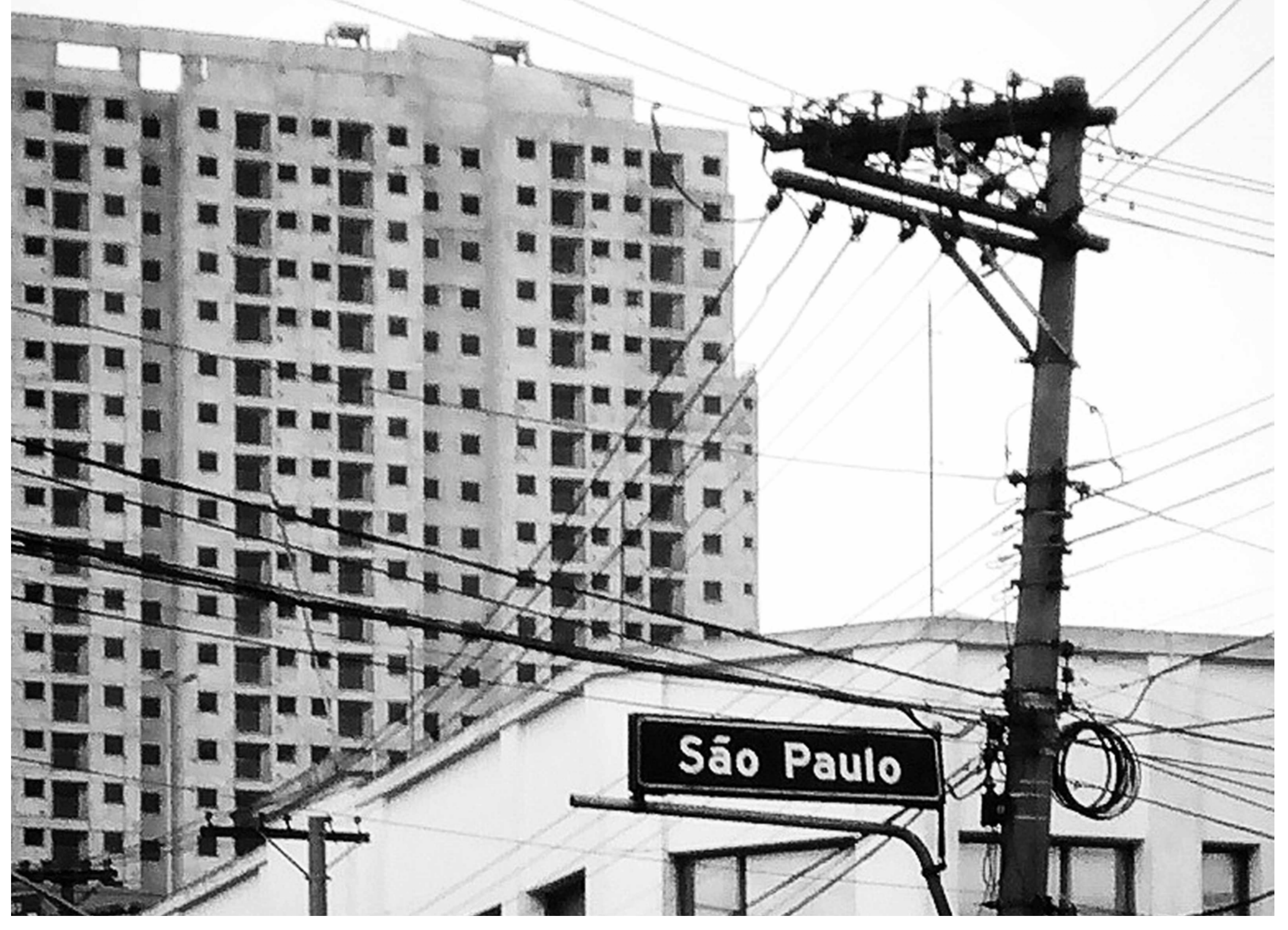




\section{CAPÍTULO 2}

Arquitetando páginas, imaginando espaços ou grandes pequenas coisas

Sempre que inicio a construção de um trabalho (ou seria melhor dizer a construção do espaço por meio do trabalho) sinto que é impossível desvincular sua feitura do tempo e do trajeto de percorrer tal espaço. Heidegger nos fala de medir o espaço através do tempo. Esta seria uma maneira de perceber o espaço. Sem nos dar conta disto, medimos o espaço de diferentes maneiras ao longo da vida e em determinadas circunstâncias. "Medimos nossa altura no batente da porta à medida que crescemos; a circunferência de uma árvore tentando circundá-la com nossos braços; a distância até a nossa casa tentando correr até ela antes que alguém perceba que já fomos; o tempo que temos até dormir em termos de quanto mais de uma história ainda pode ser contada."11 Muitas vezes a maneira de percorrer tal espaço é o que faz gerar seu suporte, tanto no caso da instalação como no do livro. As relações físicas que estabelecemos ao percorrer esse espaço são parte do trabalho. Se atravessamos uma casa ou se cruzamos uma fronteira até um outro país ou se subimos uma escada ou saltamos a cerca de um quintal. Cada um destes trajetos tem um tempo implícito e um tipo de sensação física.

Em 2008 produzi "Andando na linha", onde, além da materialidade do livro, busquei explorar as relações físicas que poderiam ser estabelecidas por meio de sua manipulação e escala. As páginas foram construídas com desenho sobre plástico e sua dimensão bem alongada, de maneira que quando aberto essa dimensão se duplicaria fazendo com que o leitor, ao manipulá-lo, tivesse de caminhar para virar suas páginas, reproduzindo no leitor o vai e volta realizado por um trem em sua linha. O reflexo da transparência do plástico, tal qual o vidro de uma janela de trem, e o tempo de percorrer a linha do horizonte na própria linha do desenho também eram o meu interesse. 


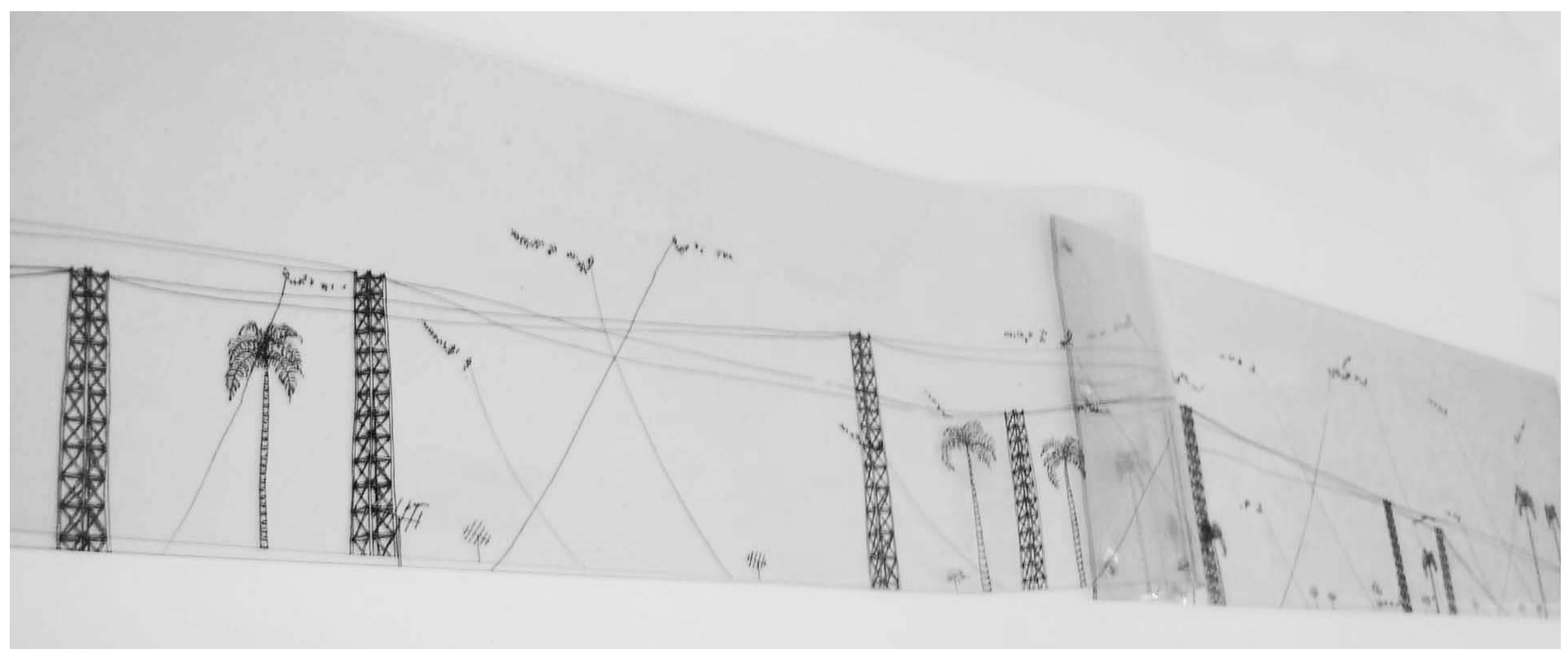

Andando na Linha, 2008.

Caneta marcador permanente sobre plástico. $20 \times 128 \mathrm{~cm}$. 


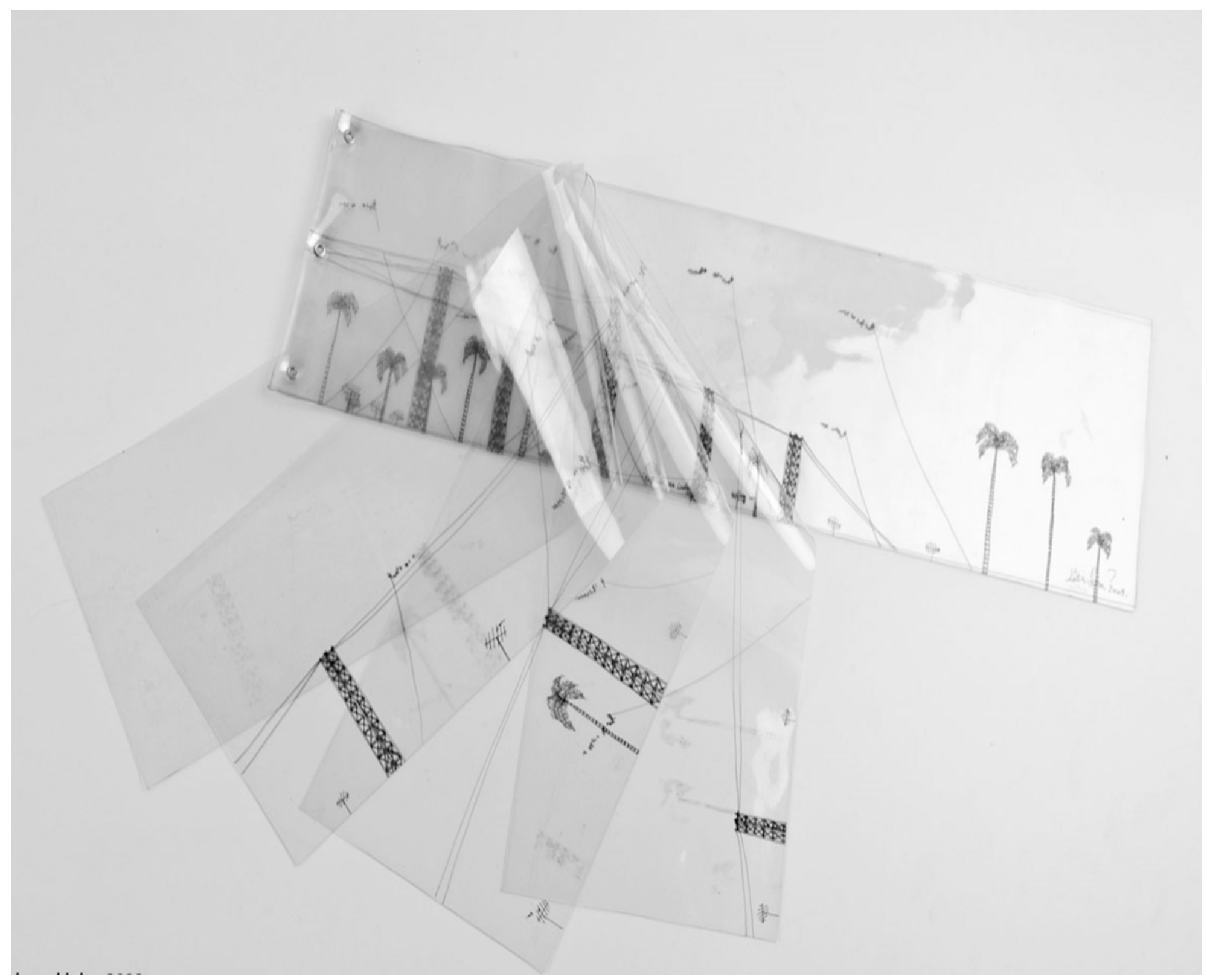


Depois das primeiras experiências com o uso da transparência nos trabalhos anteriores, decidi que poderia ir além. Produzir um livro que fosse completamente transparente, para que apenas as linhas percorressem o espaço. A dimensão do livro também proporcionaria ao objeto um caráter instalativo de interação com o espaço. Desta maneira uma nova camada seria adicionada ao trabalho: a performance do leitor. Assim, como a experiência de atravessar os varais em "Quintais: pipas e varais", a sensação física no embate com o trabalho se tornaria cada vez mais evidente. Não é o conteúdo do livro, mas ele todo. O corpo do livro e o corpo do leitor interagindo. "Andando na Linha" é um livro que considero ainda um projeto, pois acredito ser um trabalho que pede uma dimensão ainda maior para que suas especificidades fiquem ainda mais evidentes. Meu projeto é que ele seja construído em uma dimensão três vezes maior, ocupando uma mesa inteira e sendo apresentado no centro de uma sala, tornando-se assim um livro instalação.

Muitas vezes, como artistas, temos propostas que necessitam de um espaço específico para serem apresentadas ou um tipo de produção que não podemos bancar e, na falta deste, para que de alguma maneira o trabalho exista, é preciso adaptá-lo para uma outra escala. Em alguns casos tais adaptações fazem surgir na realidade outros trabalhos enquanto o projeto continua adormecido. Ele é um ideal ainda não atingido que faz germinar novas perspectivas. Isto aconteceu comigo neste trabalho e em alguns outros, como em "De Passagem", de 2013, publicação realizada durante o período do mestrado. A produção de uma edição para o livro "Migração" foi bastante demorada. Foi preciso pesquisar a forma certa de impressão e escanear página por página. Decidi, então, realizar uma pequena publicação dentro da mesma temática e experimentar o tipo de resultado que poderia obter ao utilizar a técnica de impressão em serigrafia. Pesquisei uma maneira de produzi-la utilizando apenas uma matriz de impressão, pois, como tratava-se de um experimento, não poderia arcar com um custo alto. Busquei uma dobradura que resultasse em um pequeno livreto e criei o projeto a partir de uma folha de papel vegetal, realizando o mesmo tipo de desenho de paisagem contido em "Migração". Assim, poderia ter a prévia do resultado do trabalho. O resultado foi bastante interessante, porém tornouse um outro trabalho. 
Imaginem se Duchamp, ao viajar de Paris para Nova York, resolvesse carregar todos os seus trabalhos consigo. "Quis fazer um livro, ou melhor, um catálogo, que explicasse cada detalhe de meu quadro"12. Ao invés de apenas uma caixa, ele teria de carregar 93 obras em suas bagagens. Quem viaja, mesmo nos dias atuais, sabe que é uma tarefa impensável. Talvez as caixas fossem a solução naquele momento para, de alguma maneira, transportar toda a vivência obtida até ali e não sentir-se começando do zero em outro lugar. Uma maneira de fazer o trabalho existir. Suposições à parte, ele queria projetar algo que pudesse levar consigo, mas, na verdade, o que acabou fazendo foi um novo trabalho. O trânsito pode ser um momento muito produtivo, pois nos obriga à ação. De alguma maneira algo irá mudar, quer queiramos ou não. Seja a paisagem, sejam as pessoas. Ao querer transportar este projeto para outro lugar, o artista cria uma série de outras possibilidades de novos trabalhos. 

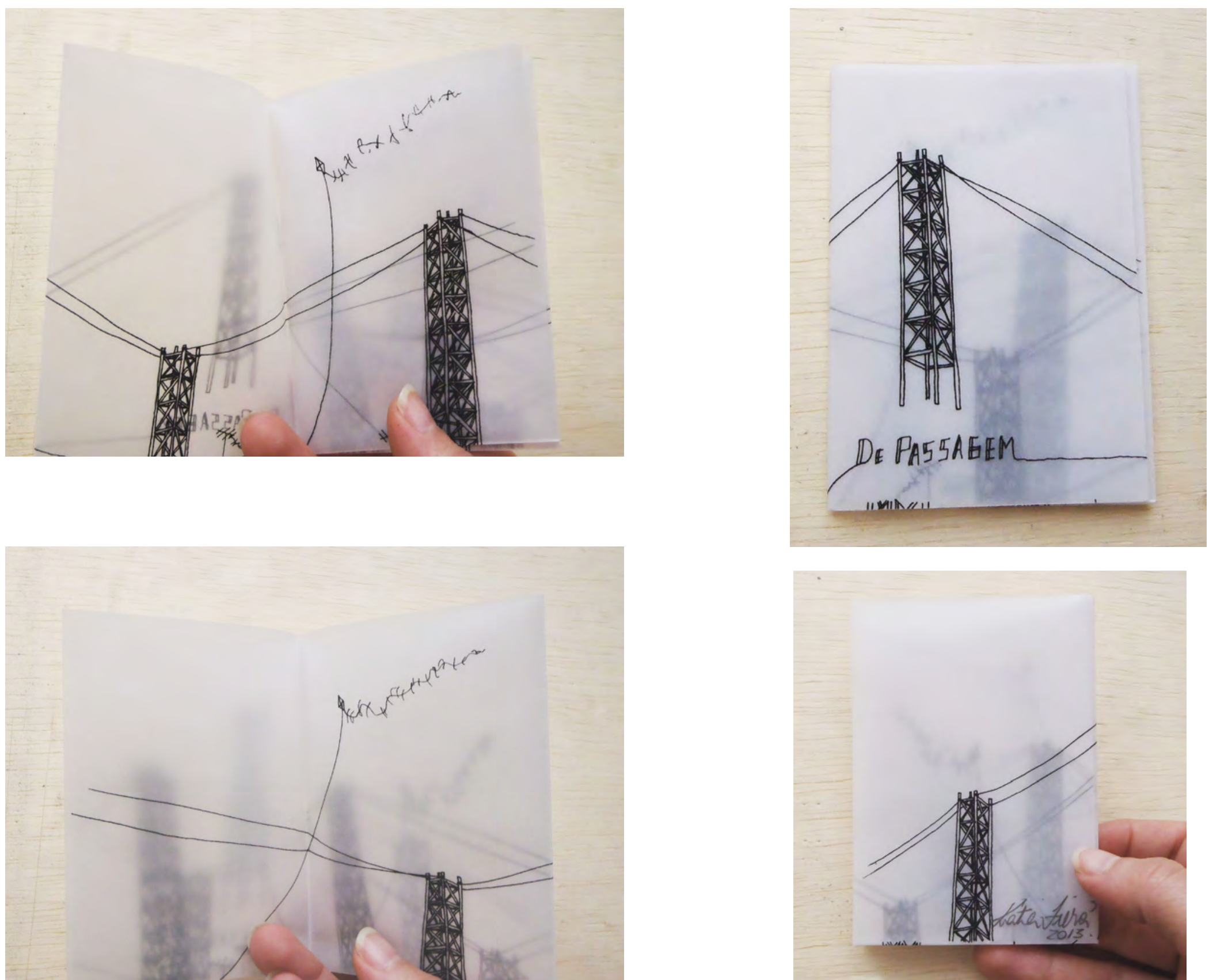

De Passagem, 2013

Serigrafia sobre papel vegetal. $10 \times 07 \mathrm{~cm}$. 
Sempre que produzo um livro, o imagino como objeto artístico. A forma como será apresentado é uma problemática e um desafio constantes. Pensar em como o trabalho será fruído é parte que o constitui. Por consequência, o espaço que irá recebê-lo costuma ser contaminado por sua presença. E a maneira como o observador irá entrar em contato com esse objeto, de que forma irá se aproximar, manipular. O percurso que fará são interesses que impulsionam a construção do espaço.

Em meu trabalho de 2002 intitulado "Castelo Magnólia", procurei tratar as questões de tempo e espaço por meio de uma peça que poderia ser confundida com um brinquedo infantil. O trabalho é construído com pequenos blocos de madeira pintados de branco e desenhados a nanquim. Aparentemente o trabalho se apresenta como o "Jogo do construtor". Porém, ao se aproximar do trabalho, avistamos desenhos de cordas de fugitivos nas janelas, escadas que dão em lugar nenhum e uma série de signos mais complexos do que a simples construção de um castelo. O desenho caminha de um bloco para outro com as peças empilhadas. Conforme os desenhos dos blocos são ordenados, a configuração pode mudar completamente, dando vazão a outros significados. O trabalho foi disposto diretamente no chão, à altura do olhar de uma criança. O público deveria se abaixar para observar o trabalho. Ele também poderia ser manipulado por qualquer um ou ser reordenado; o que raramente aconteceu já que as pessoas estão habituadas a não poder tocar na obra. Na ocasião, eu queria exatamente testar esse limite. O desejo do toque. A vontade do furto, ou a possibilidade de se ignorar que aquilo se tratava de uma obra de arte. O tempo do encontro com um objeto que nos faz acessar memórias de infância é presente neste trabalho. Algo que estava distante, escondido em nosso inconsciente é reconhecido e está ali, ao alcance de nossas mãos. Portanto, ao nos aproximar do trabalho e abaixar, na realidade o que estamos fazendo mentalmente é o percurso inverso, nos distanciando até nossas memórias de infância. Passado e presente juntos. 


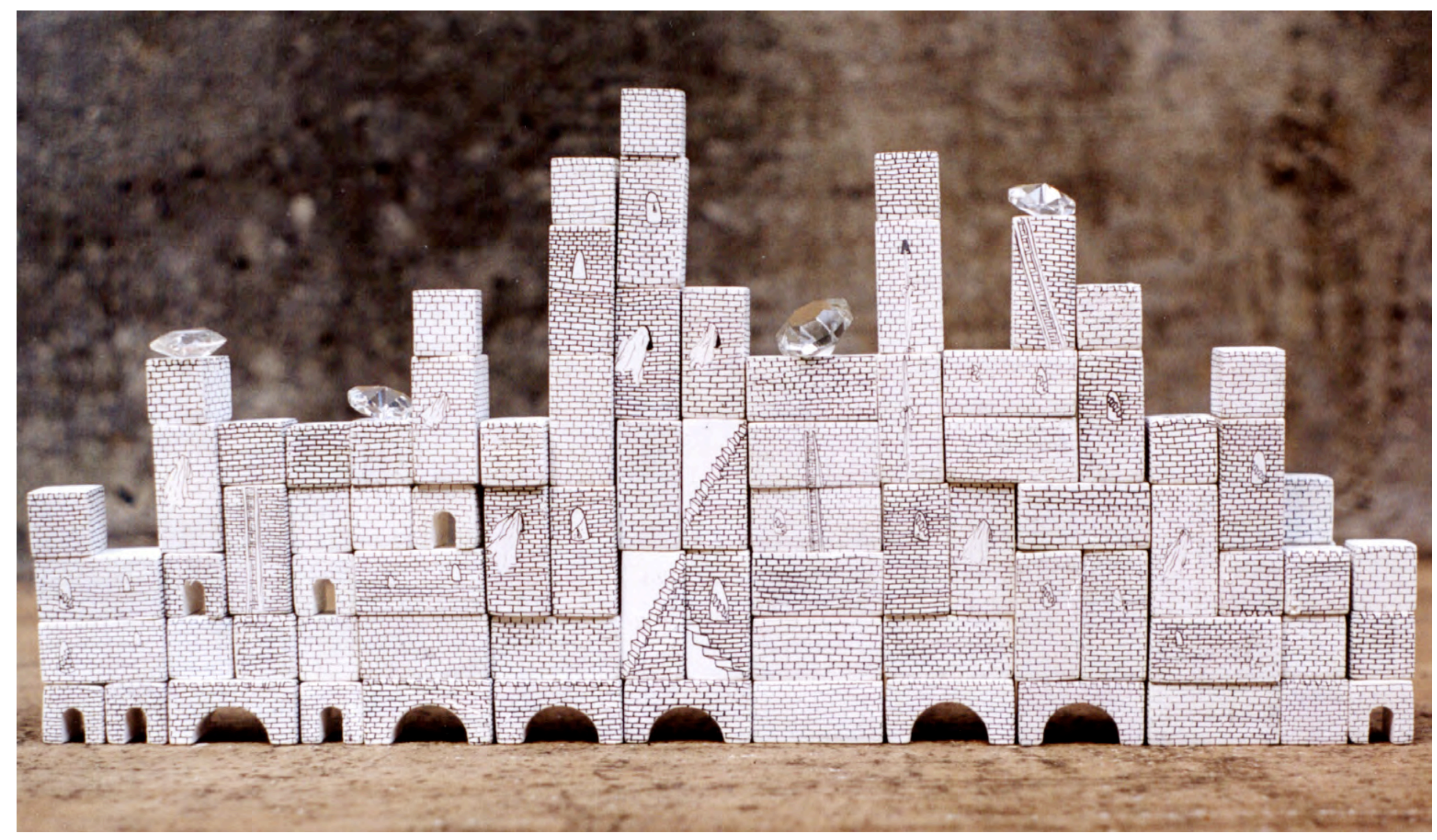

Castelo Magnólia, 2002.

Nanquim e acrílica sobre 80 peças de madeira. 
À medida que fui produzindo, a vontade de edificação do desenho foi ficando evidente. Não se tratava de projetar para depois construir. Eu desejava construir com o desenho. Lançá-lo no espaço. O uso dos planos, o espaço expositivo relacionando-se com o espaço do trabalho. "Castelo Magnólia" já possuía tal elemento por meio do empilhamento das peças e da possibilidade de manipulação do trabalho pelo visitante. Isso será explorado de diversas maneiras no trabalho. De alguma maneira, o processo de construção da obra é evidenciado por isso, fazendo com que o visitante ou o leitor da obra tenha vontade de investigá-la, manipulá-la, tente entender como aquilo foi construído ou de que formas pode ser explorado. Na mesma exposição que participei com "Castelo Magnólia" também mostrei uma série de trabalhos que se apresentavam como jogos de tabuleiro e quebracabeças. Minha intenção com tais trabalhos era a de prolongar o contato do público com o espaço expositivo. Ele poderia ficar lá e jogar ou montar o trabalho. Queria combater a ideia de um espaço opressor que fazia com que as pessoas rapidamente deixassem o ambiente da galeria por não se sentirem à vontade no local. Criaruma relação de afetoé sempre interessante porque faz com que as pessoas interajam de uma maneira menos receosa com o trabalho. O trabalho é um meio de comunicação com o outro.

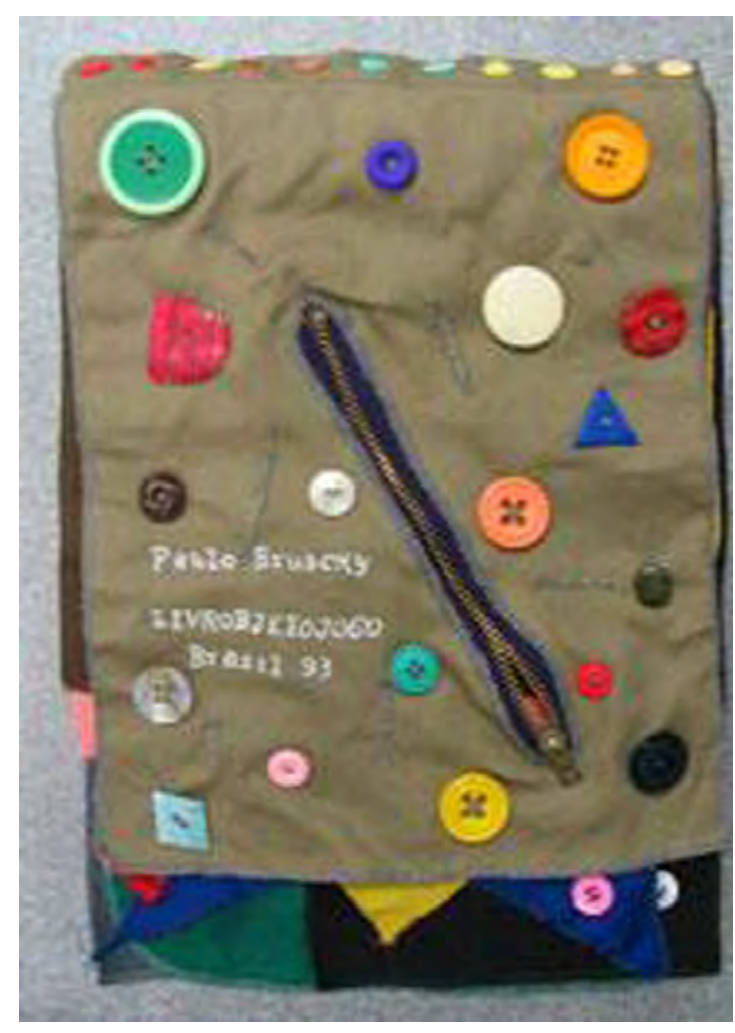

Livrobjetojogo, 1993.

PAULO BRUSCKY

Botõesde plástico, cerâmica e metal, ziper, linha de algodão e costura sobre tecido.

Foto: gramatologia.blogspot.br 
Elementos e signos infantis são recorrentemente utilizados em minha produção como forma de acessar sensações mais sutis. Algo que promova uma experiência física no contato com o trabalho. Talvez por isso tenha me aproximado da produção de livros, por serem táteis e promoverem uma experiência mais prolongada junto ao trabalho. Muitos artistas também utilizaram tais recursos em suas obras, tais como Paulo Bruscky em seu "Livrobjetojogo" de 1993. Neste trabalho, o livro é construído com páginas de retalhos de panos de diversas cores, botões e zíperes que convidam à manipulação.

Embora possuam tais signos infantis, os trabalhos não são direcionados para esse público, mas destinados a qualquer tipo de público e pensados para serem obras de arte. O fato da obra poder ser acessada pela via do lúdico não diminui seu valor ou a eficácia de sua mensagem. Muito pelo contrário, acredito que, na maioria, dos casos é uma maneira de ativar um tipo de percepção que vem sendo deixada de lado na vida contemporânea em função de uma realidade cada vez mais digital.

Assim como nos Gibis de Raymundo Colares e em Solida de Vladimir Dias Pino, a previsão da manipulação da obra e da possibilidade de se construir novas configurações é algo que me interessa explorar nos trabalhos. Durante o período do mestrado produzi um trabalho que chamei de "O mapa da casa infinita". O livro se apresentava, de início, tal qual um mapa dobrado. Ao ser desdobrado, ele nos revela uma casa construída por meio de dobraduras. A cada dobra, um detalhe da casa se revela e nas duas extremidades da casa se encontram as páginas do livro que, ao se abrirem formam caminhos por entre os cômodos e a cada página virada novas combinações se formam como se a casa não tivesse fim. A ideia de um mapa para uma casa infinita, onde sua função de mapa fosse inútil. Como um perder-se em memórias, tentando encontrar um lugar que não está mais lá. Ele foi modificado pelo tempo e, a cada passo em direção àquele local, mais e mais modificações irão acontecendo fazendo com que não se saiba mais qual era mesmo o local procurado. 

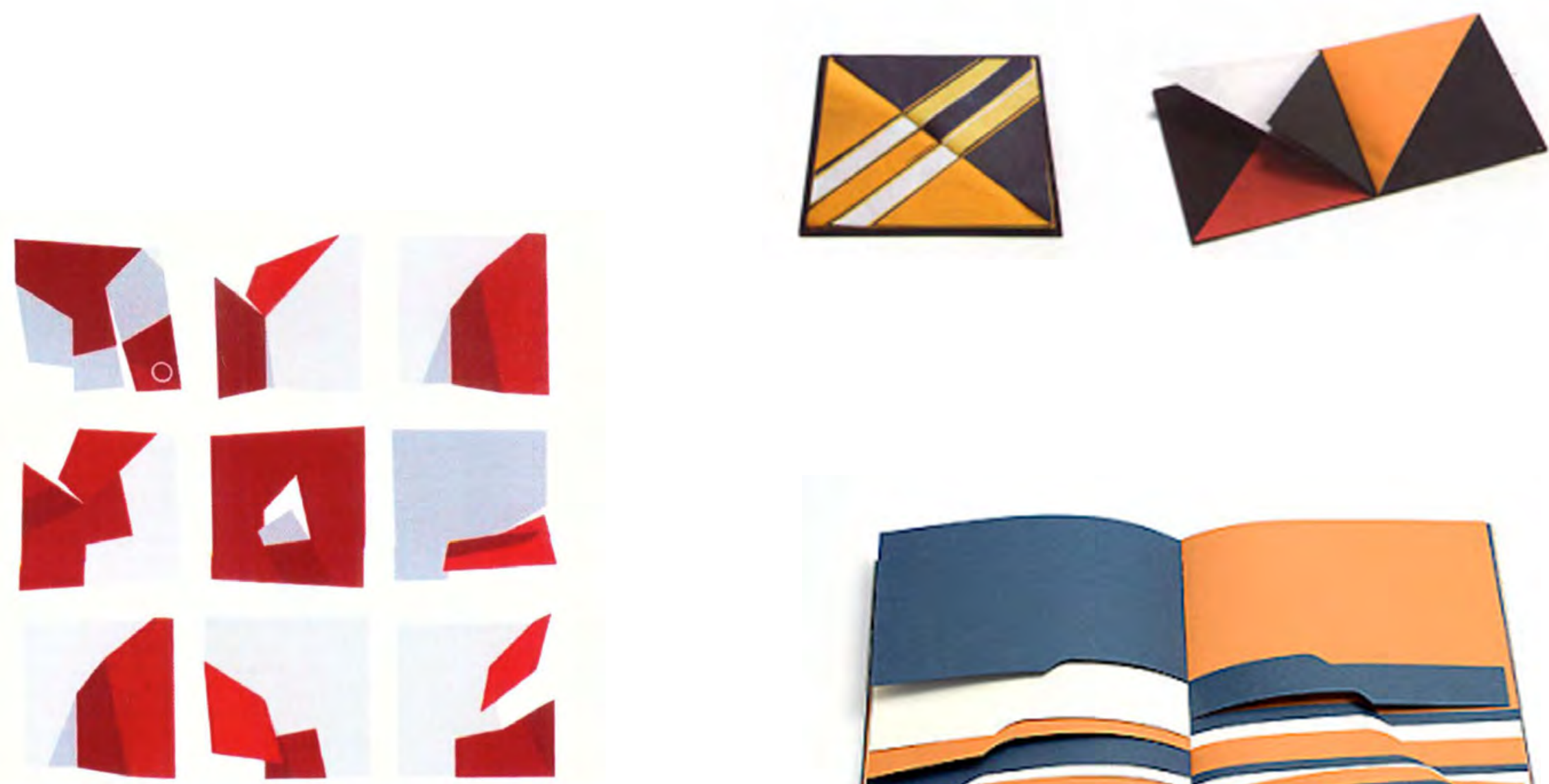

Solida, 1962

Wladimir Dias Pino.

Serigrafia sobre cartão 

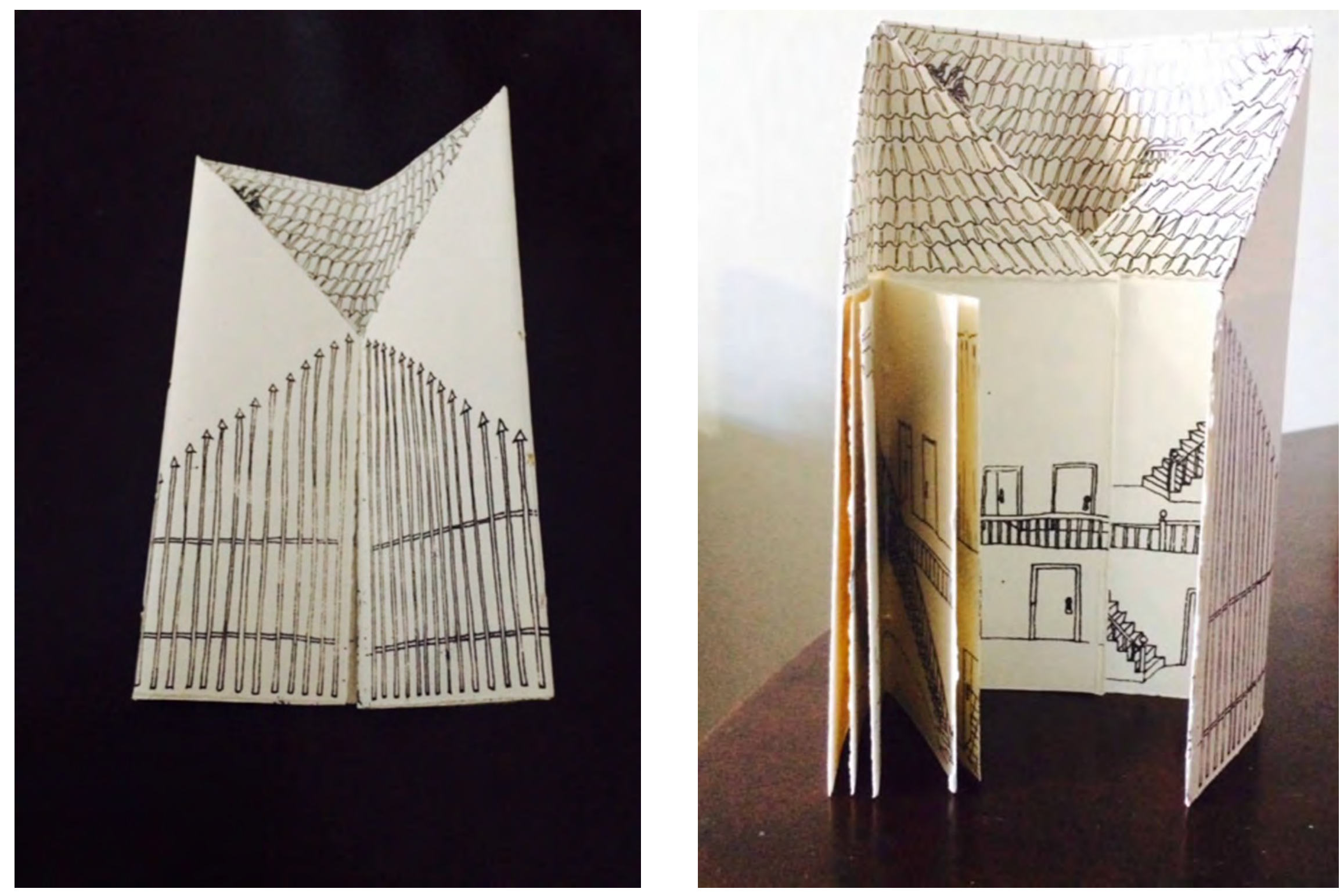


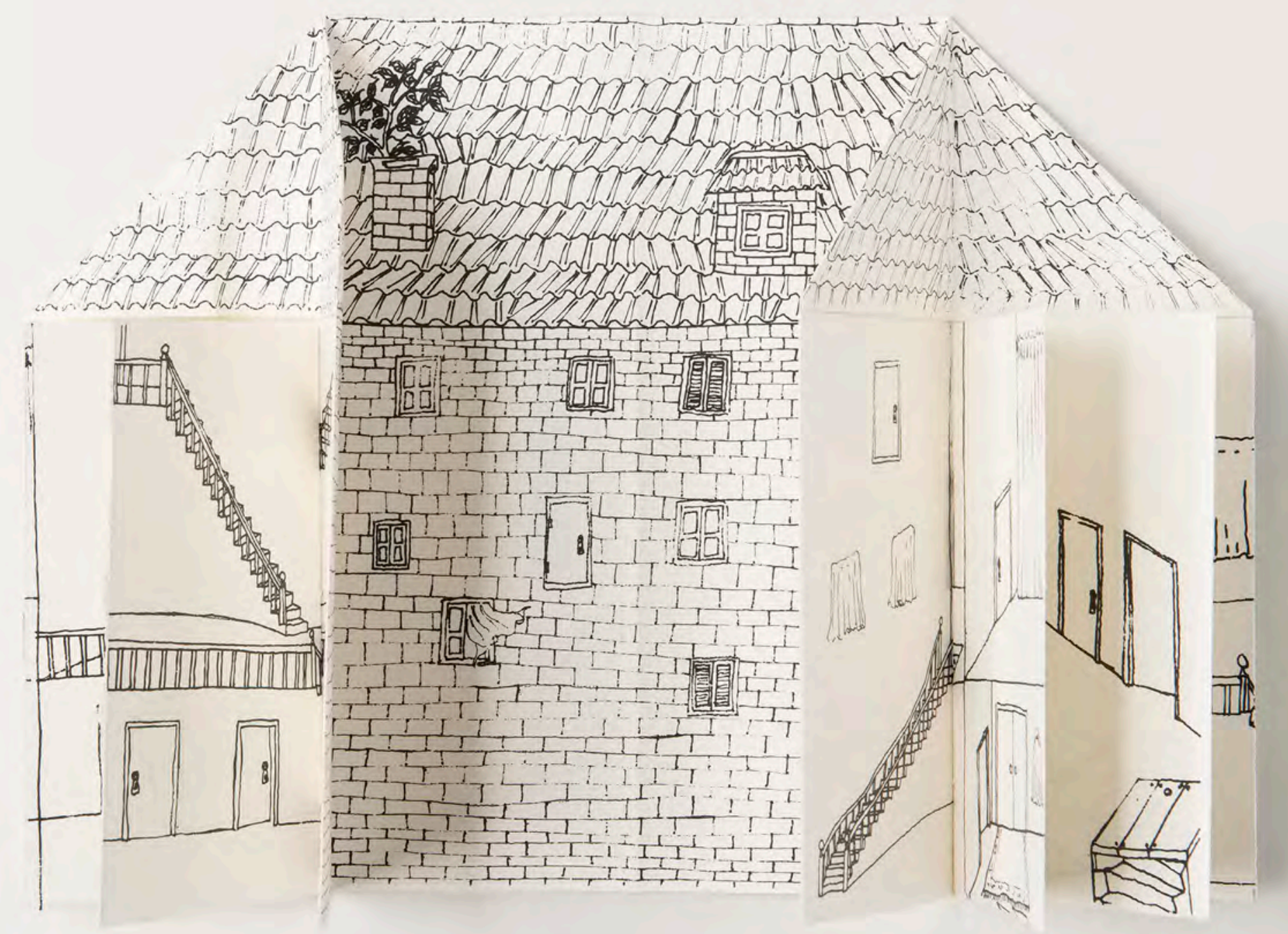




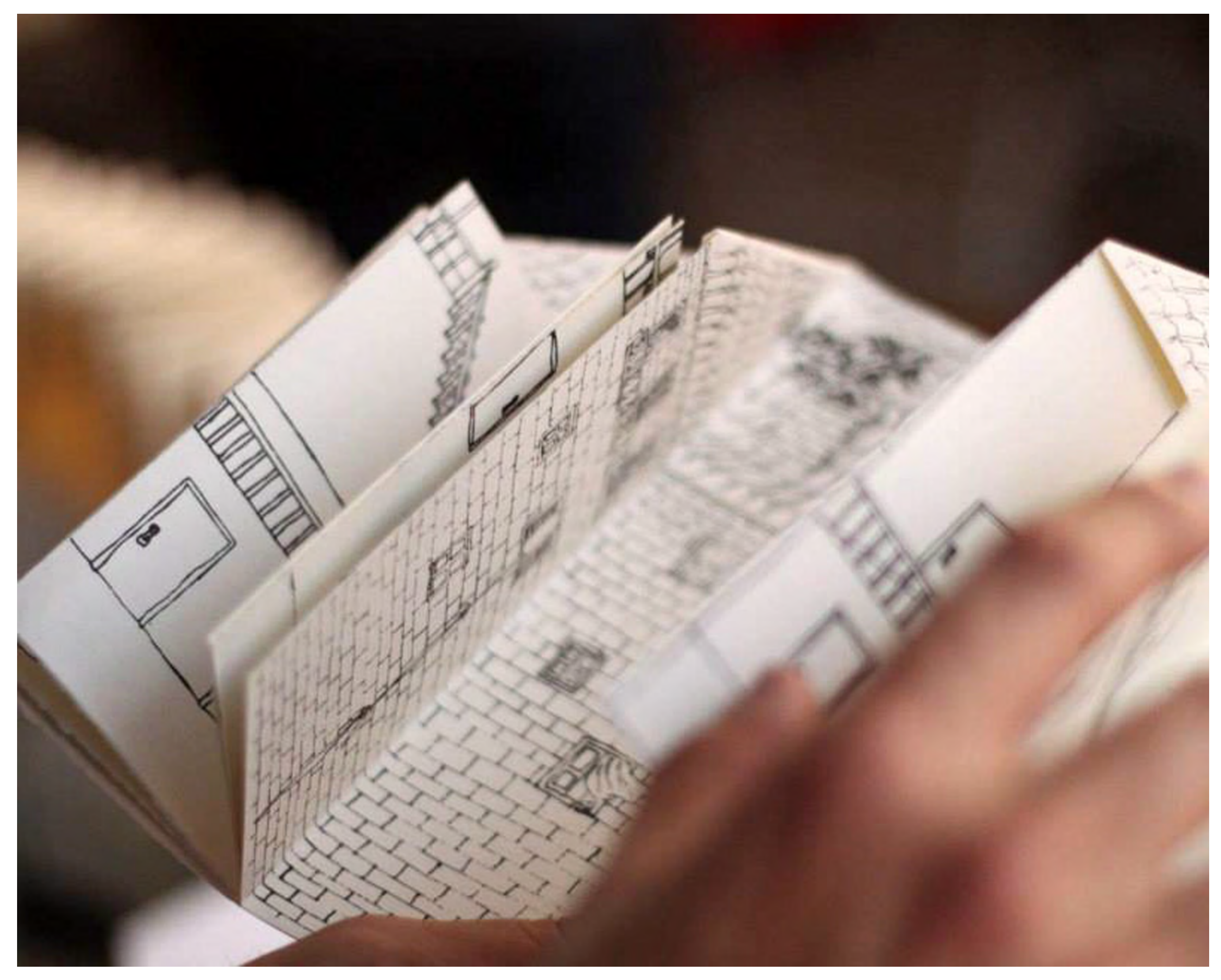


Ao abordarmos o assunto da construção do espaço, seja do livro, seja do espaço expositivo, não podemos deixar de adentrar o espaço da casa. Nosso primeiro "Cosmos", como diria Bachelard. O espaço que nos abriga, o espaço das nossas memórias mais caras e também dos nossos medos mais ocultos. São os espaços da nossa intimidade. Pois sempre existem as lembranças que queremos alcançar e aquelas de que queremos fugir. Fazendo, como dizia Bachelard, uma topoanálise do espaço da casa, ela surge em meu trabalho de diversas maneiras. Existe o perder-se no caminho de casa. A fuga da casa. Os cantos e elementos que constituem a lembrança desse espaço. Mesmo que a casa se pareça com um castelo. Algumas vezes é refúgio e em outras é prisão. Quando pequena, eu imaginava casas em calçadas e dividia os cômodos desenhando com carvão ou pedaços de tijolo no chão. E a casa era a "Planta da casa". Acredito que continue fazendo isso até hoje, buscando maneiras de habitar o desenho.

"Bem entendido, é graças à casa que um grande número de nossas lembranças estão guardadas e, se a casa se complica um pouco, se tem porão e sótão, cantos e corredores, nossas lembranças têm refúgios cada vez mais bem caracterizados. Voltamos a eles durante toda a vida em nossos devaneios."13 
Com "O mapa da casa infinita", também iniciei um processo de busca por soluções que me proporcionassem editar de forma prática minhas próprias publicações. Eu buscava dar conta de produzir meu próprio trabalho sem necessariamente entrar em relações mercadológicas ou de prazos e cronogramas de editoras. Produzir publicações no mesmo ritmo de minha produção artística. Passei então a buscar maneiras de editar com técnicas e materiais que me permitissem realizar todas as etapas e com custo reduzido. No caso de "O Mapa" utilizei apenas duas matrizes de serigrafia para construir todo o livro. Uma para a capa e outra contendo todo o miolo. Produzi cada peça utilizando apenas duas folhas tamanho A3. Encadernei com uma costura artesanal, feita por mim. Deste modo, consegui produzir uma edição de 100 unidades e realizar o trabalho.

A partir de então, comecei a investigar meios de com o mínimo de folhas e impressões realizar as edições. Foi na dobradura que encontrei o melhor tipo de estrutura para multiplicar páginas e potencializar o uso do material. Deveria pensar em que tipo de imagem e como aplicá-la no papel ainda sem os vincos das dobras, prevendo o efeito que a imagem produziria a partir do trabalho finalizado. O que vai dentro, o que vai fora. Há que se projetar tudo antes para não ocorrer erros e nem perda de material. É necessário pesquisar a melhor técnica de impressão a ser aplicada. E foi assim que a arte impressa entrou em minha produção, mais como uma necessidade do que como um gosto pela gravura ou pela impressão. Para isso, o estágio PAE nas disciplinas de gravura da Profa. Dr. Branca de Oliveira me serviram bastante. Durante os dois semestres em que acompanhei suas aulas pude observar melhor a execução das técnicas de serigrafia e litogravura, além de elaborar e realizar minhas publicações com o uso dos ateliês. 
Foi durante a disciplina de litogravura que surgiu o trabalho "Carborundum" de 2014. O título foi extraído do material utilizado para granitar a pedra utilizada como matriz. Como em uma ficção, imaginei que aquele material parecido com um pó de grafite, na verdade era um tipo diferente de formiga muito resistente. Interessante pensar que foi uma técnica criada para grandes tiragens mas que, porém, com o peso das pedras e da prensa e com a dificuldade em se conseguir tintas adequadas no Brasil, acabou por se tornar um processo muito dificultoso e oneroso para o artista daqui, acabando por produzir edições pequenas e trabalhosas. Durante a produção de "Carborundum" iniciei também uma pesquisa mais aprofundada por métodos de encadernação, entendendo que da junção de formatos e encadernação se constituiria a arquitetura do livro. 


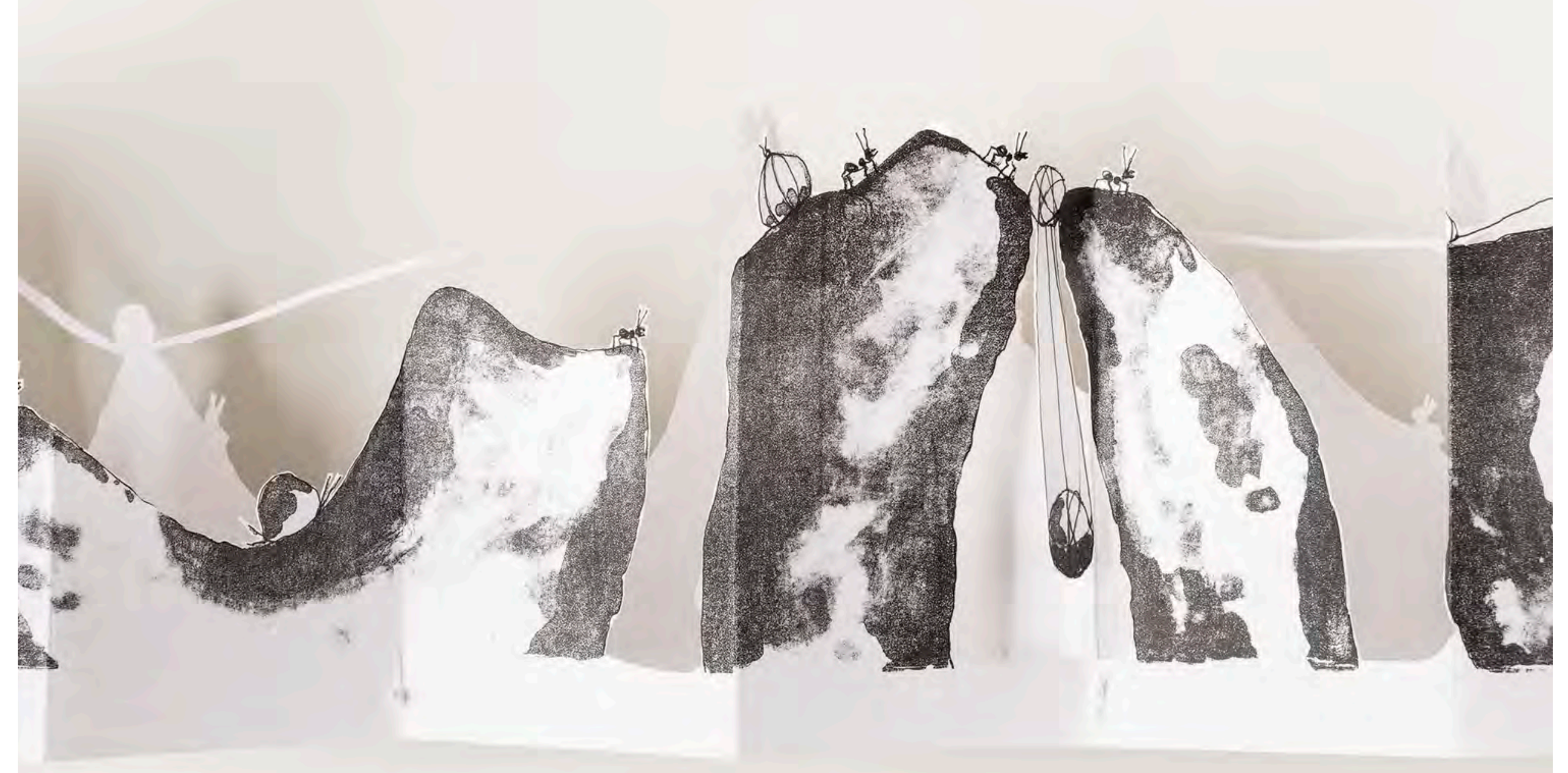




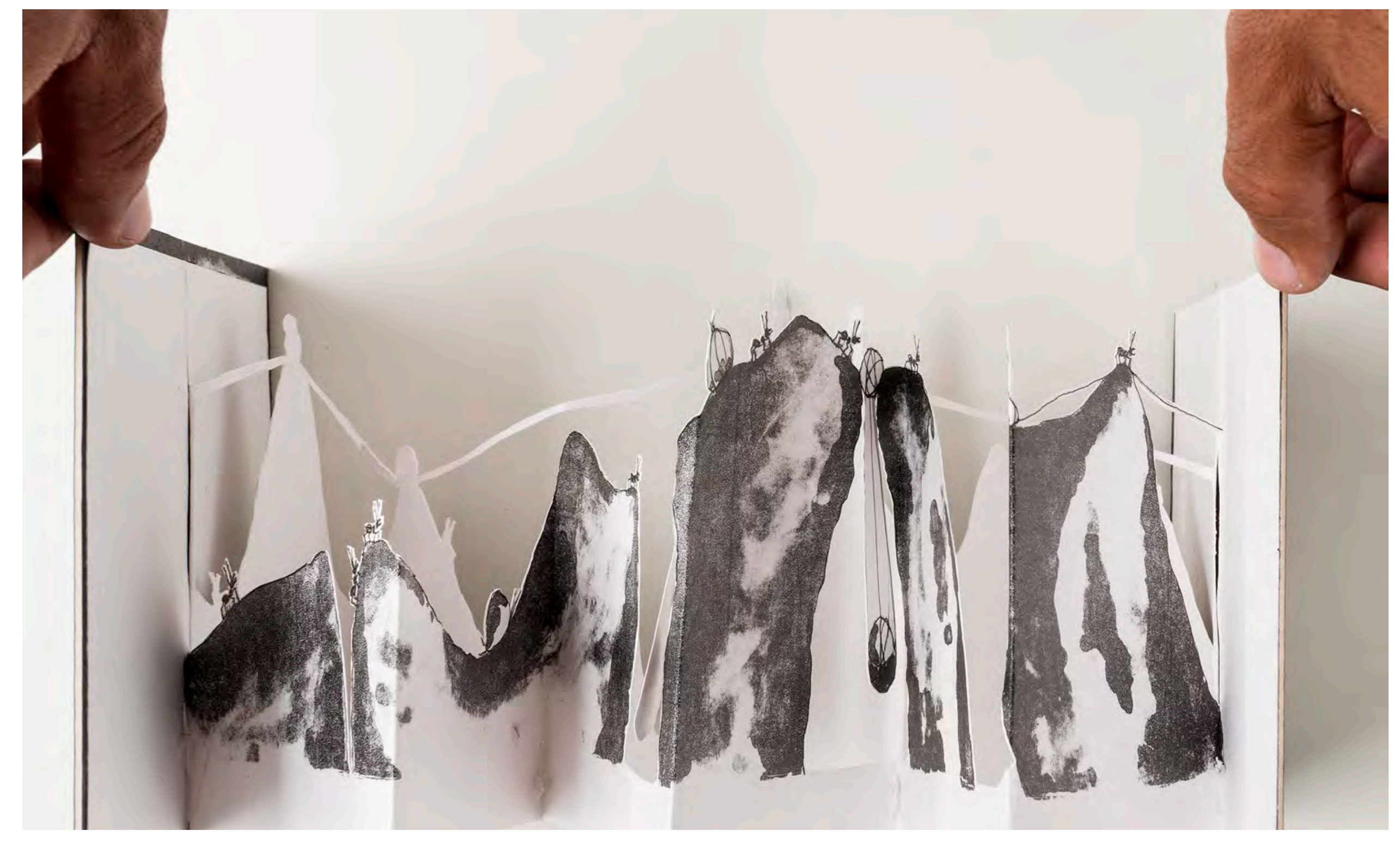

Carborundum, 2014

Litogravura sobre papel, recorte e costura.

13, 5 X 16 cm. (Fechado). 
O assunto do trabalho acabou sendo exatamente este: situações e pessoas com trabalhos muito pesados. Nada melhor para exemplificar isso do que uma formiga que consegue carregar até 100 vezes o seu peso. Pensei em montanhas de pedras por onde formigas, como no mito de Sísifo, produzem um trabalho interminável e aparentemente grande demais para elas. A mancha produzida pelo tuche, um material com que se consegue produzir manchas na litografia tal qual uma aguada, me possibilitaria produzir as paisagens de pedra como nenhuma outra técnica e a ideia de imprimir imagens de pedra com a própria pedra foi algo que me interessou muito no projeto. A dificuldade era que eu não ter uma muitas pedras disponíveis para produzir uma série de páginas e produzir um livro. Outra dificuldade era a de que cada uma das matrizes do ateliê da ECA produzem um tipo de textura. Precisaria pesquisar então um formato de dobradura que me proporcionasse criar a sequência de desenhos que queria utilizando uma única matriz, novamente. Produzi duas matrizes com modelos diferentes de montagens. A primeira teve problemas de gravação e só foi possível produzir uma cópia. A segunda, realizei com um modelo diferente. Como se dividisse a matriz em duas, criando dois desenhos compridos e, também, não foi possível fazer muitas cópias. Com a segunda matriz consegui produzir um livro sanfona, me valendo de dobras, recorte e costura. O resultado me agradou bastante, mas só foi possível produzir 5 exemplares, uma tiragem muito pequena. Decidi trabalhar então sobre a primeira imagem que não tinha dado muito certo. Trabalhei sobre as imagens que havia conseguido imprimir a partir da primeira matriz, escaneei e trabalhei-as posteriormente no Photoshop. A partir da imagem em litogravura, produzi 20 exemplares de uma pequena publicação. Devemos utilizar as novas mídias em favor da arte, foi o que aprendi com este trabalho. Pensar todas as etapas do trabalho proporciona um melhor aproveitamento de cada detalhe, pois tudo no nele é expressão. 
Comecei a pensar na utilização de novas mídias em favor da arte. Um trabalho que surgiu logo depois deste foi pensado e produzido a partir de uma foto de Instagram. Certo dia, saindo da Cooperativa de Catadoras no Glicério, me deparei com uma rua chamada São Paulo. A placa da rua ficava bem em frente a uma construção, o que tornava a visão ainda mais interessante já que quem vive na cidade sabe muito bem que São Paulo é exatamente assim, uma cidade em um eterno construir e desconstruir. Tirei uma foto e no exato momento em que percebi o resultado dela tive a ideia para um outro trabalho. E se passando por essa rua eu pudesse chegar em outra que me levasse a outra, que me fizesse cruzar o Brasil? Um livro passeio. Eu daria um passeio pelas ruas da cidade com nomes de estados brasileiros e tiraria fotos das placas, produzindo assim uma publicação. Confesso que me passou pela cabeça o fato de a fotografia ser uma mídia que não domino, mas como já disse anteriormente, estamos no momento do "faça você mesmo" e me senti à vontade para passear pela cidade tirando fotos com meu celular. E novamente, o percurso aparecia em meu trabalho. "Se essa rua fosse" foi o título que dei à publicação. E eu me via de volta ao caminho de casa. Não a casa em que vivia agora, mas a rua distante que me levava até a casa da minha infância. A rua que me levava a todas as casas de minha memória. A rua que eu percorria sem pressa, olhando as cigarras nas árvores imaginando todas as ruas que viriam dali por diante. 


\section{SE ESSA RUAFOSSE}

Se essa rua fosse, 2015

Serigrafia e impressão digital sobre papel. 

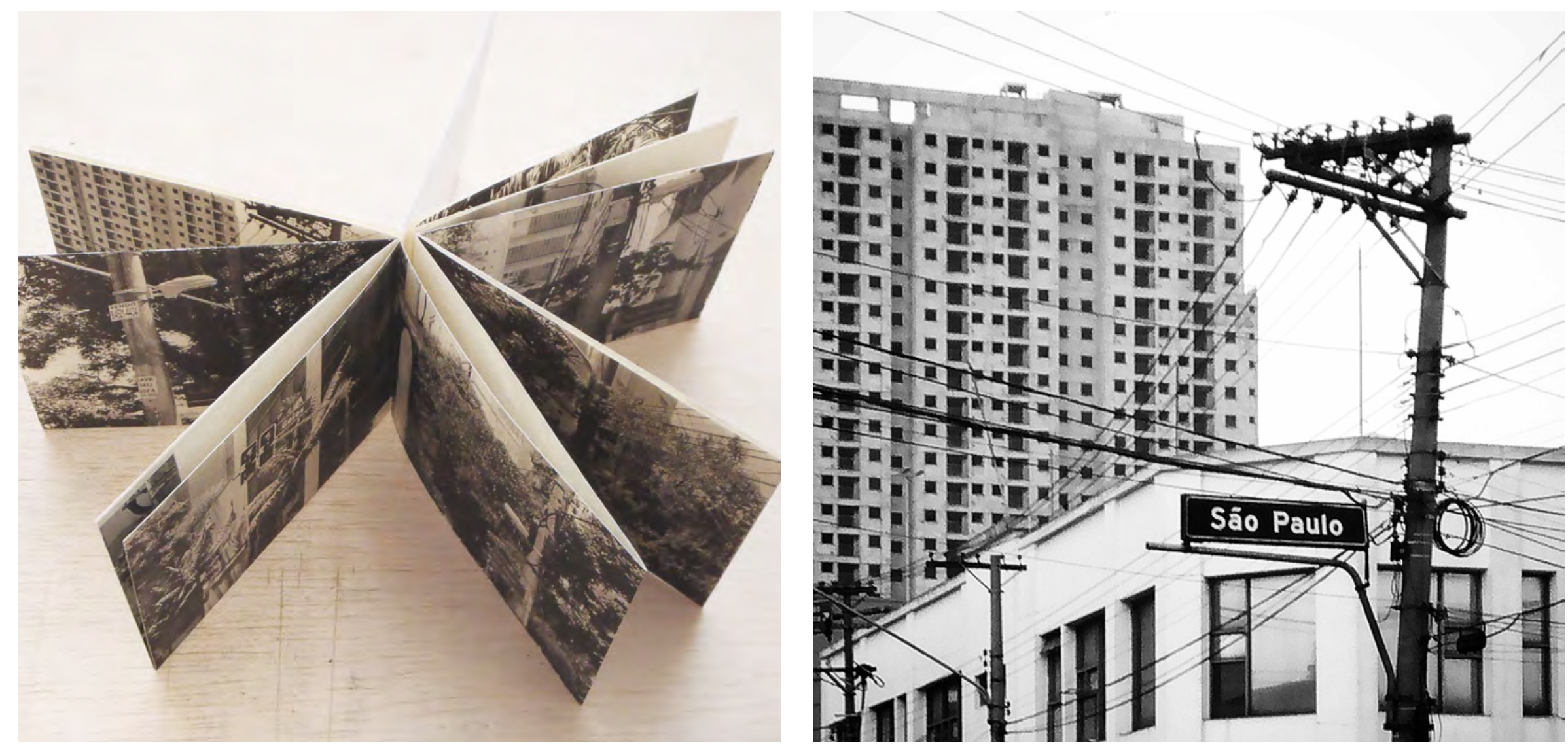
O passo seguinte foi pensar um formato que me proporcionasse um melhor aproveitamento tanto da impressão quanto da construção do objeto livro, de uma maneira que contivesse todos os detalhes do processo de construção evidenciados. Encontrei um papel para a capa que lembrava a cor das placas das ruas, um azul meio metálico e produzi a impressão com serigrafia. Para o miolo, encontrei na dobradura que desenvolvi para a segunda versão de "Carborundum", um formato que produziria um circuito circular, dando uma ideia de passeio. Retirei a cor das imagens, tornando-as preto e branco, podendo assim ter uma impressão menos onerosa. A princípio, queria que essa publicação tivesse a dimensão de uma placa de rua, mas acabei produzindo-a do tamanho de um cartão de ônibus. E assim, em pequeno formato ela pôde existir.

Depois de produzir essa primeira publicação utilizando a fotografia, me senti à vontade para utilizar a técnica novamente caso uma boa ideia me ocorresse. E rapidamente a oportunidade surgiu. Fui selecionada para um edital do Centro Cultural São Paulo para realizar uma residência de dois meses na folhetaria. Os contemplados deveriam realizar uma edição com as técnicas de reprodução existentes no espaço e sem o auxílio de técnicos. O projeto que enviei se intitulava "Corpo de prova" e consistia em criar publicações experimentando tipos de dobras possíveis e utilizando o mínimo de matrizes possíveis de modo a criar publicações. O título foi extraído de um dicionário de arquitetura. Trata-se de um provete extraído de uma construção que é submetido a pressão até a sua ruptura, para provar a resistência do material. Pensei em inserir imagens nas dobras do papel, como se também estivesse submetendo os visitantes do Centro Cultural (que em minha opinião são o que constituem a estrutura do local), isto é, seus corpos, à prova. Relacionando o movimento ou a estabilidade dos que dançam, dos que ficam na fila, dos que estudam, e o movimento da manipulação da publicação. 

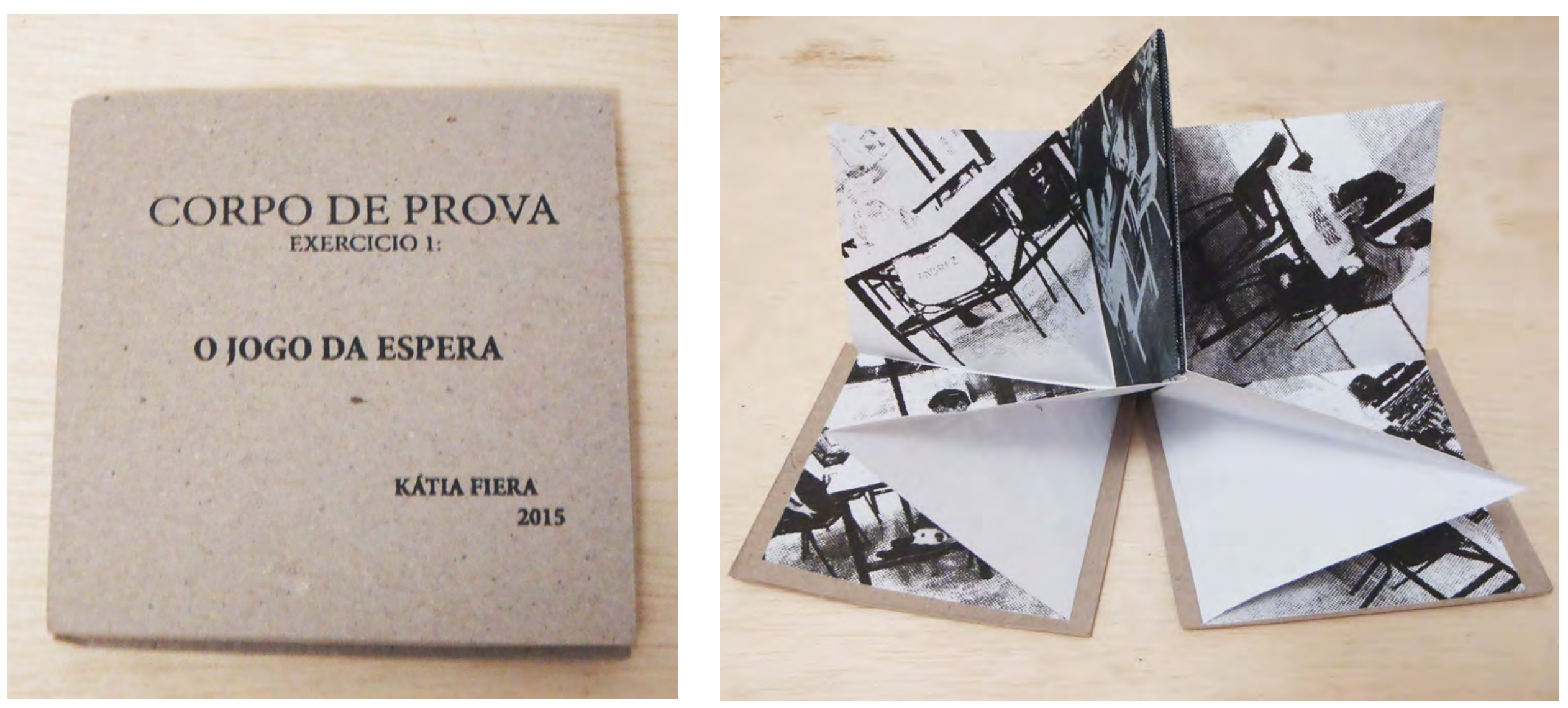


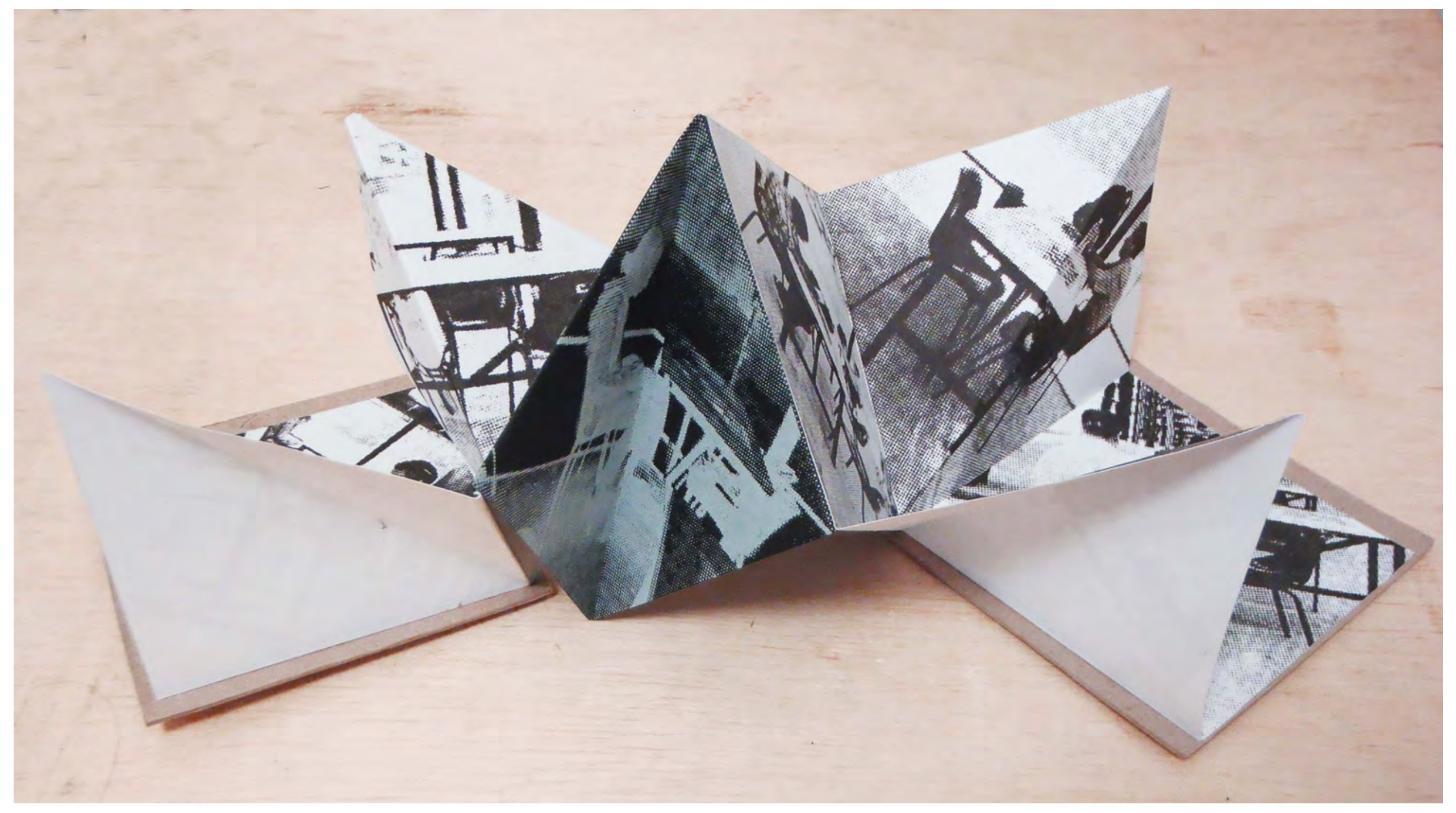

Corpo de Prova exercício 1: o jogo da espera, 2015

Serigrafia sobre papel $r$ dobradura. 
Durante algumas semanas frequentei o espaço e percebi o fluxo das pessoas. Muitos grupos frequentam o espaço para ensaios de todos os tipos de dança. Eles se revezam e se respeitam, cada um ocupando os mesmos espaços em horários e dias específicos. Foi muito interessante perceber o quanto aquele espaço é democrático e ocupado pela população. Funciona como "Oásis" onde as pessoas se sentem bem recebidas, mesmo que seja para dormir em uma cadeira. Pedi permissão para alguns grupos para fotografá-los, o que permitiram sem nenhuma restrição ou pedido de contrapartida. Todos ficaram muito felizes em contribuir para o trabalho. A primeira publicação que produzi foi sobre as pessoas que encontrei sentadas sozinhas nas mesas de xadrez. Em uma tarde, eles simplesmente estavam lá, como em uma performance, cada um sentado em uma mesa sozinho. Como se esperassem alguém para jogar. A princípio pensei em fotografar apenas as pessoas em movimento, mas foi irresistível registrar aquilo. Pensei também que eles não estariam ali sem fazer nada. Eles estavam esperando. Criei então a primeira publicação do projeto "Campo de prova: o jogo da espera". Desde o início, pensei em utilizar a serigrafia como técnica de impressão, por ser a técnica que mais domino e me proporcionar uma certa autonomia, já que o espaço da folhetaria não possui técnicos para auxiliar o artista no trabalho.

Depois das fotos tiradas, transformei as imagens em retícula para poder produzir as matrizes da serigrafia. Foi preciso pensar também em como montar as imagens no fotolito de forma a prever o resultado da posição da imagem depois do papel dobrado. Um verdadeiro jogo de xadrez até encontrar a melhor montagem para o formato de publicação que eu pretendia produzir. Considero "Corpo de prova" um trabalho ainda em processo. Embora tenha produzido uma publicação com edição de 60 unidades entendo que devo produzir ainda mais algumas com as outras imagens que captei durante o período de residência. Portanto é um trabalho ainda em desenvolvimento. 
Em 2014, participei do II Seminário Internacional Arte e Natureza promovido pela USP e fui convidada a apresentar um trabalho na exposição "Naturantes", com curadoria de Hugo Fortes, no espaço da biblioteca Brasiliana. Na ocasião estava frequentando a disciplina de instalação do Prof. Dr. Carlos Fajardo e estava desenvolvendo um projeto chamado "Arquitetando Teorias", onde buscava edificar desenhos com páginas de papel vegetal e criando relações entre esses desenhos, Piranesi e a escultura de Tatlin. Pensei em produzir um projeto especialmente para o evento do seminário. Uma grande bobina de papel, como os antigos Volumens ${ }^{13}$, aludindo à história do livro e desenhado na bobina uma imagem que tivesse relação com algum dos meus livros preferidos. A exposição aconteceria no espaço da Biblioteca Brasiliana. Por isso, acreditei que as relações seriam pertinentes.

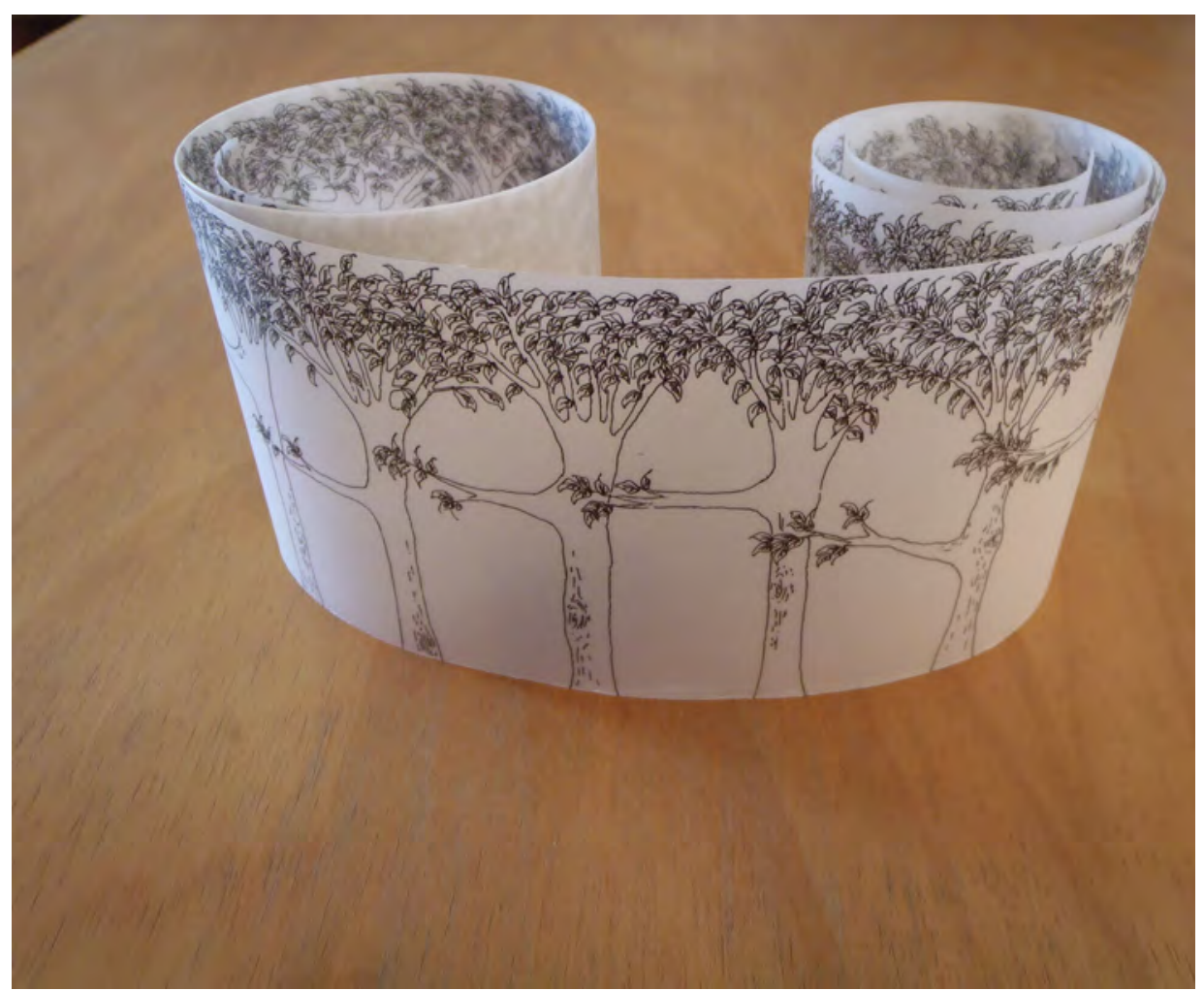

Original de Acolá. A partir deste desenho que posteriormente foi vetorizado para possibilitar a ampliação da imagem sem perda de definição.

13 Khartés ou Volumen, como era chamado pelos gregos foi o primeiro tipo de livro existente. Antes deles a escrita era feita em argila ou mármore. Consiste em um cilindro de pergaminho que era desenrolado a medida que era lido e chegava a ter 7 metros de comprimento. 


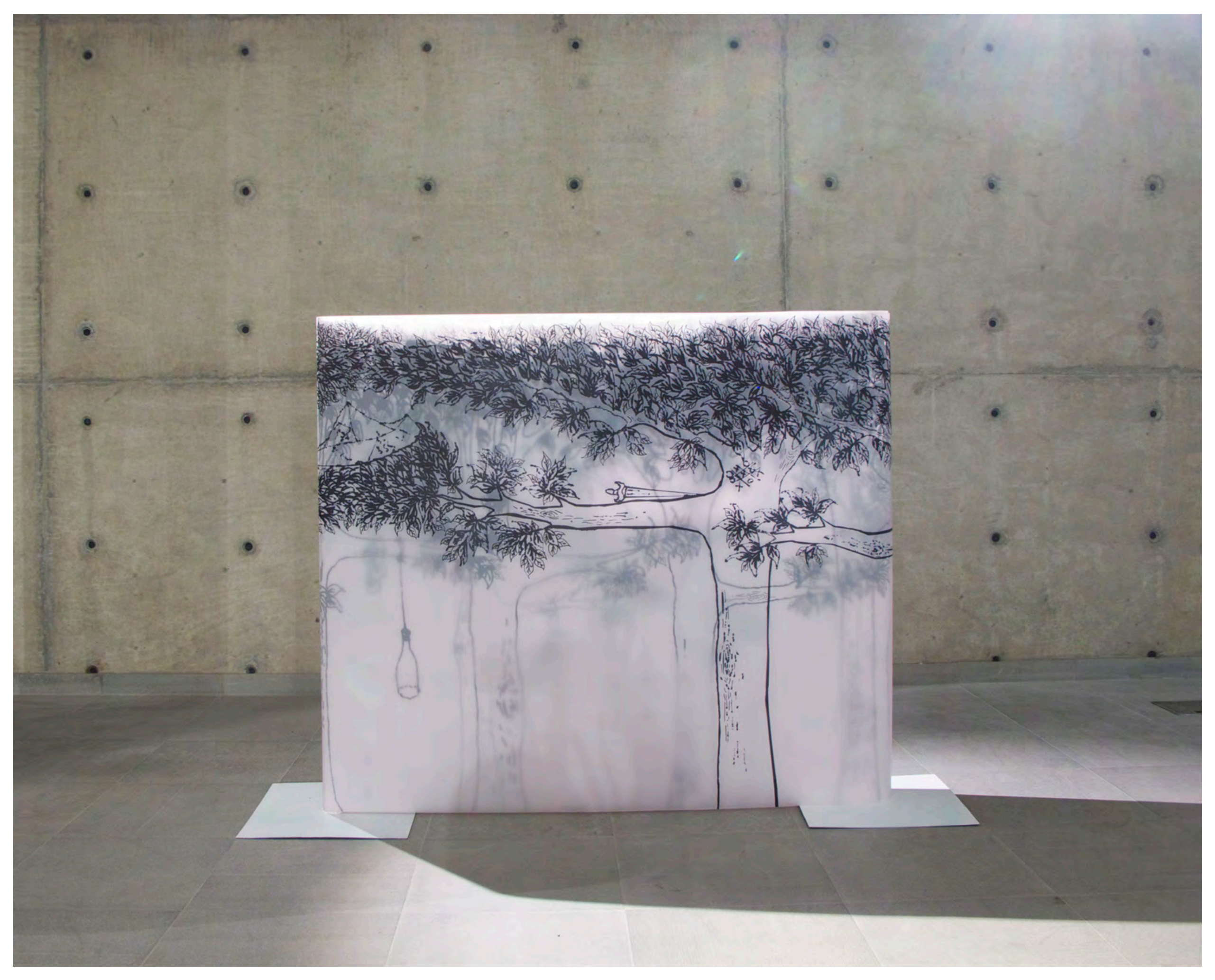




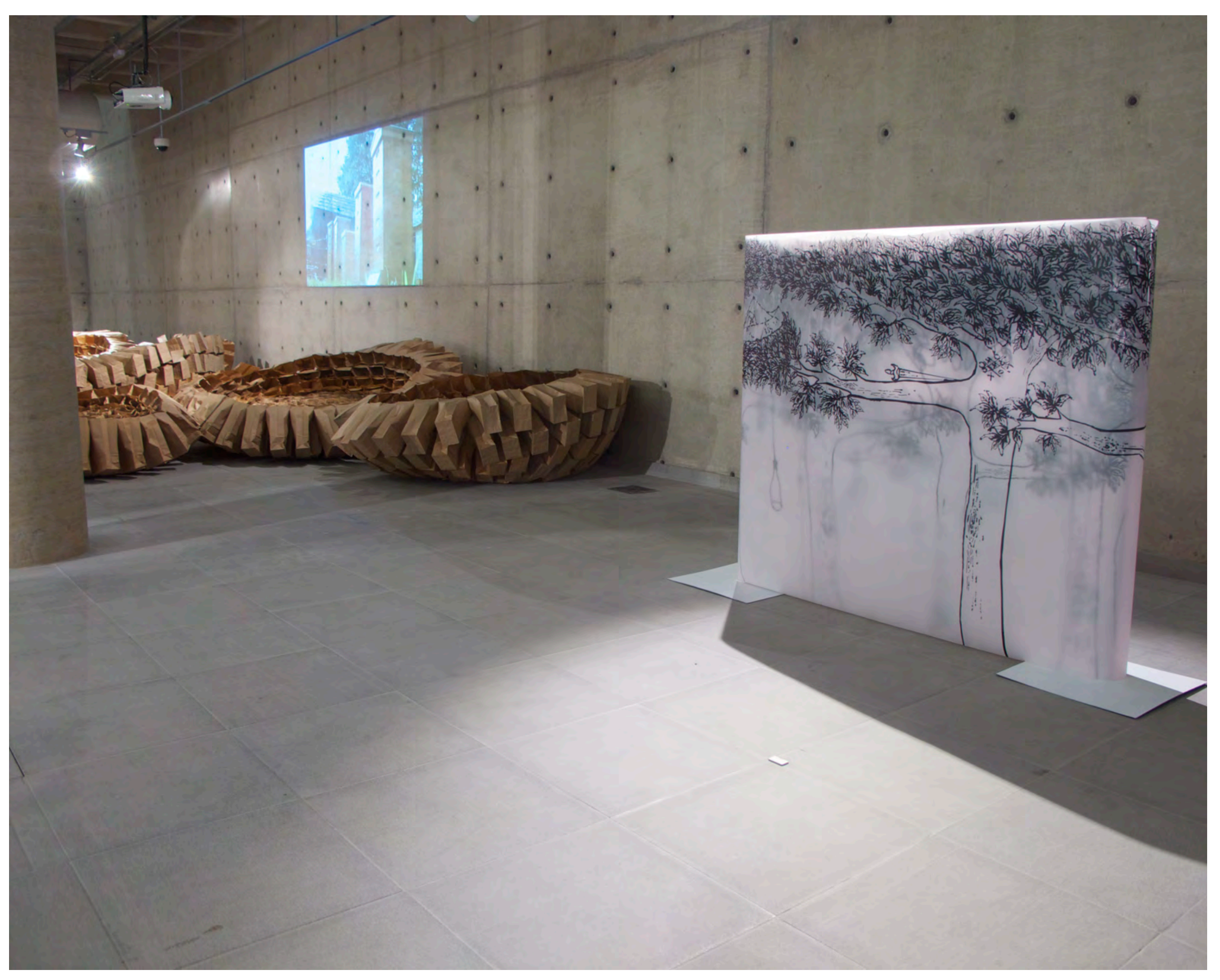


Como o seminário era sobre Arte e Natureza, pensei em uma série de árvores, uma referência ao livro "O Barão nas Árvores" de Ítalo Calvino, um dos meus preferidos e que me remete à minha própria infância, quando subia em árvores no Pará. Criei o original em pequena escala, uma sequencia de árvores com brinquedos pendurados, como se tivessem sido esquecidos ou deixados de propósito, como armadilhas. Escaneei o desenho e vetorizei para poder ampliar a dimensão sem perder a definição da imagem. A impressão foi feita com um processo UV e foi utilizada uma bobina de 10 metros. O que não previa era que o papel vegetal em grande dimensão pesasse demais. O trabalho não ficava de pé. Precisei então elaborar duas bases de metal cilíndrico onde enrolei a bobina de papel. A bobina de pé no espaço acabou se transformando em um objeto, que também era um desenho e que também era um múltiplo. Se for apresentado em um espaço menor, ocupando o centro da sala, o visitante poderá circular por toda a obra e talvez até ele venha a ser uma instalação. E isto me leva ao capítulo seguinte: Qual seria o espaço do papel e o papel do espaço na construção do livro de artista? 


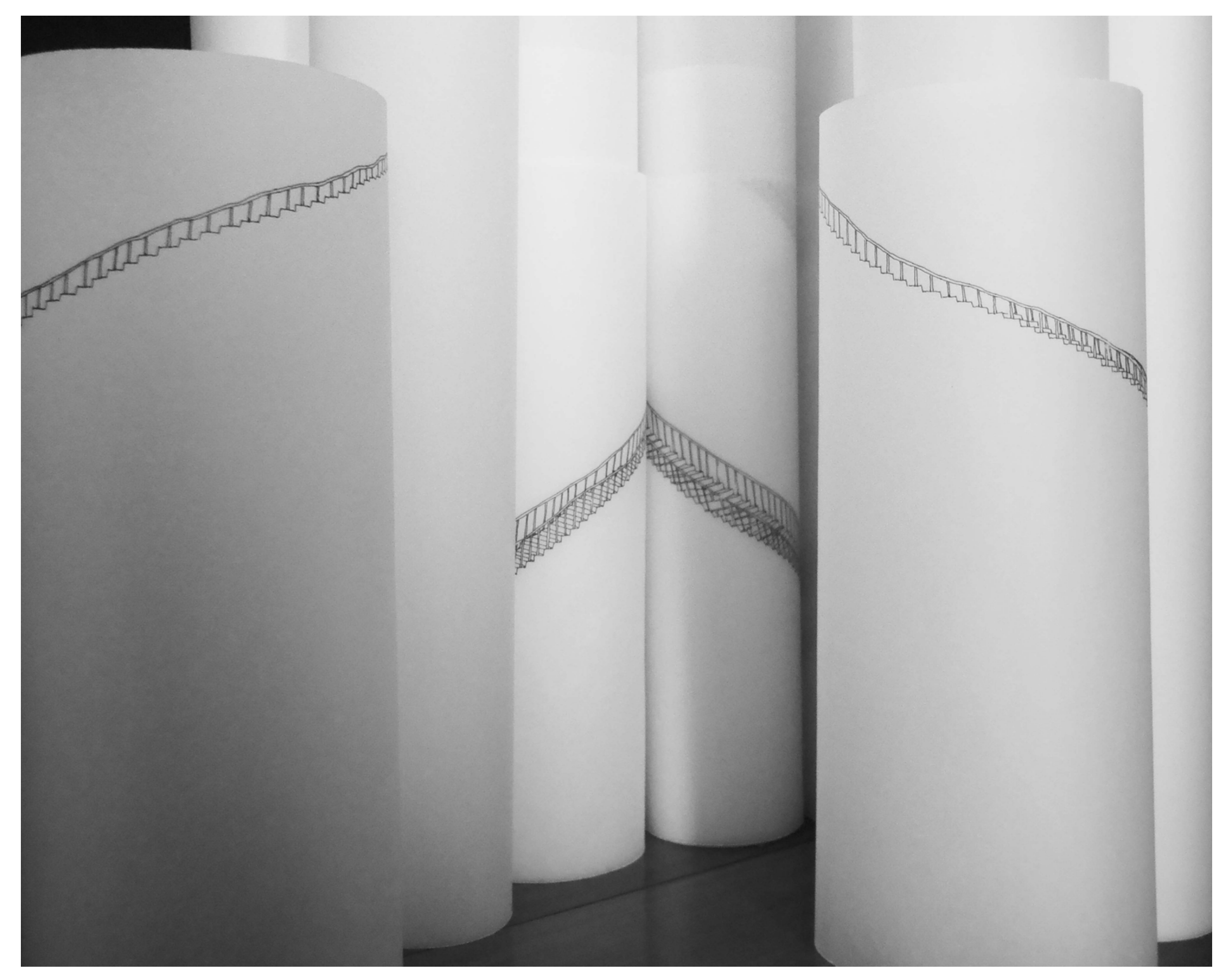




\section{Capítulo 3}

O Espaço do Papel e o Papel do Espaço

O espaço de uma folha de papel pode conter o universo, como já nos mostraram Lygia Pape e uma série de artistas a partir dos anos 1960. Uma grande contribuição do grupo neoconcretista para a arte brasileira foi buscar a integração do espaço da obra com o espaço real. A integração entre o lugar da arte e o mundo ${ }^{14}$. Pois afinal, não seria a mesma folha que ora se transforma em bandeira, ora em roupa no varal, ora em pipa voando no ar. Ora vazios, ora cheios, todos são delimitadores de espaço. O artista que articula o espaço, o faz seja ele qual for.

Didi-Huberman nos exemplifica estas experimentações em relação com o espaço como duas crianças brincando com um lençol, que ora vira sudário, ora bandeira, casa e vestido. Ou o brincar com cubos. "O cubo se torna, nas mãos da criança, um objeto a lançar tão fragilmente quanto um carretel: ele rapidamente semeia em seu quarto uma desordem disseminada - e não obstante constrói. Pois, tão logo lançado, o cubo se fixa e se imobiliza em sua calma estatura de monumento. Num certo sentido, ele está sempre caído, mas poderemos dizer igualmente que está sempre erigido." ${ }^{15}$ Pois então, o mesmo cubo que se apresenta no chão em forma de jogo pode ser ampliado e ocupar uma sala e as relações se inverterem. Ao invés de nos abaixarmos e buscar o que acontece com as pequenas peças, elas podem tomar todo o espaço e, quando percebemos, nós é que estamos dentro do cubo e a dialética se inverte. Assim como a Alice de Lewis Carrol, podemos perceber que as mudanças de escala podem alterar completamente nossas percepções dos espaços e nosso modo de nos relacionar com tais lugares. Ocupar o espaço, seja ele qual for, tem relação com a percepção que se quer atingir. 


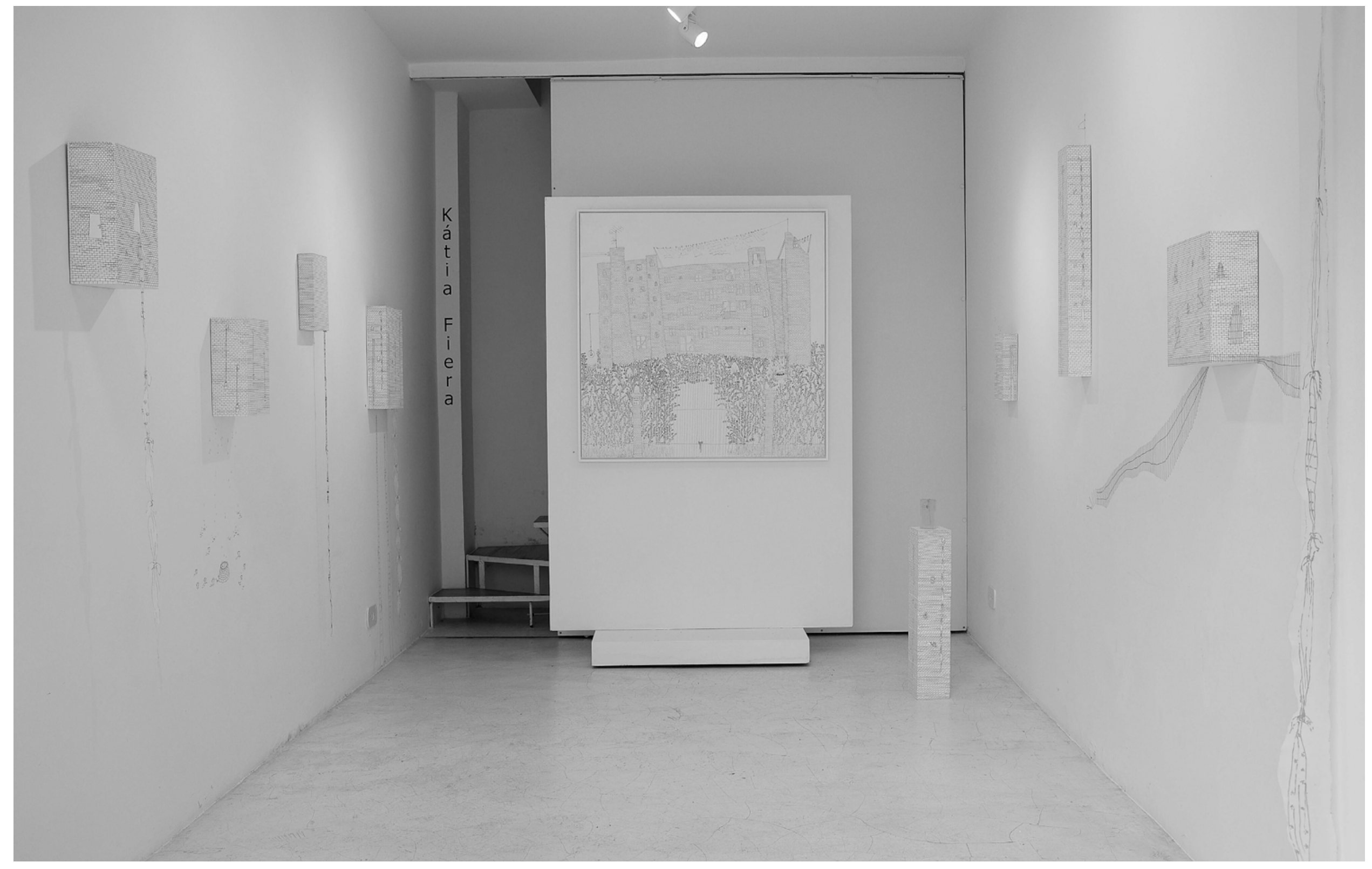

E quem quiser que conte outra, 2009 
$E$ os blocos pequenos que faziam com que a sala se ampliasse e que nós também nos sentíssemos grandes ao nos abaixarmos para perceber melhor o trabalho em "Castelo Magnólia"; em "E quem quiser que conte outra" se transformam em sala e nós é que estamos passeando em meio aos cubos. A própria sala é um grande cubo branco. Os cubos agora posicionados em vários pontos da sala, paredes, piso, narram histórias que acontecem ora em seu interior, ora no exterior. Repletos de lacunas a serem preenchidas pela imaginação de quem os observa.

Em 2009, realizei uma exposição individual em uma Galeria de São Paulo chamada D-Concept. O espaço tinha um formato de cubo branco. Instalei os trabalhos em alturas diferentes e, a partir do desenho contido nas caixas, eu realizei interferências nas paredes do espaço. Os desenhos saíam das caixas e percorriam as paredes até se aproximarem de alguma maneira até a próxima caixa. Isto criava um percurso para o olhar do visitante que, em alguns momentos, sentia necessidade de se aproximar das frestas contidas nas caixas para poder observar o que continham.

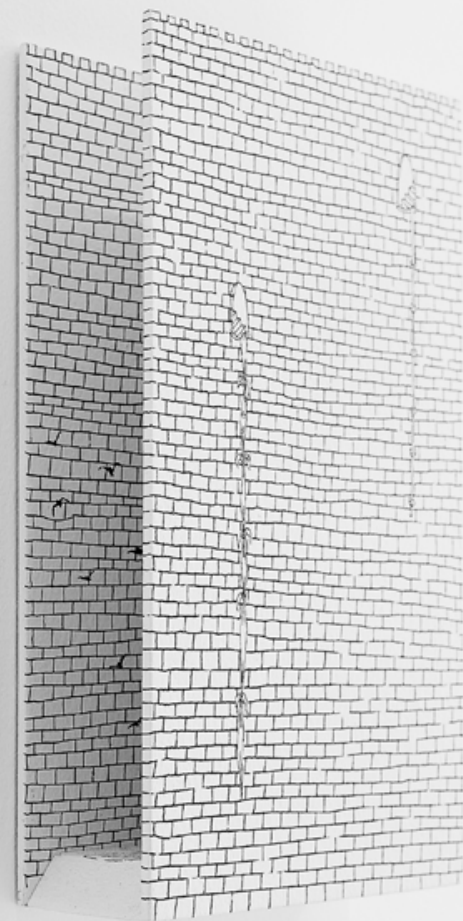


Algumas das caixas tinham formatos parecidos com livros. Outras, torres e castelos. Nos desenhos, assim como em "O Castelo" de Kafka, você percorre os ambientes sem nunca chegar a lugar nenhum. É como se sempre estivesse chegando no exato momento em que alguém deixava o ambiente, deixando algum tipo de rastro como uma corda de fuga, ou uma janela aberta. Sempre um local que te leva a outro local que dá em lugar nenhum. E por que não folhas soltas que podem se agrupar e formar uma imagem só, como a copa de uma árvore, ou podem ser soltas ao vento e tomar vida própria? Trabalhos que funcionam como uma instalação, porém que podem existir individualmente.

O espaço de uma sala pode ser tratado como o espaço interno de um livro. Podemos segmentá-los, de forma a criar novas relações e novos espaços. Acrescentar ou retirar páginas. No caso de artistas como Edith Derdyk, Liliana Porter, Erick Beltrán, e entre eles eu me identifico, as relações no interesse da obra gráfica suplantam o simples gosto pela literatura ou pelo livro como objeto de fetiche e, podemos identificar claramente uma experimentação formal do espaço livro e essas relações continuam quando o trabalho se expande para o espaço do mundo. Não se tratando portanto de uma transposição do trabalho em livro para um outro espaço. Tudo é espaço. O que muda é nossa relação física com tais trabalhos.

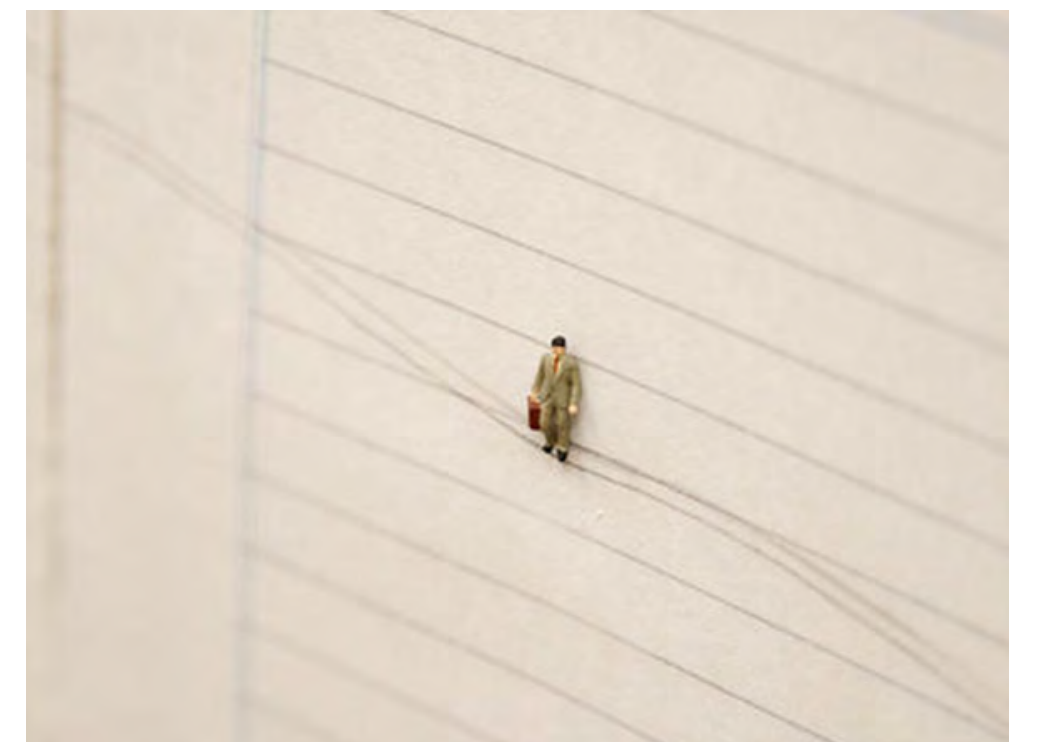

Viajero, 2013 LILIANA PORTER.

Miniatura e grafite colados sobre folhas de papel. 63 X $96 \mathrm{~cm}$. Foto: lilianaporter.com 


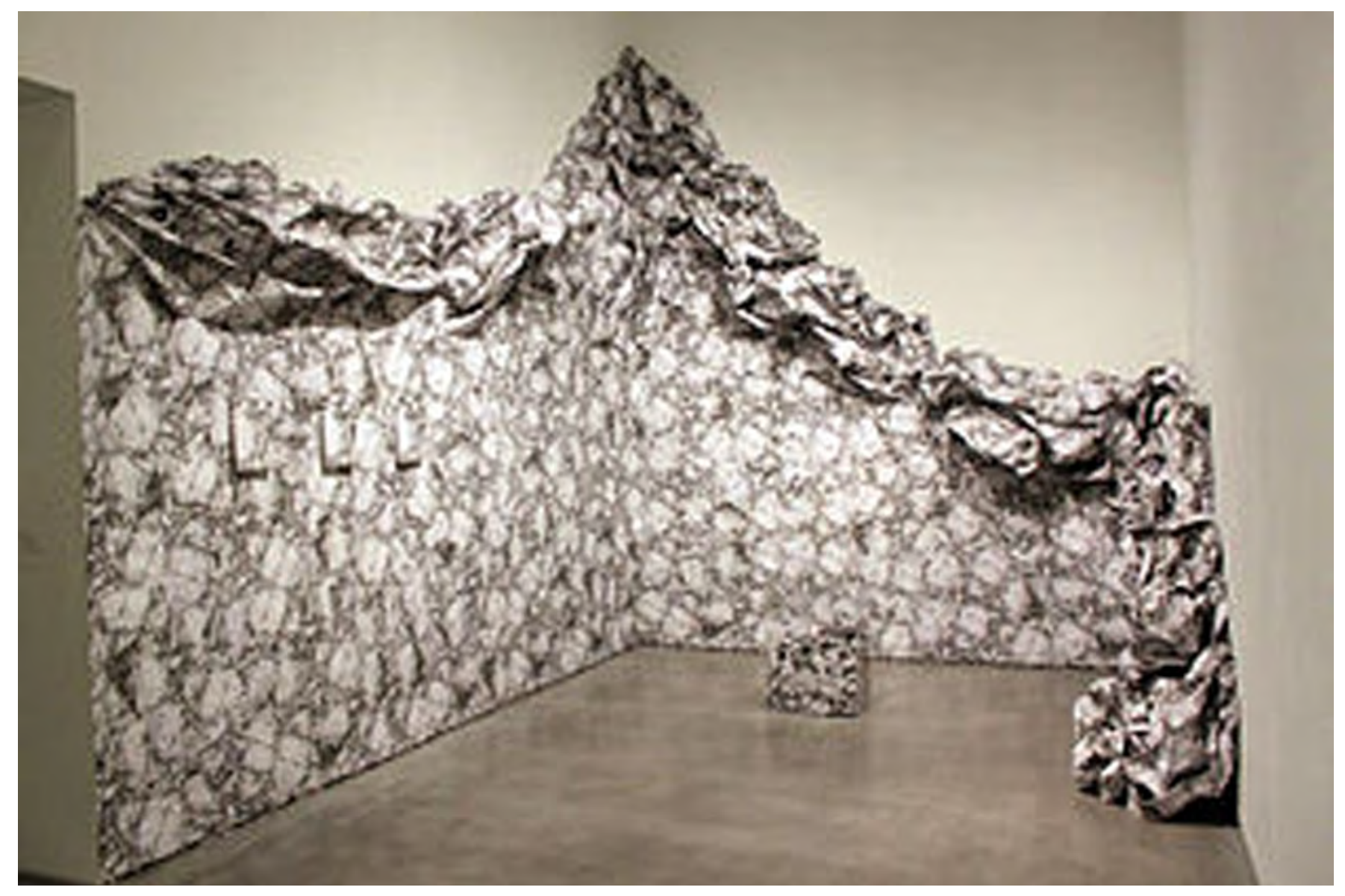

Wrinkle Enviroment Tnstallation I, 1941. LILIANA PORTER.

Papel de parede, caixa de acrílico e parede.

Foto: lilianaporter.com 
Liliana Porter é uma artista que trabalha muito bem esta variação decampoe possuiuma profundarelaçãocomas miniaturas. Possui trabalhos onde miniaturas de figuras utilizada em projetos de arquitetura se relacionam com a folha de papel como se esta fosse uma parede, uma sala, enfim sempre um espaço que transforma e brinca com as dimensões. A figura em miniatura transforma a folha em uma parede imensa a ser preenchida ou uma pedra em montanha. Nos remete à nossa pequenez em relação ao mundo.

Quando a artista se lança no espaço, ela nos transforma em uma de suas miniaturas, fazendo com que o papel se amasse a partir da parede e dê a sensação de que seremos engolidos pela sala e de que, na verdade, toda a sala é apenas uma folha se amassando e com ela vai-se o mundo. Em um outro trabalho, "To be wrinkled and thown away", Liliana propõe que a instalação seja construída por uma ação proposta ao público. A artista expõe uma série de espécies de blocos de papel e propõe ao público que o arranque, amasse e jogue no chão. $\mathrm{E}$ a instalação vai sendo construída à medida que a exposição é visitada. Uma construção por meio do acúmulo de papel e do fluxo de pessoas. A sala é o cubo vazio a ser preenchido pelas folhas amassadas. Portanto, aqui é possível

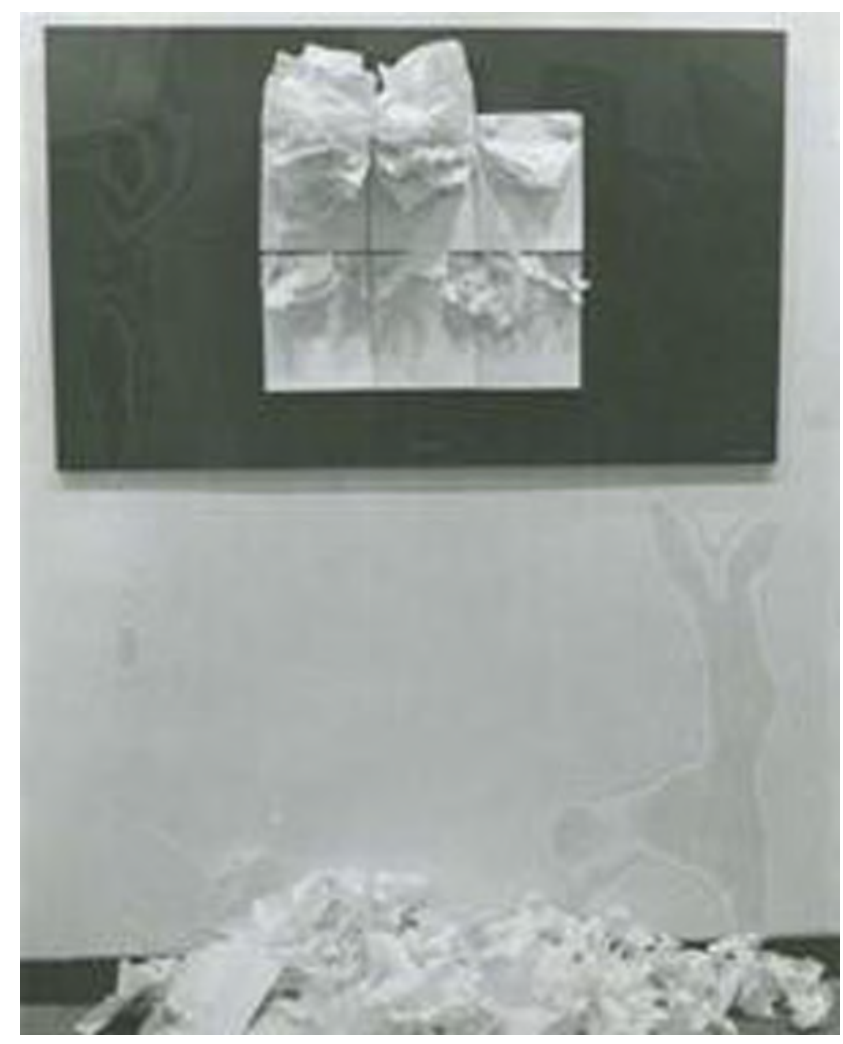

To Be Wrinkled and Thrown Away, 1969/2008 LILIANA PORTER Papel adesivo e parede. Foto:.lilianaporter.com 
observar que não existe uma transferência do trabalho gráfico da artista para o espaço expositivo e sim uma maneira de a artista perceber o mundo que se coloca em diferentes situações e lugares.

Johanna Drucker ${ }^{16}$ considera o território do livro uma "zona de atividade" propensa a intersecção entre disciplinas, campos e ideias. Acredito que isto se verifique de maneira clara em trabalhos como o de Edith Derdyk.

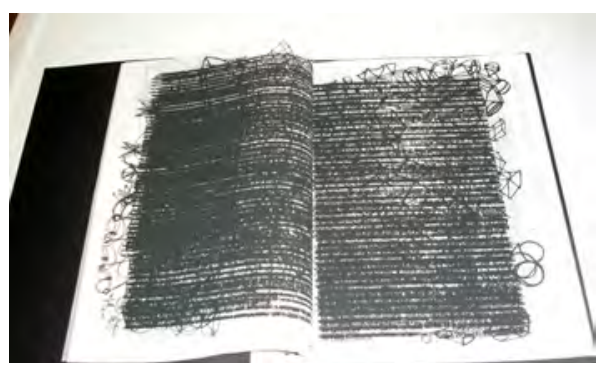

Cópia: Dia Um, 2010. Edith Derdyk. Impressão laser.

Trata-se de uma artista que circula tanto no campo dos livros de artista quanto das instalações. Em entrevista, ela me deixou algumas indicações do seu processo. Para Edith, o desenho é matriz e motriz do trabalho. Foi por meio dele que começou a tecer a grande colcha de retalhos que considera ser o seu trabalho. Ela se diz uma costureira, que tenta tecer algo através de desenhos, palavras e gestos. A artista conta que, em princípio, não eram livros de artista, mas cadernos de anotações que a acompanhavam por toda parte. Neles ela misturava desenhos e textos. Gostava de manipulá-los. Os cadernos a acompanhavam no processo de fatura de suas instalações. Neles, ela colocava anotações de textos referentes, esboços e todo o tipo de linha de pensamento. No trabalho de Edith existe uma busca pelo gesto. A ação do desenho. Ela busca captar ou transmitir de várias maneiras o gesto repetitivo, por meio dos fios. A performance do sujeito que desenha e do que observa ou folheia um livro. Um acúmulo de sobreposições que a artista diz tecer. Encontrou entre o transitivo e o transitório a ligação entre o livro e a instalação. Gostava de frequentar a biblioteca da FAU, perfeita mistura de arquitetura e livros. Edith sempre gostou de fazer livros. É autora de livros diversos: infantis, sobre o desenho, livros de poesia. Em seu processo de construção do livro já se colocava como artista mesmo sem saber na época tratarem-se de livros de artista. Edith foi uma das primeiras a ministrar um curso sobre livros de artista no Brasil. 


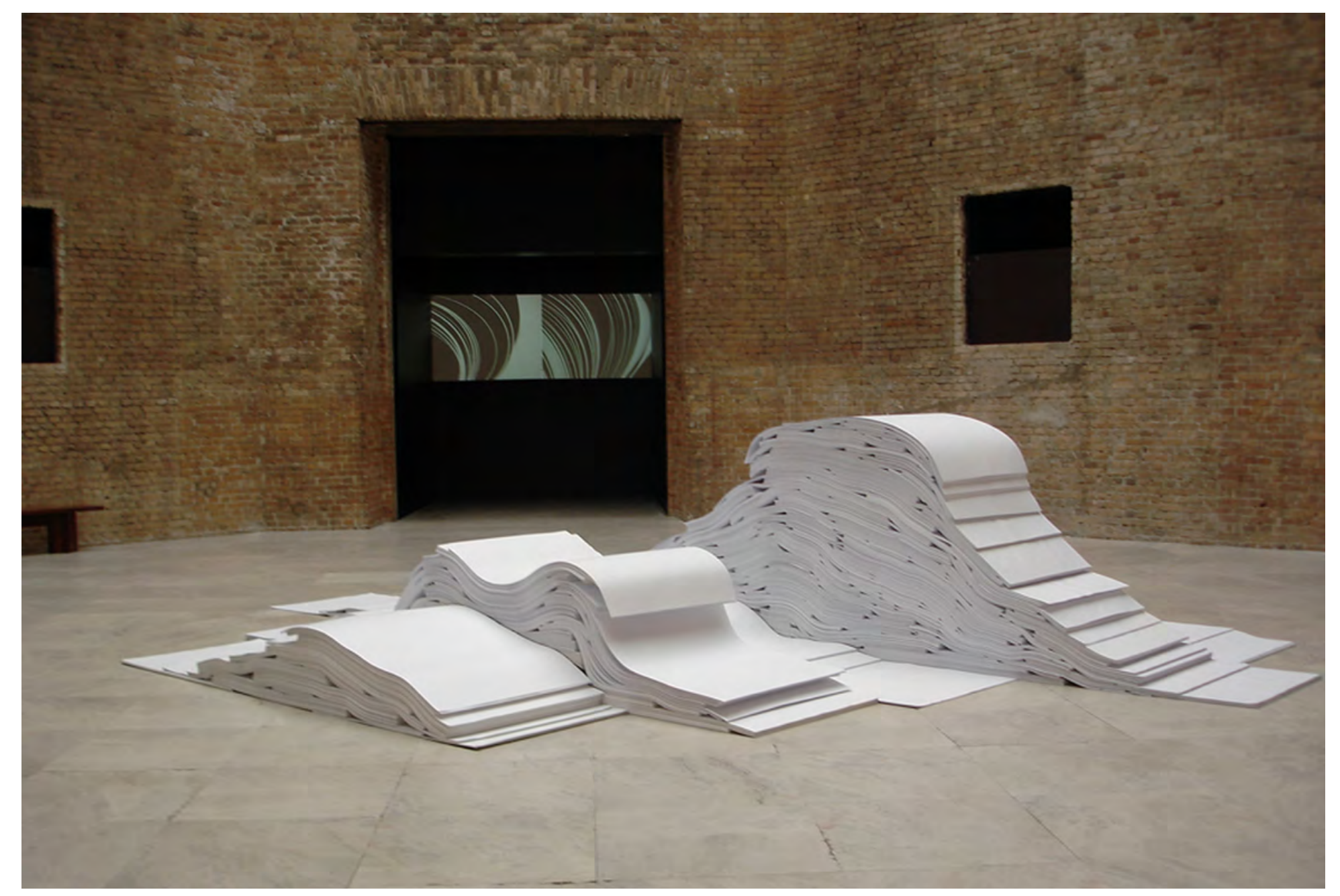

Onda Seca, 2007

EDITH DERDYK

Pilha de papel.

Foto:raimobenedetti.com 
Drucker identifica que, a partir dos anos 1980, surgiu uma série de trabalhos escultóricos que encaminhavam-se para a instalação e que tinham o livro como elemento motor. Ela considera que tais trabalhos, como o de Edith, localizam-se em uma região que vai além do livro de artista, e que pertencem mais à esfera da escultura e da instalação do que a dos livros. A autora chama isto de "Libricidade". É justamente isso que estamos afirmando até aqui. Acredito que nenhum dos artistas que citei tinha dúvidas de quando estavam produzindo livros ou instalações. Portanto, estamos apenas verificando que as relações entre as duas produções coexistem e se potencializam.

Essa chamada "Libricidade" citada por Drucker pode ser encontrada em minha instalação "Ponto de fuga" de 2012/2013. Produzida durante o período do mestrado e com a qual fui premiada no Programa Nascente da USP. Nela, o desenho produzido nas placas de acrílico e MDF caminham pela parede criando um percurso de uma placa a outra por onde o observador, para acompanhar a trajetória, deve caminhar pela sala, percorrendo também o percurso do desenho. As placas lembram páginas de livro, pelo modo como estão instaladas na parede. Enquanto o visitante caminha, é como se estivesse percorrendo as páginas. Esse trabalho foi produzido para um projeto no Espaço Intermeios para o qual a curadora Galciani Neves me convidou a

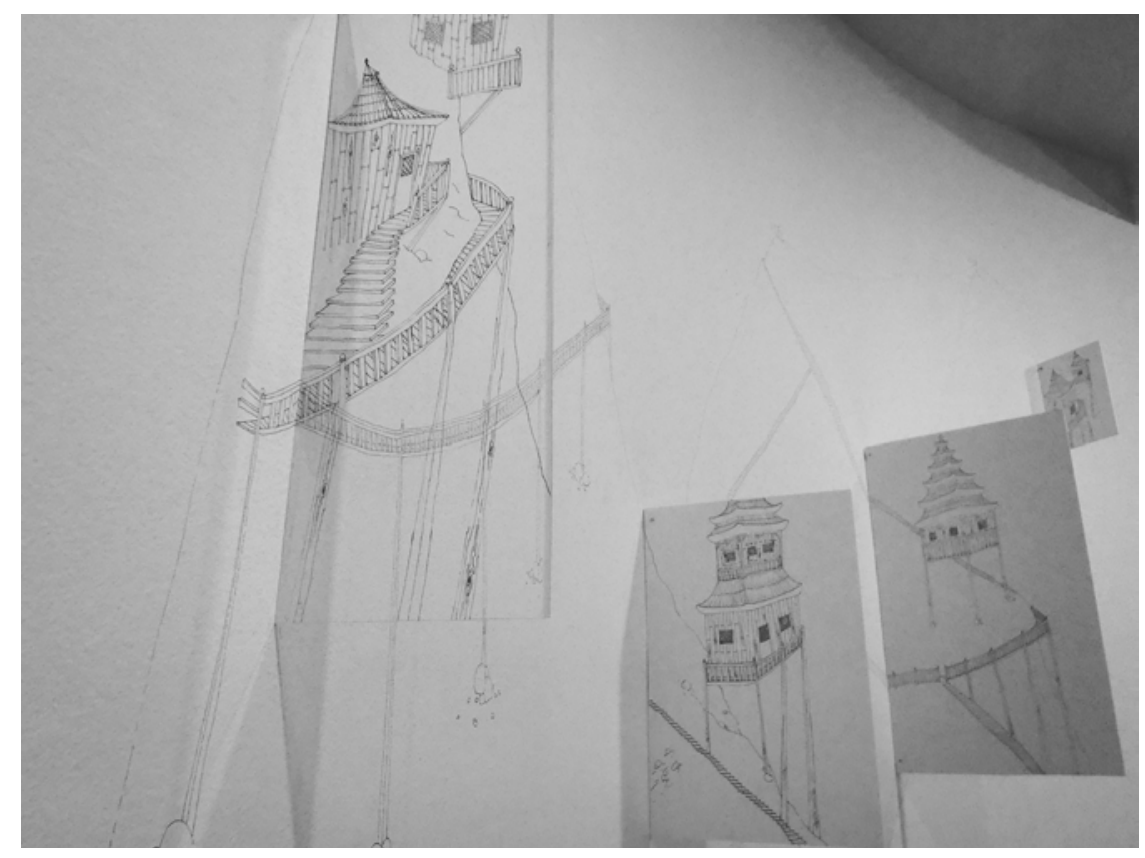

Ponto de Fuga, 2013

Desenho a caneta marcador e acrílica sobre placas de madeira, placas de acrílico translúcido e parede. $4.000 \mathrm{~cm}$ aproximadamente. 


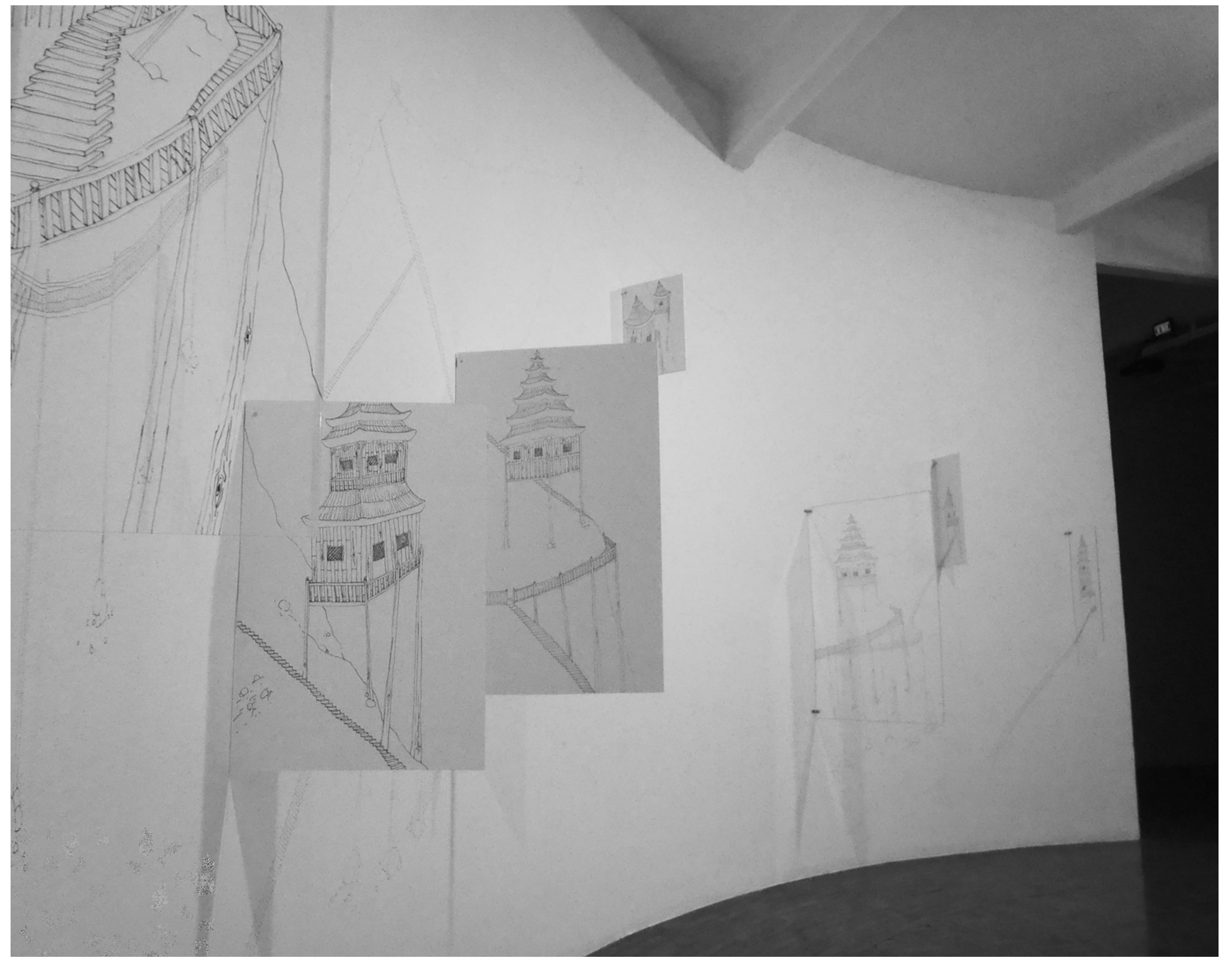




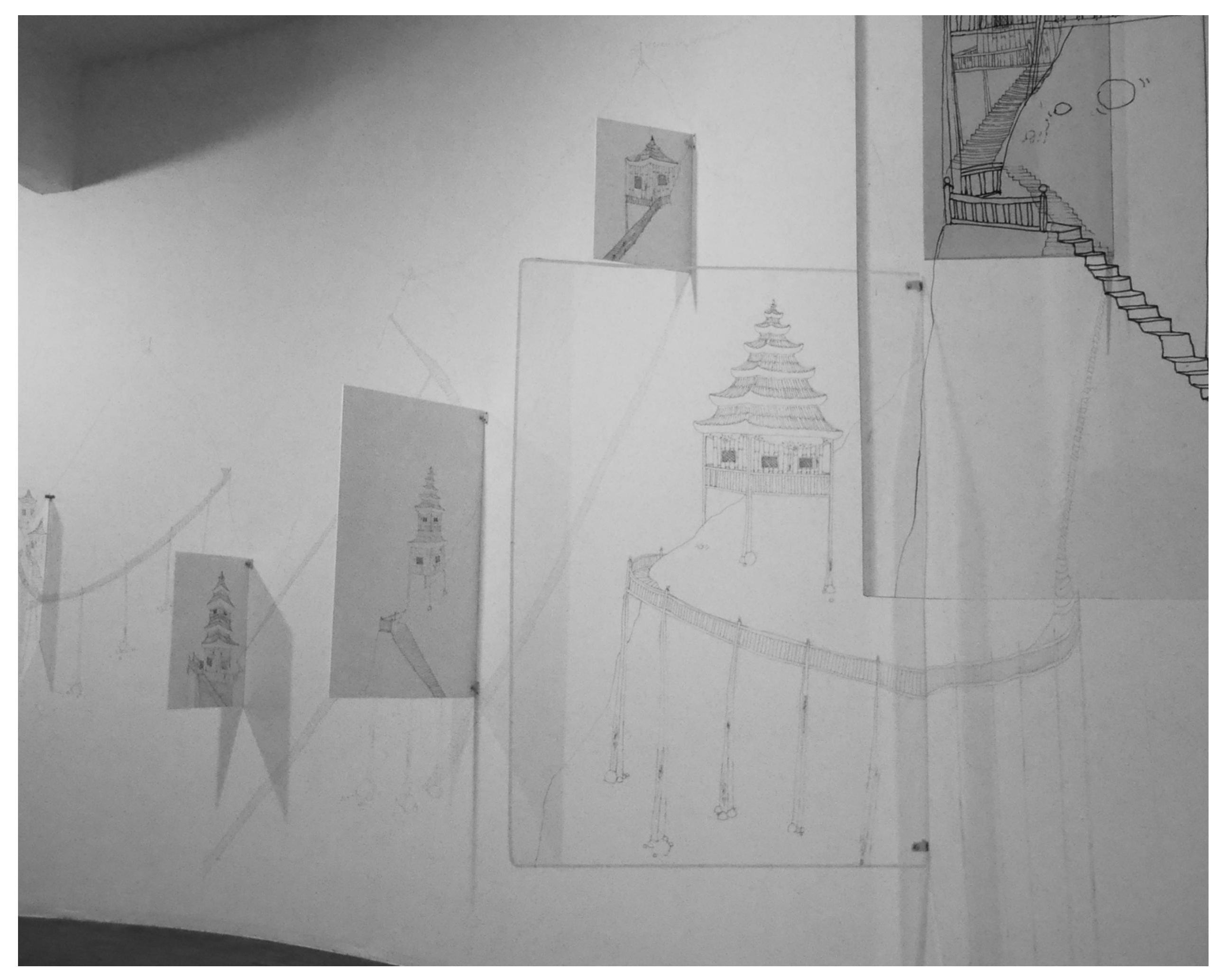


fazer uma intervenção em uma sala expositiva do local. Era uma sala de passagem, possuindo uma porta de entrada e uma saída que dava para dentro do espaço. Pensei neste trajeto como aquelas viagens míticas que algumas pessoas fazer e que ao retornarem dizem-se modificada. Pensei que, ao atravessar a sala e observar o trabalho a pessoa pudesse se sentir modificada também. O que haveria em uma viagem para que uma pessoa pudesse se sentir modificada? Geralmente quando as pessoas partem em uma viagem como estas, elas estão querendo abandonar alguma situação desagradável. Pensei nestes momentos como o ponto onde a pessoa quer fugir do seu cotidiano e, talvez, tal modificação venha apenas deste momento entre o trajeto até tais locais em que a pessoa pode refletir. Seriam o "Ponto de fuga" de onde, ao avistar tais paisagens magníficas, o que se avista é a si mesmo. E de onde, ao alcançar o local almejado, a única coisa a fazer é retornar. Porém, sentimos que ao retornar não somos os mesmos.

A segunda vez que apresentei essa instalação foi no Centro Universitário Maria Antonia, durante exposição do Programa Nascente da USP e foi interessante perceber como o trabalho se adequa e se modifica, dependendo do espaço onde é apresentado. Na segunda montagem, ele foi instalado em uma parede arredondada do espaço, o que proporcionou uma ampliação do trabalho, também por conta da altura da sala. As placas, como páginas soltas, foram instaladas em alturas e distâncias diferentes e o percurso do desenho entre elas foi criado no momento da fatura, percebendo qual a melhor maneira de alcançar a placa seguinte de maneira a compor com o desenho existente. Portanto, será uma instalação diferente a cada montagem. E, ao mesmo tempo, de fácil montagem e portabilidade, pois as placas não formam um volume muito grande. O que me leva a falar de uma outra característica das instalações que possuem uma estreita relação com a da produção dos livros de artista; o transitivo e o transitório. 
Muitos artistas contemporâneos são convidados a viajar e produzir trabalhos em espaços os mais diferentes possíveis. Muitas das vezes, estes trabalhos ficaram em tais espaços por um curto período e, em muitos dos casos, embora os artistas sejam convidados, os gestores dos espaços preferem não arcar com os custos de transporte dos trabalhos. Algumas vezes, também, o artista é convidado a fazer uma residência artística em local distante e produzir o trabalho no local. O resultado destas situações muitas vezes é a realização de trabalhos efêmeros. É o caso, por exemplo, da instalação "En Silencio" que Sandra Cinto produziu no espaço Matadero em Madri, em 2014. Sandra é uma artista reconhecida e é claro que o transporte de suas obras não seria questionado. Mas, imagina o transporte de obras suficientes para preencher um espaço gigantesco como o da Nave 16. Era preciso pensar uma estratégia. Diferentemente da instalação de Liliana Porter, em que a pilha de papéis era construída pela ação do público, a instalação "En Silencio" foi construída por papéis desenhados e amassados um a um pela artista e sua assistente. Em cima da mesa, ao lado da pilha, há um livro produzido pela artista com pautas

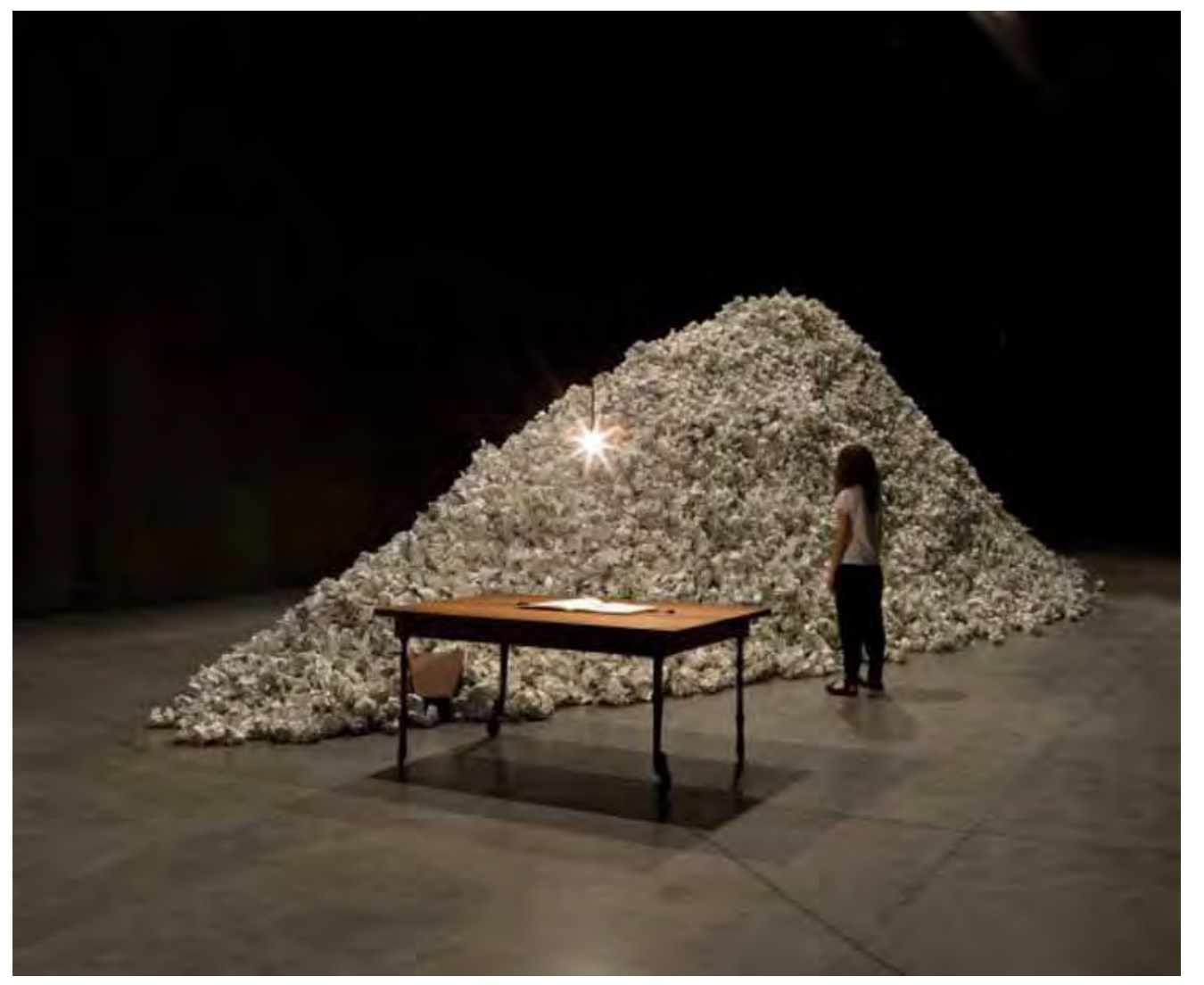

En Silencio, 2014

SANDRA CINTO

Pilha de papéis, mesa, livro e lâmpada.

Foto:flickr.com/ matadero Madri 
de música em branco e desenhos dela mesma dando a impressão de que navegam nos pentagramas. Neste trabaIno, existe o transitivo representado pelo livro de artista. Na portabilidade do livro a artista encontra o lugar perfeito para ser o campo de pouso das ideias do artista. O lugar onde ele as guarda para que de alguma maneira permaneçam. E na pilha de papel, efêmera, a representação do transitório. O próprio fato de a instalação ser produzida com uma pilha de papéis, do tipo que juntamos ao varrer antes de jogar no lixo. Também pode parecer que é um lixo que transbordou de tanto conteúdo. Coisa que depois será descartada. E por representar um momento do processo do artista que ninguém vê. $O$ da fatura do trabalho, com seus erros e momentos de solidão. A iluminação, além de ressaltar a dimensão da pilha de papéis, também alude ao instante da ideia por meio da única lâmpada.

Em 2007, fui convidada para realizar uma exposição na Galeria Léo Bahia Arte Contemporânea, em Belo Horizonte. O galerista havia visto minha instalação dos "Varais" no SESC Paulista e queria expor o mesmo trabalho. Além disto, para uma outra sala da galeria, me propôs fazer algum trabalho específico para lá. Os trabalhos deveriam ser leves para que eu pudesse levar na mala. Pensei então na situação de produzir um trabalho que ocupe um espaço, porém que em pouco tempo será desfeito. Me lembrou, então, a produção de uma festa de rua, em que todo mundo se empenha, enfeita a rua com bandeiras e tudo o mais para apenas alguns instantes de alegria. Logo tudo é desfeito, ficando apenas alguns resquícios de festa na paisagem, como algumas bandeiras enroscadas nos postes. Comecei então a produção de bandeirinhas de festa junina, todas brancas, em papel de seda. E, com o que sobrou das bandeiras, fiz vários balões pequenos. Pensei em forrar o teto da sala com as bandeiras e produzir um desenho a grafite na parede. Escolhi o grafite por ser um material que é possível apagar. Tem uma efemeridade inerente. Na verdade eu não tinha ideia do que iria desenhar. Pensei que no caminho até lá eu pensaria em algo. Enquanto estava no aeroporto uma mulher na fila de embarque dizia que gostava mais de Belo Horizonte do que 
São Paulo porque lá você olhava para o horizonte e pelo menos via um tanto de serrinha... Pronto, encontrei um título para o trabalho, "Festa na Serrinha". O desenho que produziria encontraria na paisagem vista do ônibus que leva do aeroporto até a cidade. Eram serras cortadas por cercas e torres de alta-tensão. 0 acúmulo de bandeirinhas produziu uma mudança na iluminação do espaço. Alguns balões pendiam das bandeirinhas, como se estivessem suspensos no ar. E o trabalho pousou ali por algum tempo. Como me disse a artista Edith Derdyk, seja no livro ou no espaço de uma sala, ambos são apenas lugares, campos de pouso para a obra que abrange tudo o que o artista faz.

Festa na Serrinha, 2007

Bandeirinhas em papel de seda, balões, barbante e desenho sobre parede.

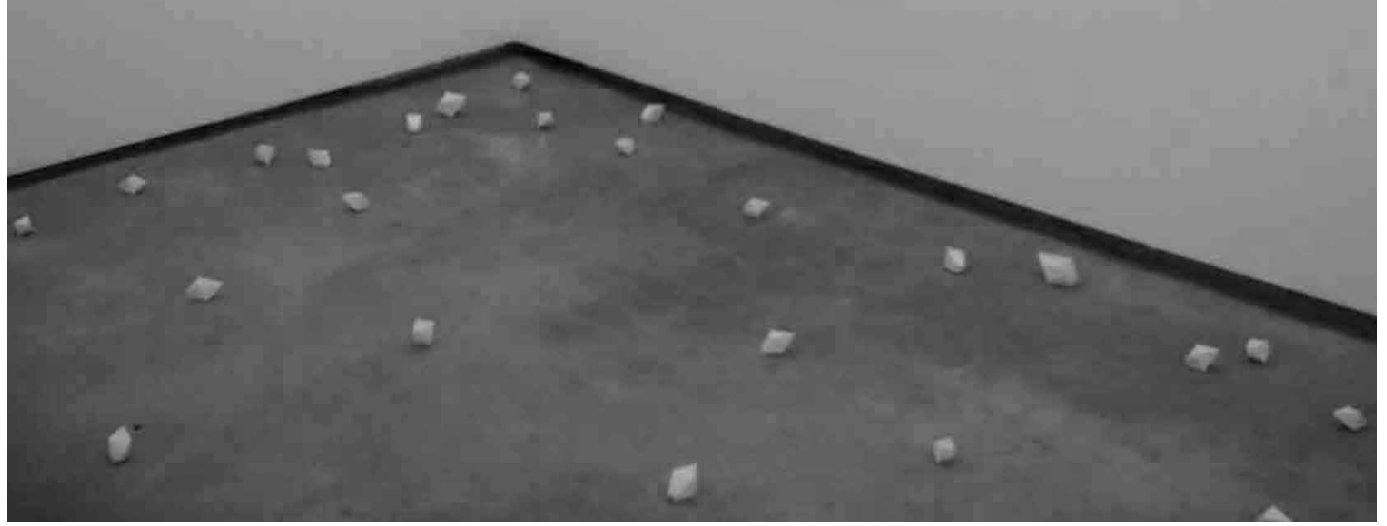





\section{Exposições Portáteis e O Campo de Pouso}

As relações entre o espaço do livro e o espaço onde ele é apresentado não podem ser ignoradas. Em uma mesa de feira, em uma exposição ou em uma livraria, apresentar o espaço do livro de artista constitui-se um desafio. Existe a problemática da manipulação, da conservação e forma de apresentação. Todas elas guiadas pela construção do objeto. O material e o formato de suas páginas relacionando-se e ativando o espaço expositivo. Há tempos os artistas têm explorado diferentes formas de apresentar seus trabalhos e as exposições portáteis, onde o artista apresenta suas obras em formato de mala ou caixas tem sido uma boa solução para trabalhos que estão sendo apresentados em pequenos formatos, mas que são representações de obras maiores, múltiplos ou simulacros. Acredito que tenham como referência os antigos caixeiros viajantes com suas malas repletas de coisas maravilhosas. A "Boîte-en-valise" de Duchamp, além de ser uma das mais conhecidas, também inspirou muitos outros artistas. Nela, o artista colocou miniaturas e reproduções de toda sua produção até aquele momento. Como em um mostruário de caixeiro viajante, a maleta funcionaria como um mini museu ou galeria, um espaço onde ele, de alguma maneira, conseguiria mostrar um trabalho que jamais ele conseguiria carregar em uma maleta.

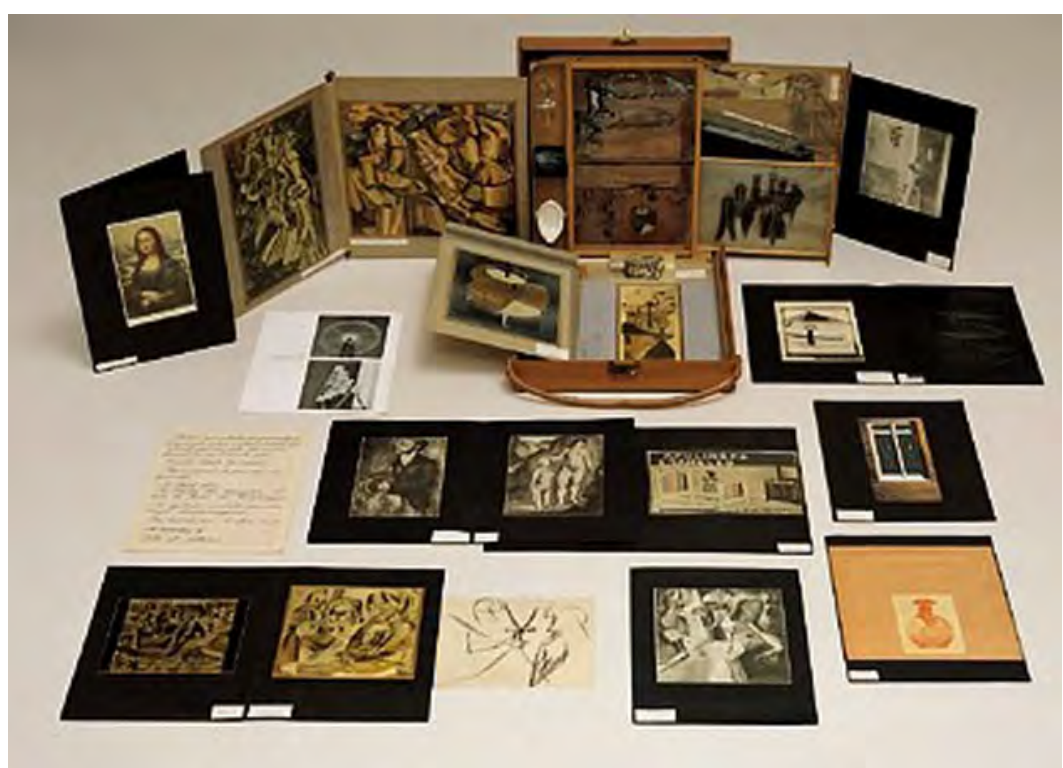

Boite-en-valise, 1935-41 MARCEL DUCHAMP Foto: moma.org 
Em "Arte Física: cordões/30 km de linha estendida" de 1969, Cildo Meireles nos apresenta de forma clara as relações de tempo e espaço contidas no trabalho, sendo na verdade o próprio assunto do trabalho. Tratasse de um registro de uma ação onde o artista percorre $30 \mathrm{~km}$ de trilha de terra no percurso onde hoje existe a rodovia Rio-Santos desenrolando um fio pelo caminho que, depois, retorna recolhendo o que sobrou dele. A obra se apresenta como velha caixa de madeira contendo um mapa do trecho norte do litoral carioca e um velho e esfiapado novelo de linha. A caixa é mais um elemento que ressalta o caráter transitório do trabalho. Além do próprio objeto mala já conter uma série de referências à transitoriedade, também existe a relação do espaço, 30 km cabendo em uma mala. Não se trata de um múltiplo, mas de um trabalho que também é um registro de ação.

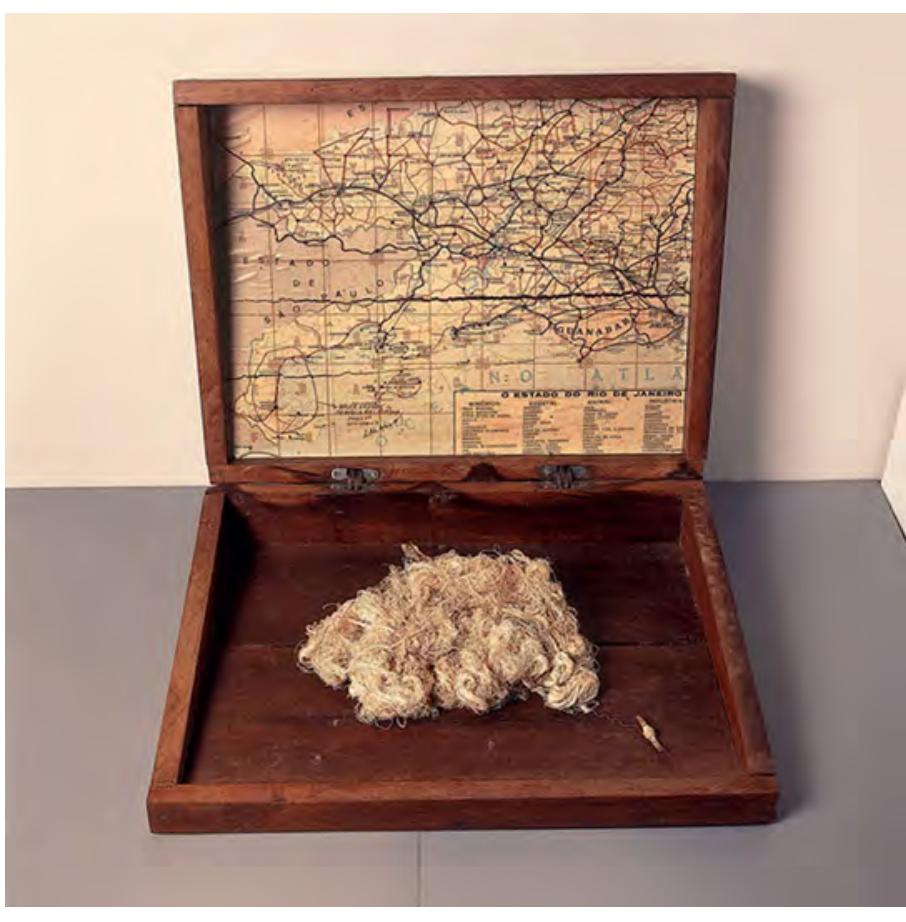

Arte Física: Cordões/ 30 km de linha estendida, 1969 CILDO MEIRELES

Linha industrial, mapa, caixa de madeira $60 \times 40 \times 8 \mathrm{~cm}$

foto: revistapesquisa.fapesp.br 


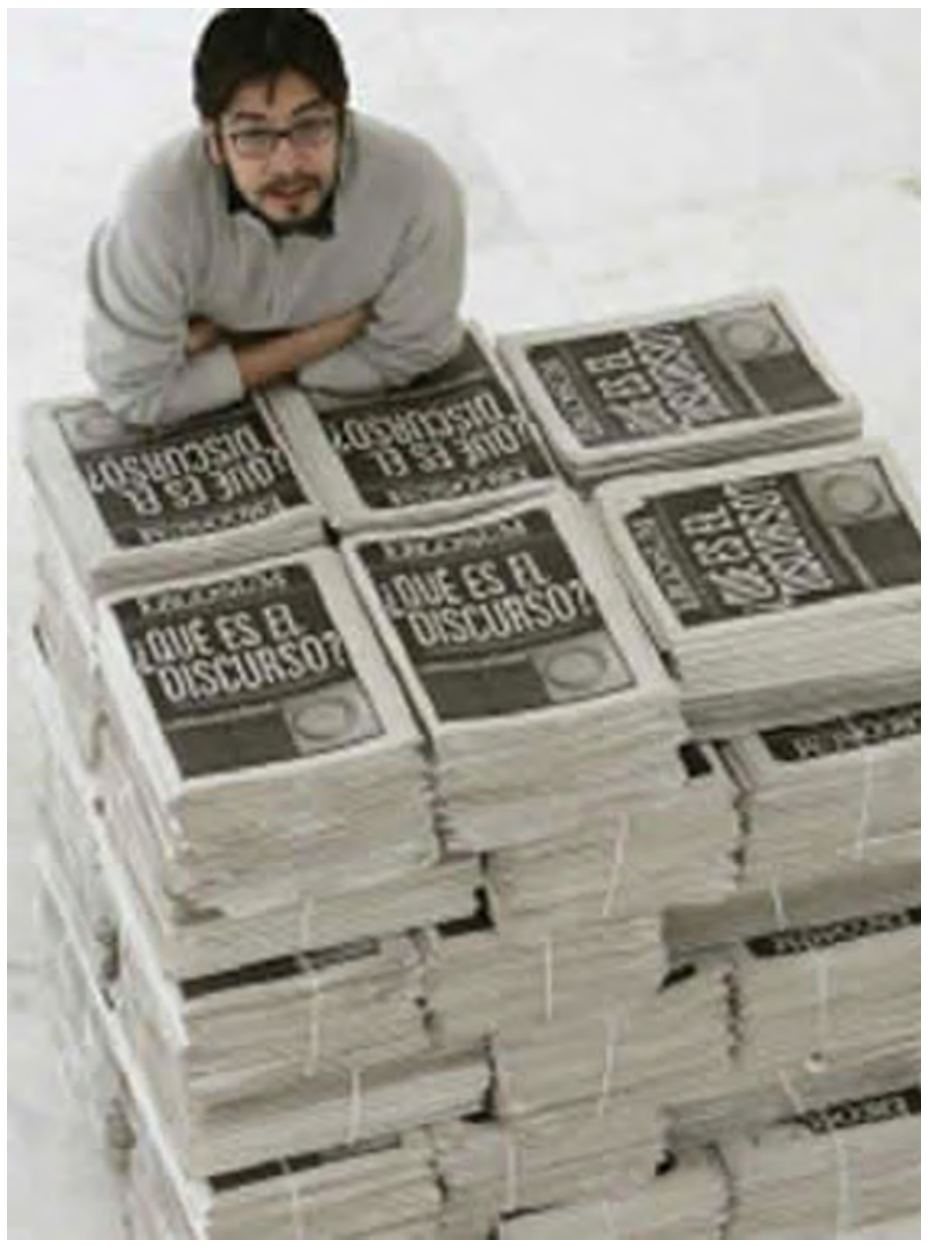

Ergo Sum, 2007

ERICK BELTRÁN

Impressão offset sobre papel jornal. 39 X $31 \mathrm{~cm}$. (Fechado)

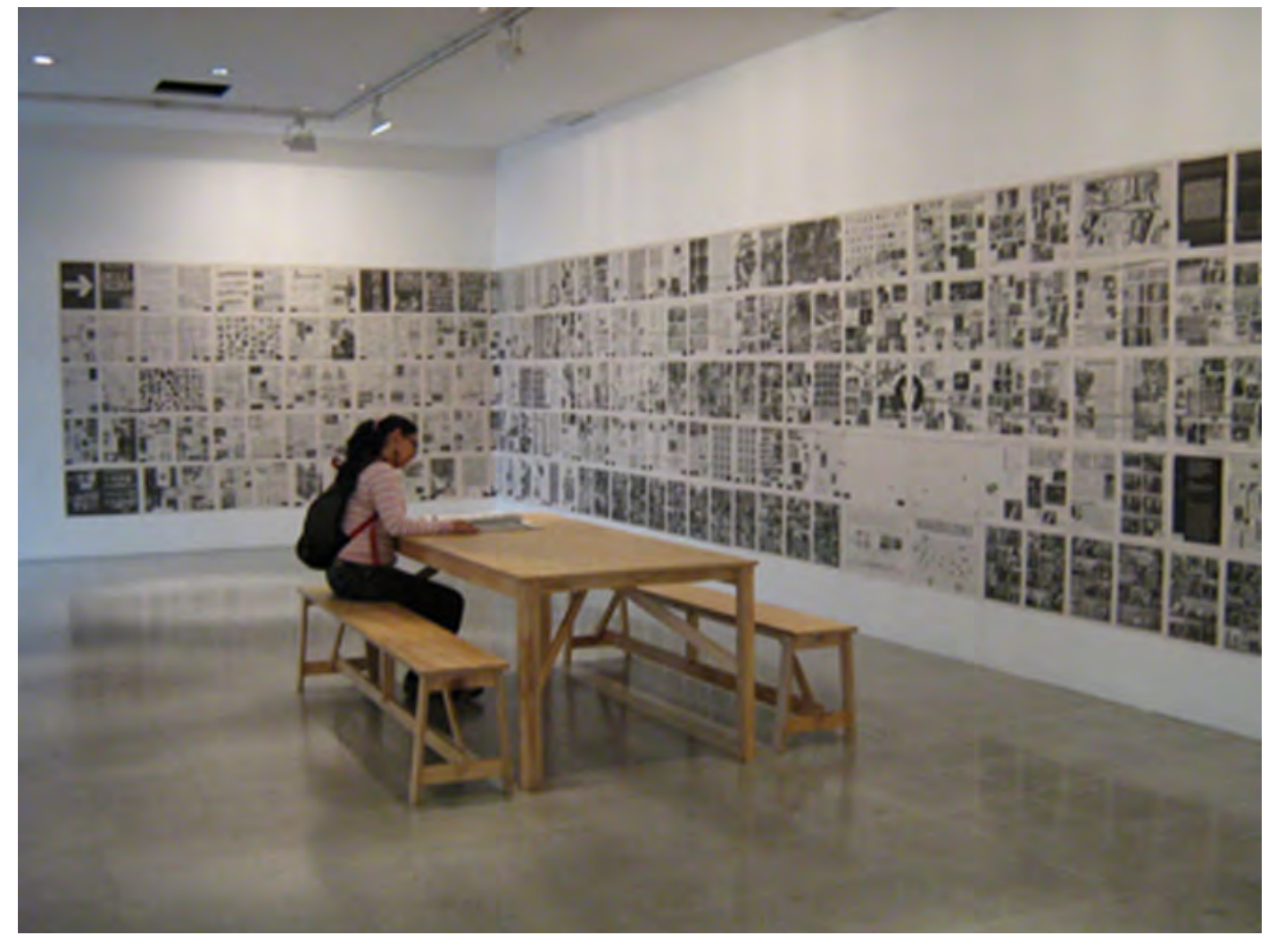

Vista de Ergo Sum Instalado na parede. Foto: m3lab.info e eluniversal.com.mx 
Nem sempre este trabalho virá de caixa ou maleta. Ele pode, por exemplo assumir o formato de um jornal, como na obra "Ergo Sun" do artista mexicano Erick Beltrán. Um jornal que tem instruções nas bordas e que, ao montarmos, se transforma em uma instalação. É um trabalho que funciona enquanto publicação e também enquanto potencial de expansão.

O marchand americano Seth Siegelaub, no final dos anos 1960, em meio a uma enorme difusão de galerias em Nova lorque, talvez como numa espécie de contracorrente, fecha suas portas e estabelece-se na sala de seu próprio apartamento, fundando o que ele acreditava ser um verdadeiro espaço expositivo comunicacional, um local para debates e interlocuções, contatos e difusão de ideias.

No Brasil, um projeto nesse sentido vem sendo desenvolvido na Universidade Federal de Santa Catarina pela Profa. Regina Melin com o projeto "Exposições Portáteis" como dispositivo curatorial. O projeto, além de propor a execução de publicações coletivas como forma de exposição, também pretende promover a circulação dessas exposições com o menor número de equipamentos possíveis. Apenas parede, uma mesa e cadeiras para possibilitar a reunião de grupos a fim de debater a respeito do projeto. Além do projeto "PF", ou "Por Fazer", Regina Melin também criou sua própria editora, a "Parêntesis", a fim de editar as publicações de artistas convidados e dos projetos que cria. Com esta editora ela participa de feiras de publicações independentes onde torna acessível os trabalhos realizados em seus projetos. 
Uma iniciativa de publicação coletiva é um projeto do Designer Guilherme Falcão. Ele convidou alguns artistas para participar de uma publicação intitulada "Zine Parasita". O mais interessante deste projeto foi a forma que ele encontrou para disponibilizá-lo ao público. Ele distribuía o "Zine" colocando-o no meio das páginas dos livros à venda em livrarias, ou de livros de biblioteca. Portanto o "Zine" parasitava outras publicações. É gratuito, mas você precisa encontrá-lo. Guilherme também criou uma editora, a "Contra" e publica trabalhos de vários artistas. Participei de uma publicação coletiva a convite dele em 2013. Foi um desafio para mim, pois estou acostumada a criar o livro todo e não a ocupar somente duas páginas como era o projeto. Duas páginas para cada artista. Queria produzir algo que, de alguma maneira, relacionasse as duas páginas. Pensei em ações e reações. Como no filme "Magnólia", em que uma ação de uma pessoa pode produzir uma reação a quilômetros de distância. Como se a ação de abrir uma página pudesse produzir um terremoto. A potência do movimento de abertura do livro produzindo um terremoto em uma biblioteca e fazendo com que todos os livros da prateleira viessem ao chão. Produzi então uma prateleira em cada página de modo a interagir também com o trabalho de um outro artista, Simon Fernandes que havia pensado em um trabalho para ser recortado. Pensei em envolver o trabalho dele com as minhas prateleiras, de modo que se a pessoa recortar o trabalho dele minhas páginas se unem e se transformam no corredor de prateleiras da biblioteca depois do terremoto.

Guilherme é um dos muitos editores e artistas que participam das feiras de publicações que surgiram aqui no Brasil há alguns anos . O interessante destas feiras é a possibilidade de o próprio artista ou editor entrar em contato direto com o público e perceber qual a aceitação do trabalho que está produzindo. Ouvir opiniões, trocar informações com outros expositores etambém de tornaracessíveis os seus trabalhos. Amesa funciona como uma exposição. Porém, os trabalhos podem ser manipulados e adquiridos. Uma questão importante das edições é possibilitar a manipulação do trabalho sem o receio de que ele venha a ser destruído. O que acontece, geralmente, quando o livro ou o trabalho é único. Porque existe mesmo um desgaste pelo excesso de manipulação. Com a edição fica também assegurado que a obra sobreviva. 


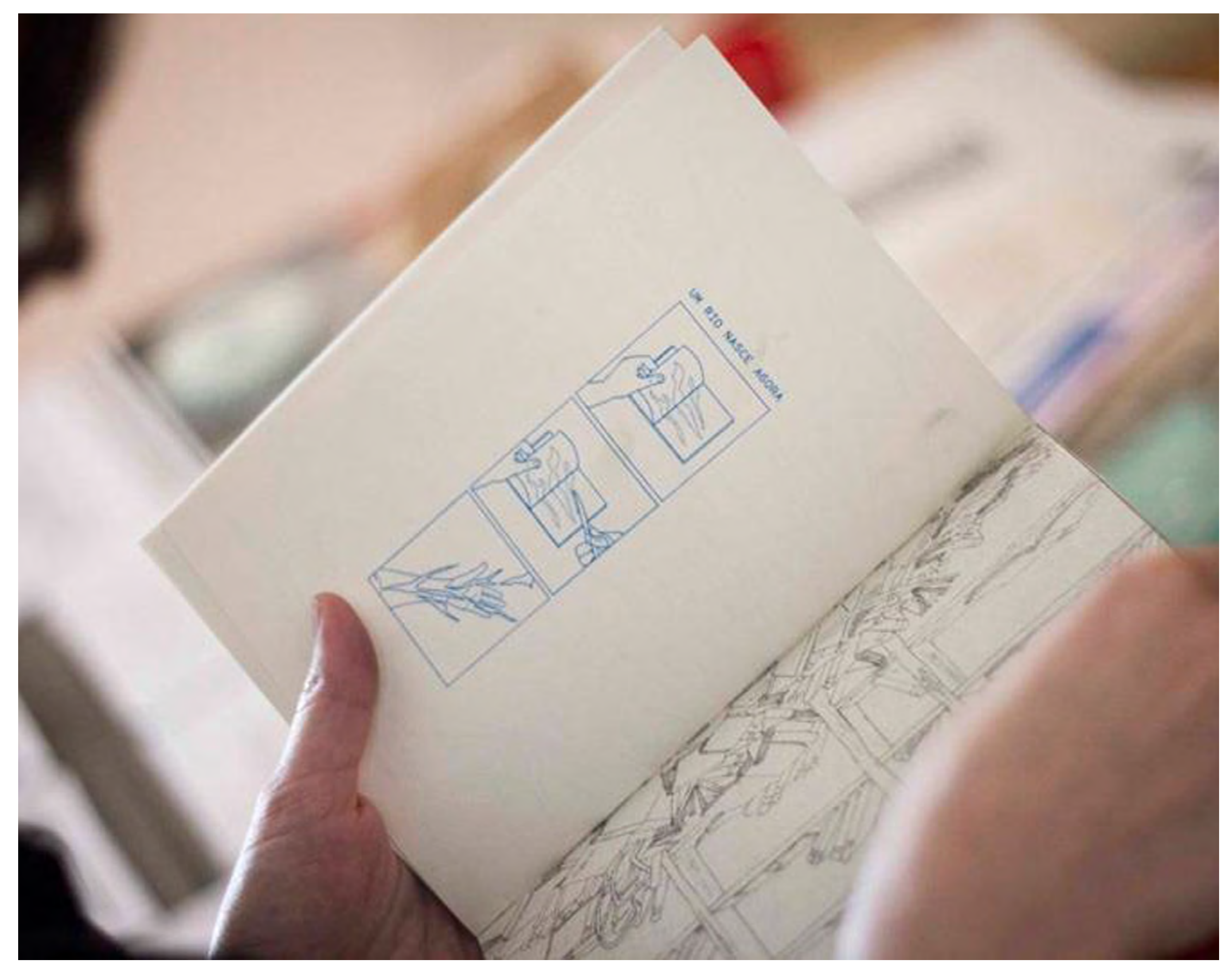




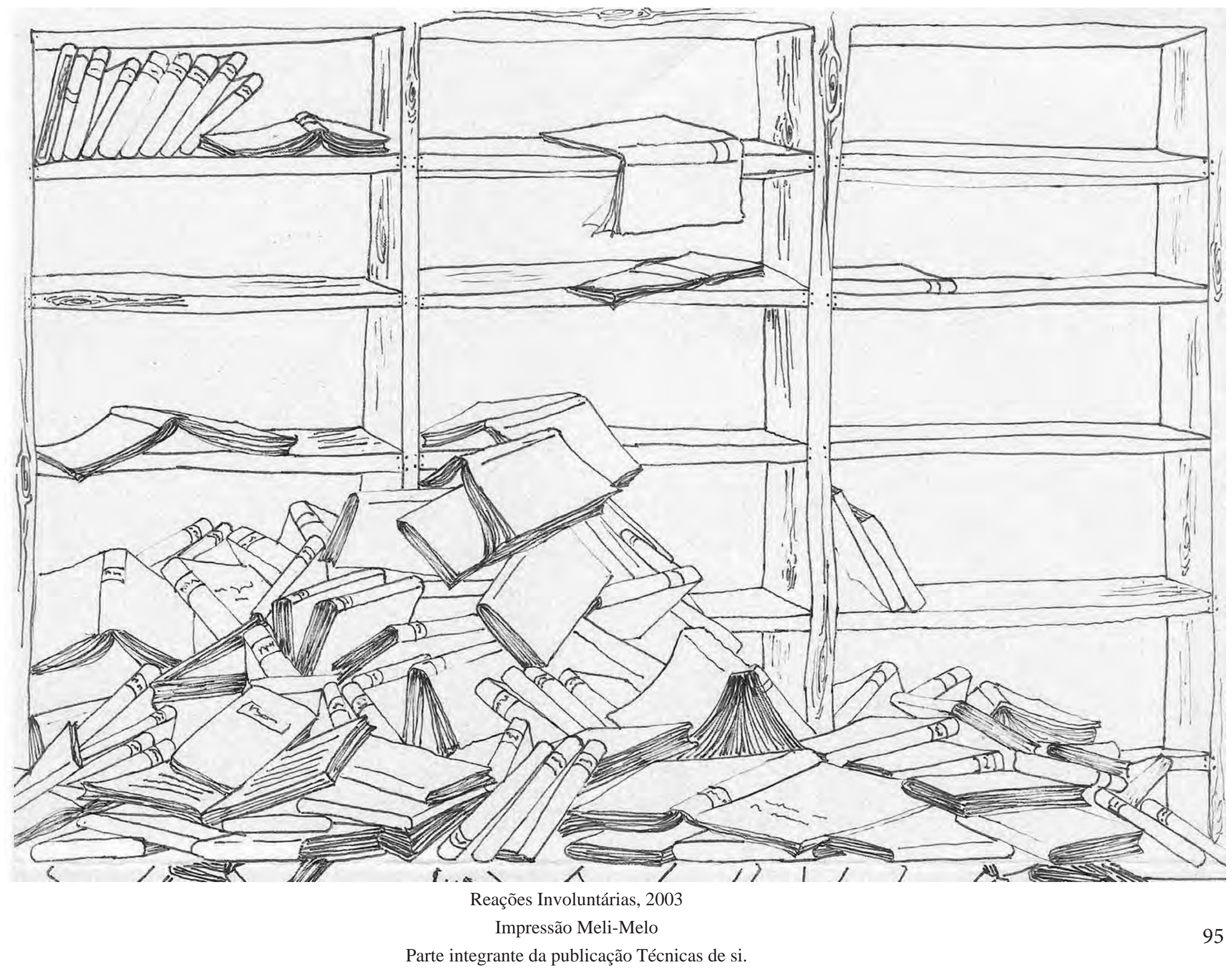


Guilherme é um dos muitos editores e artistas que participam das feiras de publicações que surgiram aqui no Brasil há alguns anos . O interessante destas feiras é a possibilidade de o próprio artista ou editor entrar em contato direto com o público e perceber qual a aceitação do trabalho que está produzindo. Ouvir opiniões, trocar informações com outros expositores etambém de tornar acessíveis os seus trabalhos. Amesa funciona como uma exposição. Porém, os trabalhos podem ser manipulados e adquiridos. Uma questão importante das edições é possibilitar a manipulação do trabalho sem o receio de que ele venha a ser destruído. O que acontece, geralmente, quando o livro ou o trabalho é único. Porque existe mesmo um desgaste pelo excesso de manipulação. Com a edição fica também assegurado que a obra sobreviva.

Outra proposta brasileira neste sentido é o "Projeto Múltiplo" da curadora Paula Borghi. O projeto funciona como um acervo móvel que vai sendo construído sempre que ela o disponibiliza ao público em forma de exposições itinerantes. A curadora promove chamadas para envios de publicações durante as mostras. Sendo assim, qualquer interessado pode fazer parte do acervo, contanto que tenha um trabalho com tiragem mínima de 10 exemplares. Em 2014, durante o período do mestrado fui convidada por ela para participar de um outro projeto intitulado "Lambes na Laje". O projeto consistia em convidar artistas para uma exposição relâmpago de apenas um dia em que os trabalhos deveriam ter formato de Lambe-lambe, isto é, que pudessem ser grudados na parede. Na ocasião, os artistas podiam comercializar os trabalhos que realizassem por um preço baixo. Uma forma de tornar uma parte da produção do artista acessível. Eu participei do projeto na sua terceira edição, que aconteceu no espaço da Red Bull Station, no centro de São Paulo. Produzi um trabalho especialmente para a ocasião, já que não poderia participar com livros. Pensei em como poderia, dentro da proposta, realizar algo que fosse realmente significativo dentro da minha produção, posto que a estampa por si só não faz parte do meu repertório. Busquei como referência os primeiros desenhos que fazia, nos quais eu colava folhas de papel sulfite uma na outra para fazer com que o desenho caminhasse por elas. Dei o título 
de "Kafkante" em homenagem ao "Castelo" do Kafka e, também como um sinal de que aquilo seria uma parcela de um desenho sem fim. Inatingível. Produzi as impressões em serigrafia e as imagens só poderiam ser vendidas em conjunto. Ao unir as 6 páginas de desenho, o resultado era um desenho grande que funcionava quase como uma instalação.

Nos últimos anos, o meio de publicações tem crescido bastante e a possibilidade de o artista fazer circular suas obras sem necessariamente estar vinculado ao grande mercado de arte foi muito facilitada com os novos meios de comunicação e o surgimento de feiras especializadas. Acredito que caberá somente ao público que as consome pesquisar e perceber o que tem valor de arte e o que é apenas o fanzine de um adolescente querendo desenhar. Tudo é válido. Porém, nem tudo quer ser arte. Muitas vezes, a produção de múltiplos é apenas uma amostragem da produção do artista, como na "Boîte" de Duchamp. Porém, é uma parte que o artista está tornando acessível ao grande público, de alguma maneira. Seja por meio de uma editora ou por uma edição produzida pelo próprio artista. Muitas vezes essas edições são a única forma de o artista tornar pública a sua obra. Portanto, acredito que elas são de suma importância para trazer ao conhecimento do público uma produção que vem acontecendo para além das galerias e museus de arte.

Não por acaso escolhi o formato de uma maleta para entregar minha dissertação de mestrado. Dentro dela, além de minha dissertação disponibilizo para os membros da banca o conjunto de publicações que realizei durante o período do mestrado. Penso que desta maneira realizo uma pequena exposição individual, portátil e que de alguma maneira terá uma duração maior do que o período do calendário de um espaço expositivo convencional, visto que estará disponível para vocês apresentarem-na onde e quando bem entenderem. 

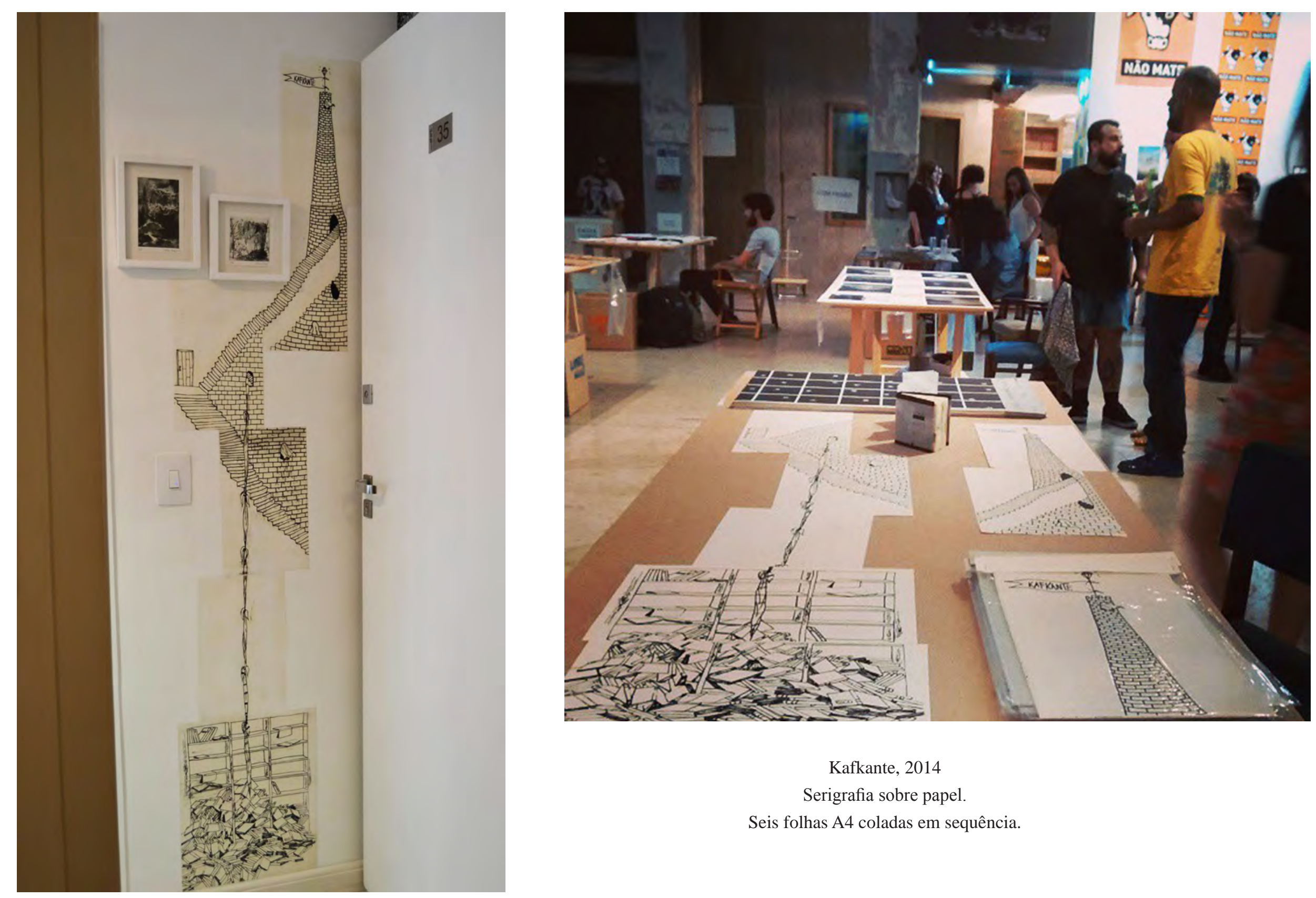

Kafkante, 2014

Serigrafia sobre papel.

Seis folhas A4 coladas em sequência. 
“...o que me parece essencial ao livro de artista (e por isso tem esse nome) é que o artista exerce total responsabilidade sobre o livro, da concepção à realização e, às vezes, à divulgação. Ele tem o domínio total sobre tudo (mesmo que não o fabrique com suas próprias mãos) justamente porque o livro é uma obra no sentido pleno do termo, ou seja, é concebido de tal maneira que todos os aspectos do livro participam da significação. O livro não é aí um simples continente ou suporte para uma mensagem que seria independente dele, como é o caso dos livros de literatura ou dos livros em geral"15 


\section{Considerações finais}

Ao final desta dissertação, concluo que o espaço do livro de artista é um espaço muito propício ao diálogo interdisciplinar, por isso, acaba proporcionando maior liberdade e abrindo-se à experimentação. Embora artistas acostumados com outros meios também possam produzir livros de artista, o que acontece é que nem todos que transitam por este espaço o percebem como tal. Podemos identificar como esta sendo a problemática do grande volume de publicações produzidas na atualidade. É preciso relacionar-se com o espaço do livro tal qual o artista que ocupa um espaço expositivo de uma sala. Não é possível, hoje em dia, ignorar o espaço onde se instala sua obra, mesmo que não seja um trabalho de instalação. Quando o artista se apropria do espaço como mais um elemento de construção de sua obra, o trabalho ganha um potência. Os artistas e trabalhos citados nesta dissertação são os que tomo como exemplo de construções bem feitas entre o espaço e a obra. Se é que existem tais diferenças entre o espaço e a obra, quando o jogo da construção é bem executado.

A narrativa bem construída depende do bom uso da materialidade tanto no livro como fora dele. É preciso perceber que tudo na obra comunica. A pluralidade de meios para a produção de arte contemporânea deve ser explorada, portanto cabe ao artista perceber qual é o melhor meio para realizar o seu projeto. Seja uma ação que posteriormente exista apenas nas memórias de uma caixa velha e um bolo de linha, seja em uma publicação de registros de ações, o artista não pode ignorar que, ao produzir tais objetos ou publicações, está gerando um novo trabalho. Mais camadas podem ser agregadas ao registro de uma ação que passa a ser uma publicação. É preciso pensar a ação dentro do espaço do livro. O movimento de abrir e fechar. O modo como a publicação irá se configurar quando aberta. $O$ tipo de capa. A textura e materiais das páginas. Tudo comunica. E quem entende estes mecanismos comunica melhor. 
Percebo cada vez mais que existe um diálogo entre a construção do livro de artista com o trabalho instalativo para quem lida com os dois campos. E pode existir também com outras relações duplas. Com um artista que faz performance e produz livros, por exemplo, enfim, que faça uso de mais de uma mídia. Acredito que o artista deva explorar as possibilidades de territórios por onde pode circular. O que é preciso, sim, é utilizar bem o espaço que se pretende. Tanto o do livro como qualquer outro. Procurar perceber o veículo que está sendo utilizado para essa comunicação.

Construir um livro de artista não é o mesmo que produzir um caderno de rascunho. Entendo que, ao experimentar uma ideia no espaço do livro, já existe um espaço sendo ocupado. Um espaço que possui especificidades que devem ser levadas em conta. Muitas vezes, determinada ideia está ali por impossibilidade de estar em um espaço ideal. $\mathrm{E}$ isso não deve ser considerado uma perda. A partir de um ideal de obra, ao ocupar um livro já estamos construindo uma outra obra. Esta obra pode até conter resquícios da ideia anterior, mas já é um outro trabalho. Vemos muitas vezes artistas perseguindo uma ideia de trabalho e não percebendo o que acontece no decorrer do processo de construção. Muitas obras deixam de ser produzidas por uma falta de percepção do processo de construção. Durante este processo, muito do trabalho é melhor compreendido e muitos outros são criados em decorrência do processo. Mesmo que seja de um trabalho que, no momento acreditemos que "não deu certo".

Finalizo este texto e o período do mestrado percebendo que, na impossibilidade de construir trabalhos instalativos, eu acabei produzindo uma grande quantidade de publicações. Percebo que o importante mesmo é que o trabalho exista. Que continue, posto que tudo o que o artista faz é parte de um todo, que é o verdadeiro trabalho. A pesquisa. Portanto o importante é continuar no caminho. E a estrada vai sendo construída e não se sabe onde vai dar. 


\section{Bibliografia:}

ANTÓN, José Emilio. El libro de artista, el libro como obra (Catálogo de exposición). Munique: Instituto

Cervantes de Munique, 1994.

ARNHEIN, Rudolf. New essays on the psychology of art. Berkeley: University of California Press, 1986. p. 202.

BACHELARD, Gaston. A poética do espaço. São Paulo: Martins Fontes, 2008. pag. 202.

BOURRIAUD, Nicolas. Estética relacional. São Paulo: Martins fontes , 2009

CAMPOS, Augusto de; PLAZA, Julio. Poemóbiles. Editora Brasiliense, 1984.

CARRION, Ulises. "El arte nueva de hacer libros". In: El arte de los libros de artista. Madri/ Nova York: Turner/ Distributed Art Publishers, 2003.

CARRIÓN, Ulises. A nova arte de fazer livros. Tradução de Amir Brito Cadôr. Belo Horizonte: Cl Arte, 2011.

CAUQUELIN, Anne. A Invenção da Paisagem, Martins Fontes, 2007

COCCHIARALE, Fernando. Lygia Pape: entre o olho e o espírito. Porto: Minesis, 2004. pag. 19.

DEBRET, Jean-Baptiste. Caderno de Viagem [Texto e organização Julio Bandeira]. São Paulo: GMT, 2006.

DERDYK, Edith. Entre Ser Um e Ser Mil. O Objeto Livro e suas Poéticas. Editora Senac, 2013.

DERDYK, Edith. Linha de Horizonte: por uma poética do ato criador. São Paulo: Intermeios/Casa de Artes e Livros, 2012. 
DIDI-HUBERMAN, Georges. O que vemos, o que nos olha [Tradução de Paulo Neves]. São Paulo: 34, 2010. pag. 87/89.

ECO, Umberto. Obra Aberta. São Paulo: Perspectiva, 1991.

FABRIS, Annateresa; TEIXEIRA DA COSTA, Cacilda. Tendências do livro de artista no Brasil. São Paulo: Centro Cultural São Paulo, 1985.

VENÂNCIO FILHO, Paulo. Marcel Duchamp: a beleza da indiferença. Brasiliense, 1986.

FLUSSER, Vilém. O mundo codificado: por uma filosofia do design e da comunicação. São Paulo: Cosac Naify, 2007.

FULTON, Hamish. Ajawaan. Toronto: Art Metropole, 1987

GREAVES, Tom. Heidegger / Tom Greaves [tradução e revisão técnica: Edgar da Rocha Marques]. Porto Alegre: Penso, 2012.

KRAUSS. R. “A escultura no campo ampliado”. In: Revista Gávea. Rio de Janeiro: PUC, ano 1, no1, 1984

LIPPARD, Lucy R. Seis años: la desmaterialización del objeto artístico de 1966 a 1972 . Madri: Akal/ Arte Contemporánea, 2004.

MELIN, Regina. Outros espaços expositivos. Revista DaPesquisa, Florianóplis, v.2, n.2, ago. 2006. Disponível em [www.ceart. udesc.br/revista_dapesquisa/volume2/plasticas/regina\%20Melin.pdf]

MILES, M.; HALL, T (eds.). Interventions:advances in art and urban futures, vol. 4. Portoland: Intellect Books, 2005

MUNARI, Bruno. Fantasia. Lisboa: Edições 70, 2007.

NEVES, Galciani. Tramas comunicacionais e procedimentos de criação: por uma gramática do livro de artista. São Paulo, Puc-SP, 2009. 
O'DOHERTY, Brian; MCEVILLEY, Thomas. No interior do cubo branco: a ideologia do espaço da arte. São Paulo: Martins Fontes, 2002.

PAZ, Octavio. Marcel Duchamp ou o castelo da pureza. São Paulo: Perspectiva, 2014. pag. 23.

LAMBOTTE, M-C. Estética da melancolia. Rio de Janeiro: Conpanhia de Freud, 2000.

Plaza. Julio. "O livro como forma de arte (I)". Arte em São Paulo. São Paulo, n. 6, abr., 1982.

Pós: Belo Horizonte, v. 2, n. 3, p. 137 - mai. 2012.

ROLNIK, Suely (org.). Lygia Clark: da obra ao acontecimento. Pinacoteca do Estado, 2006.

SILVEIRA, Paulo. A crítica e o livro de artista. Pós, v. 2, n.3. UFMG. Maio, 2012.

SILVEIRA, Paulo. A Página Violada: da ternura a injúria na construção do livro de artista. Porto Alegre: UFRGS, 2001.

VENEROSO, Maria do Carmo de Freitas. "Perspectivas do livro de artista: um relato”. Pós, V. 2, n.3, maio 2012.

ZÓZIMO da Rocha, Michel. Estratégias expansivas, publicações de artistas e seus espaços moventes. Porto Alegre: FUNARTE, 2011. 